\title{
Estimating Default Probabilities of Emerging Market Sovereigns: A New Look at a Not-So-New Literature
}

\author{
Marcel Peter \\ Graduate Institute of International Studies
}

\begin{abstract}
The January 2001 proposal for a New Basel Capital Accord has renewed the interest in obtaining default probabilities for various types of borrowers. This paper uses a panel logit model to estimate default probabilities of 78 emerging market countries (1984-97) as a function of a set of economic and political variables. These sovereign default probabilities are then compared with the default rates associated with the sovereign credit ratings of the two major rating agencies, Moody's Investors Service and Standard \& Poor's. Unlike the existing literature, we define the dependent variable ("sovereign default") differently, using the changes in the levels of debt arrears and amounts rescheduled as criteria instead of the levels themselves. The paper finds, first, that the most important determinants of sovereign default appear to be the past repayment performance of a country, the cost of international credit, the volatility of per capita income, political risk, and exchange rate misalignments. Second, the comparison of estimated default probabilities with rating agencies' default rates shows that the latter seem to considerably underestimate sovereign default risk. In other words, sovereign credit ratings appear to be too high on average.
\end{abstract}

(C) The Author.

All rights reserved. No part of this paper may be reproduced without the permission of the author. 


\title{
Estimating Default Probabilities of Emerging Market Sovereigns: A New Look at a Not-So-New Literature*
}

\author{
Marcel Peter \# \\ Graduate Institute of International Studies, Geneva
}

First version: November 2000

This version: April 2002

\begin{abstract}
The January 2001 proposal for a New Basel Capital Accord has renewed the interest in obtaining default probabilities for various types of borrowers. This paper uses a panel logit model to estimate default probabilities of 78 emerging market countries (1984-97) as a function of a set of economic and political variables. These sovereign default probabilities are then compared with the default rates associated with the sovereign credit ratings of the two major rating agencies, Moody's Investors Service and Standard \& Poor's. Unlike the existing literature, we define the dependent variable ("sovereign default") differently, using the changes in the levels of debt arrears and amounts rescheduled as criteria instead of the levels themselves. The paper finds, first, that the most important determinants of sovereign default appear to be the past repayment performance of a country, the cost of international credit, the volatility of per capita income, political risk, and exchange rate misalignments. Second, the comparison of estimated default probabilities with rating agencies' default rates shows that the latter seem to considerably underestimate sovereign default risk. In other words, sovereign credit ratings appear to be too high on average.
\end{abstract}

Keywords: default rate, determinant, rating agency, sovereign credit rating, sovereign default probability

JEL Classification: F32, F34, G15, G21

\footnotetext{
* The first version of this paper was written while I did an internship at the International Monetary Fund. Without implicating them, I am grateful to Stanley Black, Stanislava Brunner, Martin Daepp, Roland Daumont, Anne Epaulard, Norbert Funke, Hans Genberg, Samir Jahjah, Michael Lichtlen, André Santos, Doris Schiesser, Sunil Sharma, Abdelhak Senhadji, Antonio Spilimbergo, and Charles Wyplosz for helpful comments and discussions.

\# Author's e-mail address: peter1@ hei.unige.ch
} 


\section{Contents}

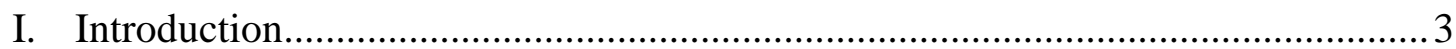

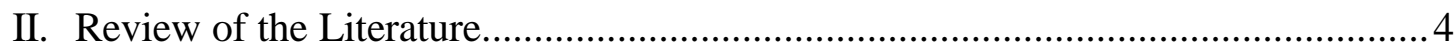

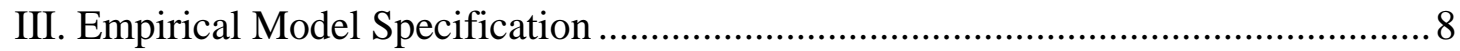

A. Definition of the Dependent Variable: Sovereign Default......................... 8

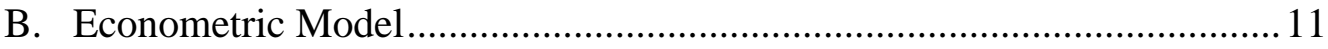

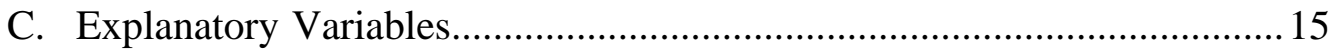

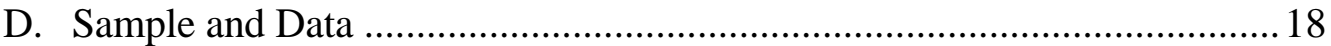

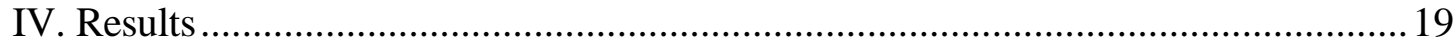

A. Significance of Explanatory Variables and In-Sample Prediction

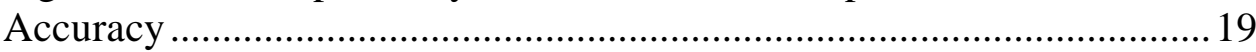

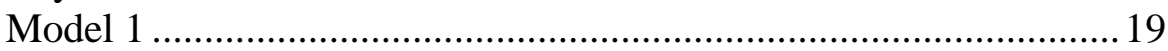

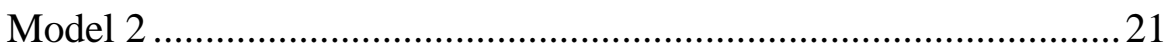

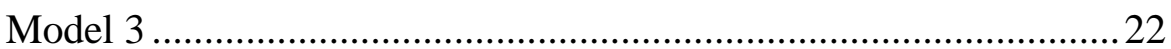

B. Out-of-Sample Prediction Accuracy ......................................................22

1997 Out-of-Sample Forecasts (Table 6)...................................... 24

1998 Out-of-Sample Forecasts (Table 7).......................................26

C. Comparison of Estimated Default Probabilities vs. Rating Agencies'

Default Rates.......................................................................................... 27

Sovereign Credit Ratings and Corresponding Default Rates............27

Before the Asian Crisis (Table 9) ..................................................... 29

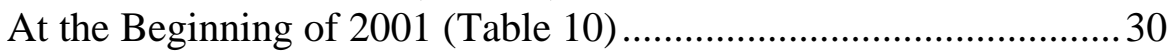

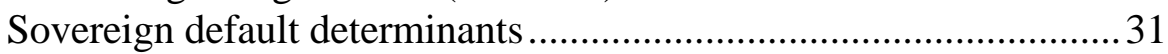

Adequacy of rating agencies' "sovereign" default rates.................... 32

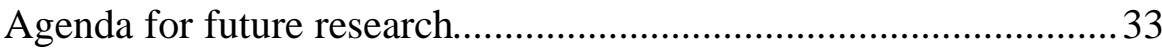

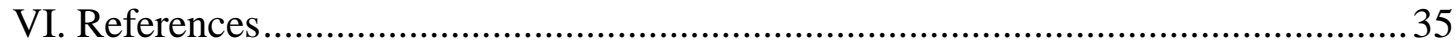

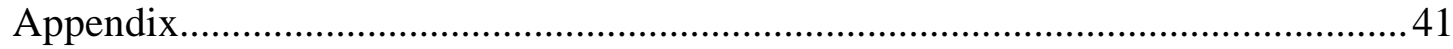

Table 1: Summary of Previous Studies Analyzing Sovereign Defaults .......... 41

Table 2: The Sample - Initial 150 Countries and 78 Emerging Markets

Eventually Analyzed, 1984-1997 .....................................................4 44

Figure 1: Number of Sovereign Defaults per Year, 1981-1998...................... 45

Table 3: Descriptive Statistics for the 11 Explanatory Variables, 1984-1997.45

Table 4: Estimation Results ...........................................................................4 46

Table 5: 3-Year-Ahead Default Probabilities (in \%) of Model 3 ...................4 47

Table 6: Out-of-Sample Performance of Model 3 in 1997 ..............................49

Table 7: Out-of-Sample Performance of Model 3 in 1998 .............................51

Table 8: Average 3-Year Cumulative Default Rates by Letter Rating .............53

Table 9: Model 3 Default Probabilities vs. Rating Agencies' Default Rates before Asian Crisis......................................................................... 54

Table 10: Model 3 Default Probabilities vs. Rating Agencies' Default Rates at

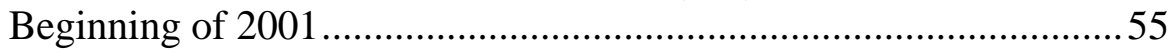




\section{INTRODUCTION}

"This book will be the definitive work on the debt crisis". [Paul Volcker on the back-cover of William R. Cline, 1995, International Debt Reexamined (Washington D.C.: Institute for International Economics).] - The idea for this paper emerged in August 1998 when Russia defaulted on large parts of its domestic (and, at the beginning of 1999, on its foreign) debt. The first paragraphs were written while Pakistan defaulted on foreign bank and bond debt (end 1998, beginning 1999). The paper progressed as Ecuador announced the first-ever default on Brady Bonds in August 1999 and as Indonesia's economic and political situation deteriorated to such an extent that it eventually had to default on foreign debt (April 2000). The conclusion is written while a depression-plagued Argentine government - amidst serious social unrest - declares the largest sovereign default in history (December 2001).

As sovereign debt crises continue to be a major concern for international financial markets and economic policy makers, this paper launches a new investigation into the determinants of sovereign default with the purpose of estimating default probabilities for emerging market governments (or "sovereigns"). These sovereign default probabilities are then compared with the default rates associated with the sovereign credit ratings of the two leading rating agencies, Standard \& Poor's and Moody's Investors Service.

Sovereign default probabilities can be useful for at least two reasons. First, they can be used to monitor the financial vulnerability of emerging market economies. The threat of possible (re-) payment problems of an emerging market government is very often at the source of financial market turbulence in such countries. Interestingly, the recent literature on the determinants ("early warnings indicators") of financial crises and contagion focuses almost exclusively on currency and banking crises and not directly on sovereign (re-)financing difficulties or default itself. ${ }^{1}$ At a recent "Economic Forum" organized by the IMF, one of the panelists, Kristin Forbes (MIT and U.S. Treasury), criticized this focus somewhat by saying: "What we should care about and what I'd like to see more work go into is models predicting things such as external financing difficulties and financial systems vulnerabilities, just as a few examples". ${ }^{2}$ This paper intends to address that gap in the literature.

Second, all major internationally operating banks use default probabilities to price bonds and loans, to feed their value-at-risk type credit risk management models, and to determine their complex customer and country exposure limits. Moreover, according to the current version of the New Basel Capital Accord ${ }^{3}$, banks will be allowed to use credit ratings and the corresponding default rates to determine the amount of regulatory capital they have to set aside against their credit risks. Thus, credit ratings and associated default rates play a crucial role in international capital

\footnotetext{
${ }^{1}$ See, for example, Goldstein, Reinhart, and Kaminsky (2000), Demirguc-Kunt and Detragiache (1999), Kaminsky and Reinhart (1999), Berg and Pattillo (1998), Corsetti, Pesenti, and Roubini (1998), Demirguc-Kunt and Detragiache (1998), Kaminsky (1998), Goldfajn and Valdes (1997), Honohan (1997), Kaminsky, Lizondo, and Reinhart (1997), Eichengreen, Rose, and Wyplosz (1996), Frankel and Rose (1996).

${ }^{2}$ See International Monetary Fund (2001)

${ }^{3}$ Basel Committee on Banking Supervision (2001).
} 
allocation. However, the problem is that there are no good sovereign default probabilities available. Consequently, international banks use corporate default rates collected by commercial rating agencies, such as Moody's Investors Service ("Moody's") or Standard and Poor's ("S\&P"), as proxies for sovereign default probabilities. Are they good proxies? This research uses the information contained in arrears and rescheduling data published by the World Bank, constructs a logit panel model to estimate probabilities of sovereign default and concludes that these proxies seem to underestimate sovereign default risk considerably.

The term "emerging markets" is used here similarly as most country credit risk managers use it. It encompasses generally all countries whose sovereign credit rating is A+ (on S\&P's scale; A1 on Moody's scale) or lower. Exceptions to this rule are usually Singapore (AAA with S\&P's, Aa1 with Moody's) and Taiwan (AA with S\&P's, Aa3 with Moody's), which are included in the list mainly for locational and political reasons. On the other hand, Greece (A with S\&P's, A2 with Moody's) has been dropped from the list upon joining the European Monetary Union. Apart from these exceptions, emerging markets are essentially all non-industrialized and transition economies.

The remainder of the paper is organized as follows. Section II provides a review of the more recent literature on the determinants of sovereign debt-servicing difficulties. Section III discusses the methodology used. First, the dependent variable ("sovereign default") is defined. Then, an empirical logit model is specified, the explanatory variables entering the model are discussed, and the sample as well as the data is described. Section IV presents the most important findings. It discusses the statistical and economic significance of the explanatory variables and evaluates the inand out-of-sample prediction accuracy of the model. Eventually, it compares the estimated and predicted default probabilities at two moments in time - before the Asian Crisis (end 1996) and at the beginning of 2001 - with the default rates associated with Moody's and Standard \& Poor's sovereign credit ratings. Section V concludes and draws some policy implications.

\section{REVIEW OF THE LITERATURE}

Since the early 1970s and especially since the beginning of the debt crisis in 1982, an extensive theoretical and empirical literature on the determinants of sovereign defaults has developed. Some authors - and especially internationally operating banks - forged the concept of "country (sovereign) risk analysis" to describe the process of identifying economic and political determinants and using them to form some qualified statement about the likelihood of a developing country experiencing external debt repayment problems. As the main goal of the paper is to estimate default probabilities of emerging market sovereigns, this review focuses on the empirical literature. However, readers interested in obtaining a quick overview of the broader issues related to sovereign debt are referred to Arora (1993). Theoretical treatments of sovereign debt and sovereign risk can be found in Obstfeld and Rogoff (1996), Eaton and Fernandez (1995), Eaton, Gersowitz, and Stiglitz (1986), and especially Cohen (1991). An excellent early systematic study of factors influencing a country's ability to service its foreign debt is Avramovic (1964). Ciarrapico (1992), finally, presents the theory of country risk from a more applied perspective. 
Useful surveys of the empirical literature on sovereign debt repayment difficulties are Cline, W. R. (1995), Avery and Fisher (1992), Saini, Krishan G and Bates (1984), and McDonald (1982) and those contained in Aylward and Thorne (1998), in Babbel (1996), in Ciarrapico (1992), and in Solberg (1988). With the exception of Aylward and Thorne (1998), however, these surveys only cover empirical investigations written up to the mid-1980s. Thus, the strategy in this section is to discuss, (1), the important empirical studies written in the field since the mid1980s and, (2), other empirical studies written since then but not surveyed in Aylward and Thorne (1998). ${ }^{4}$ Tables 1a to 1c give a synopsis of those studies. The first row identifies the papers. They are ordered according to, first, how they define the dependent variable and, second, their publication date. The next four rows show that they can be classified into four different groups with respect to how they define the dependent variable. The next 28 rows list the most frequently used explanatory variables and the columns indicate which of them haven been chosen by each of the authors. The mention "pos" means that the coefficient of the corresponding variable had a positive sign and was significant. "(pos)", on the other hand, means that the coefficient had a positive sign but was not significant, and similarly with "neg" and "(neg)". Below the explanatory variables, some goodness-of-fit measures, the estimation method and, eventually, the dimensions of each of the panel studies are reported.

What all of the surveyed studies (and most of the earlier papers mentioned in footnote 4) have in common is that they formulate the dependent variable ("debt service difficulty", "debt crisis" or "default") as a binary outcome, which takes on a value of 1 if the event (e.g. default) takes place and 0 otherwise. As a consequence, the functional relationship between the dependent variable and its determinants is modelled as a logit or probit model and panel discrete choice methods are used to estimate the coefficients of these models.

The remark by Aylward and Thorne (1998) with respect to the selection of determinants in the studies surveyed in their paper is also valid for a majority of the papers summarized in table 1: "The results of [the] work [by Avramovic (1964)] - the identification of short-term liquidity factors (the so-called traditional debt or financial ratios: debt/GDP, debt service/exports, reserves/imports) and longer-term indicators of economic health and growth (GDP growth rate, investment, exports, inflation) seem to have guided the selection of variables in many of the subsequent empirical analyses of external debt repayment behavior."5

Some studies - representing the so-called "ability-to-pay" approach - try to derive the binary dependent variable as well as the relevant determinants from theoretical models. Cline, W. (1984) and subsequently McFadden, Eckaus, Feder, Hajivassiliou, and O'Connell (1985), Hajivassiliou, V. A. (1987), Hajivassiliou, V. (1989), and Hajivassiliou, V. (1994) model the occurrence of a debt servicing difficulty as a situation of disequilibrium in international credit markets where the

\footnotetext{
${ }^{4}$ The more important of these earlier studies include Berg and Sachs (1988), Edwards (1984), Feder, Just, and Ross (1981), Eaton and Gersovitz (1981), Saini, Krishan G. and Bates (1978), Feder and Just (1977), Sargen (1977), and Frank and Cline (1971).

${ }^{5}$ Aylward and Thorne (1998), p. 12.
} 
demand for new loans to service existing debt exceeds the supply at the upper ceiling interest rate at which bankers are willing to lend. ${ }^{6}$ The determinants of debt default are then equal to the determinants of the demand for and the supply of new loans: Any factor that shifts the demand curve for new loans to the right and/or the supply curve of foreign credit to the left will tend to increase the probability of the emergence of a non-market clearing gap between demand and supply at the interest rate ceiling. Thus, as long as demand and supply curves cross below or at the interest rate ceiling, the country is able to borrow new funds to service its debt and, hence, does not default. However, if some factors shift the demand and/or supply curves such that the intersection lies above the interest rate ceiling, the country is unable to fully refinance itself and has no other option than to default. The binary choice (logit or probit) model is then interpreted as a reduced form model of this market for foreign credit.

Lee (1991), on the other hand, applies a "willingness-to-pay" approach, pioneered by Eaton and Gersovitz (1981) and Eaton et al. (1986). He models the event of a sovereign default as the outcome of a utility maximizing cost-benefit calculation by a sovereign borrower: a country defaults on its external debt if the expected value of the discounted utility of consumption with default exceeds the expected value of the discounted utility of consumption with debt service, and otherwise services its external debt. However, this willingness-to-pay approach does not necessarily have to be seen as an alternative to the foreign credit market - or ability-to-pay - approach above. It can be a complement in the sense that as long as the credit market clears at or below the interest rate ceiling, the willingness-to-pay is the binding constraint. Above the ceiling, the ability-to-pay determines the outcome.

Eventually, it is interesting to note that all these studies end up selecting determinants that are similar to those identified by Avramovic (1964) and subsequent empirical investigations on a less rigorous theoretical basis.

The most important difference among the studies summarized in table 1 is the definition of the dichotomous dependent variable, i.e. the definition of what constitutes a "debt servicing difficulty". Four different definitions have been identified among the 15 studies of table 1, depending on whether a country experiences one or more of three well defined expressions of a debt servicing problem: (1) a debt rescheduling negotiation or agreement, (2) arrears on interest payments or on principal repayments, and (3) an "upper-tranche" IMF agreement. ${ }^{7}$ In all studies but one (Aylward and Thorne (1998)), the rescheduling element is present in the definition. Cline, W. (1984), Citron and Nickelsburg (1987), Lee (1991), Balkan (1992), Odedokun (1995), Marashaden (1997), and Rivoli and Brewer (1997) all define a debt servicing difficulty observation as a year in which a country reschedules its external debt. Hajivassiliou, V. A. (1987) and Li (1992) add the uppertranche IMF agreement element to the definition. They assign the value of 1 to the dependent variable if a country reschedules its debt in a given year or concludes an upper-tranche IMF agreement. If neither of these two signs of external debt repayment problems is present, the corresponding country-year is assigned the value 0 . Callier (1985) and Detragiache and Spilimbergo (2000), instead, add the arrears element to the definition. But while Callier (1985) considers the presence of arrears on imports or on interest as an expression of a debt-servicing problem, Detragiache and Spilimbergo

\footnotetext{
${ }^{6}$ See Stiglitz and Weiss (1981) for a theory of credit rationing.

${ }^{7}$ For an exact definition of the latter, see Treasurer's Department (1998).
} 
(2000) require the stock of arrears to be larger than a certain threshold before they qualify a debt servicing problem as a "debt crisis". Their dependent variable takes on the value of 1 if either or both of the following conditions occur: (1) the stock of arrears of principal or interest on external obligations towards private creditors exceeds $5 \%$ of total long-term debt service due; (2) there is a rescheduling or debt restructuring agreement with private creditors as listed in the World Bank publications Global Development Finance.

The default definition of McFadden et al. (1985), Hajivassiliou, V. (1989), and Hajivassiliou, V. (1994), eventually, comprises all three elements: a country experiences a debt repayment problem in a given year (i.e. dependent variable $=1$ ) if (1) it reschedules its debt with private or official creditors or, (2) it enters an IMF upper-tranche agreement or, (3) its stock of accumulated arrears is "significant", which is defined as interest arrears exceeding $0.1 \%$ of total external debt or principal arrears exceeding $1 \%$ of total external debt. Aylward and Thorne (1998), eventually, analyse separately countries' repayment performance towards the IMF and other creditors. To our knowledge, theirs is the only study in the literature to define the occurrence of an external repayment problem as the simple presence of arrears on interest or principal. For the purposes of this paper, all of these definitions have certain drawbacks. Section III A explains why and specifies a definition that seems more appropriate.

As far as the explanatory variables are concerned, table 1 makes clear that there are not even two studies with exactly the same determinants of debt servicing difficulties. Despite these differences, some summary conclusions may be drawn. First, the three determinants that are most often tested and seem most consistently to be significant are the so-called financial ratios reserves/imports, total external debt/GDP, and - to a lesser extent - total debt service due/exports. Second, as far as the indicators of the macroeconomic situation and policy stance are concerned, the results are mixed: GDP growth or GDP per capita growth, current account balance/GDP, inflation, and measures of exchange rate overvaluation have been found significantly associated with debt servicing capacity in some studies, but insignificant in others. Third, where the lagged dependent variable has been included among the determinants, it has been found highly significant. Fourth, only few studies (Citron and Nickelsburg (1987), Balkan (1992), Li (1992), Rivoli and Brewer (1997)) tried to test the significance of political variables even though such factors are generally acknowledged to be important.

For the investigations in this paper, we use the list of explanatory variables in table 1 as a starting point for the selection of determinants. In particular, we construct and test an indicator of exchange rate misalignment and use a set of political risk indicators ${ }^{8}$ as potential determinants of sovereign defaults that have not yet been used in the literature. Section III C provides the details about the explanatory variables chosen in this paper.

Concerning the goodness-of-fit of the empirical models surveyed in table 1, Aylward and Thorne (1998) achieve the best performance with a model that classifies

\footnotetext{
8 "Political Risk Points by Component", published by The PRS Group in their monthly publication International Country Risk Guide.
} 
$94.78 \%$ of debt defaults and non-defaults correctly (in sample). Moreover, the percentage of type I errors (i.e. actual defaults classified by the model as non-defaults) and the percentage of type II errors (i.e. actual non-defaults classified by the model as defaults) are very low: $8 \%$ and 3\% respectively. Very similar results are achieved by Balkan (1992), which includes political variables, with $94.6 \%$ of correct classifications and type I and type II errors of 7.3\% and 5.2\%, respectively.

As to the period analyzed, eventually, most of the studies cover some period between the early 1970s and the early 1990s, the only exception being Detragiache and Spilimbergo (2000), which cover the period 1971-1998. However, in their paper, Detragiache and Spilimbergo (2000) study financial crises in a broader sense and the analysis of the determinants of debt defaults is a mere by-product. Thus, given the lack of a systematic study of the determinants of debt repayment problems covering the period since the onset of the debt crisis in 1982, this paper intends to make a contribution towards filling that gap.

A closely related, but nevertheless distinct, empirical literature analyzes the determinants of sovereign creditworthiness ratings, such as Moody's "country ceilings", Standard \& Poor's "sovereign credit ratings" or the country risk ratings produced by the Institutional Investor, Euromoney, the Economist Intelligence Unit (EIU), and the PRS (Political Risk Services) Group. An early example of this literature is Feder and Uy (1985). More recent studies in this field include Oral, Kettani, Cosset, and Daouas (1992), Lee (1993), Sommerville and Taffler (1995), Cantor and Packer (1996), Haque, Nadeem Ul, Kumar, Mark, and Mathieson (1996), and Haque, Nadeem U., Mark, and Mathieson (1998), and Jüttner and McCarthy (2000).While the literature on sovereign debt repayment problems tries to analyze the likelihood of such a problem and its determinants directly, this literature does it indirectly by analyzing the determinants of country creditworthiness ratings, which are indicators of how international investors perceive the likelihood of a repayment problem. Ideally, i.e. if the various rating agencies manage to integrate the relevant information into their sovereign ratings, these two strings of the literature should find the same determinants. A companion paper, Peter (2002), will elaborate on the observation that this is not really the case.

\section{EMPIRICAL MODEL SPECIFICATION}

\section{A. Definition of the Dependent Variable: Sovereign Default}

This paper attempts to derive external debt default probabilities for emerging market sovereigns. How do international capital markets define the term "default"? The two leading rating agencies and market specialists in debt default problems, Moody's Investors Service and Standard \& Poor's, define "default" as (1) "any missed or delayed payment of interest and/or principal or (2) any exchange where the debtor offers the creditor a new contract that amounts to a diminished financial obligation (e.g., preferred or common stock, debt with a lower coupon or par amount, or a less liquid deposit either because of a change in maturity or currency of denomination, or required credit maintenance facilities) or (3) where the exchange has 
the apparent purpose of helping the borrower avoid default." missed or delayed payments of interest and/or principal...", clearly indicates that the accumulation of interest and/or principal repayment arrears constitutes a default. The second part, "... a new contract that amounts to a diminished financial obligation..." can be considered as a definition of a rescheduling agreement, which constitutes a default as well. In this sense, it seems appropriate to focus on debt payment arrears and rescheduling arrangements as expressions of default.

Data on the number and nature of individual rescheduling arrangements between developing country governments and their creditors are not readily available. They have to be tediously compiled from various sources. For large panel studies, this implies very large costs. ${ }^{10}$ Additionally, as Cline, W. (1984), p. 207, notes, debt reschedulings are usually preceded by the accumulation of arrears on debt payments. This implies that any definition of default should attribute priority to the accumulation of arrears. Reschedulings are only important to the extent that they take place independently of arrears. In the absence of easily accessible information on individual rescheduling arrangements, we use the data series "total amounts of debt rescheduled (US\$)" that can be found on the World Bank CD-ROM Global Development Finance $(G D F)^{11}$. The question of whether any amount of "debt rescheduled" constitutes a default is treated below.

Data on arrears (on long-term debt) of interest and principal, on the other hand, is now available on the GDF CD-ROM. One of the possible explanations why only few of the surveyed studies used arrears data to define their dependent variable is that the World Bank publishes them only since 1989-90. McFadden et al. (1985), Hajivassiliou, V. (1989) and Hajivassiliou, V. (1994) could make use of arrears data because they had privileged access to confidential World Bank files, as they note in their papers. Looking at principal and interest arrears data for the 138 countries covered on the GDF 1999 CD-ROM, one might be surprised about the pervasiveness and amounts of interest and principal arrears towards public and private creditors. This raises the question of whether any amount of accumulated arrears should be considered as a default (see Aylward and Thorne (1998)) - in which case there would be many more country-years in default than not! - or whether some minimum threshold amount should be crossed before arrears would be classified as debt default (e.g. $0.1 \%$ of total external debt for interest arrears and $1 \%$ of total external debt for principal arrears in McFadden et al. (1985) or 5\% of total long-term debt service due for the sum of interest and principal arrears in Detragiache and Spilimbergo (2000)).

This paper argues that relatively small amounts of arrears do not threaten the functioning of international credit markets or might even occur out of inadvertence. Hence the imposition of a threshold seems justified. Imposing a threshold to the stock of accumulated arrears seems problematic, though. Suppose we set the default threshold for the stock of total (i.e. interest and principal) arrears at $1 \%$ of total external debt. Suppose further that country X incurs arrears worth $2 \%$ of total debt in

\footnotetext{
${ }^{9}$ See Moody's Investors Service (1999b), p. 1. For S\&P's (similar) definition, see Standard \& Poor's (1999b), p. 10.

${ }^{10}$ All of the surveyed studies that used rescheduling arrangements in their definition (except Detragiache and Spilimbergo (2000)) had to go this way.

${ }^{11}$ The code of this series is DT.TXR.DPPG.CD.
} 
year $t$ and then reduces this stock of arrears at such a rate that it drops below the $2 \%$ threshold in year $t+4$. According to this rule, country $X$ would be classified as defaulting on its external debt for three subsequent years while, in reality, it started to dismantle its stock of arrears from year $\mathrm{t}+1$ on. A country that reduces its arrears stock relative to total debt must either have the resources to service its debt or must have benefited from some kind of debt reduction scheme. Both cases would be judged as positive developments by capital markets and the classification of country $\mathrm{X}$ as being in default in year $t+1, t+2$ and $t+3$ would seem unjustified.

To avoid that problem, this paper defines the default threshold in terms of increases in the stock of arrears. An emerging market sovereign (i.e. a government) is considered to default on its external debt in a given year if either or both of conditions (1) and (2), plus condition (3), are fulfilled:

(1) the increase in the stock of total (i.e. interest and principal) arrears (on longterm debt) towards official and private creditors exceeds $2 \%$ of total external debt;

(2) the total amount of (long-term) debt rescheduled in a given year exceeds $2.5 \%$ of total external debt;

(3) if (2) is fulfilled but, at the same time, the stock of total arrears (in US\$ terms) decreases by more than the total amount of debt rescheduled (in US\$ terms), the observation does not count as default.

If these conditions are fulfilled for a given country-year, the dependent variable $d_{i t}$ (for "default") takes on the value of 1 for this observation and 0 otherwise, i.e.

$$
d_{i t}= \begin{cases}1 & \text { if country } i \text { defaults in year } t \\ 0 & \text { if country } i \text { does not default in year } t\end{cases}
$$

Condition (3) should allow us to avoid classifying as default an observation where a country had a significant amount of debt rescheduled (i.e. defaulted according to condition (2)) but, at the same time, managed to decrease it's stock of arrears by more than the amount rescheduled. The threshold of $2 \%$ in condition (1) and that of $2.5 \%$ in condition (2) correspond roughly to the sample means of the two correspondding data series (i.e. increase in total arrears and total amounts of debt rescheduled, both as a percentage of total external debt). As is the case for the thresholds imposed by the studies surveyed in table 1, these ones are also arbitrary. However, there are two points to be noted.

First, we also tried thresholds of $1.5 \%$ and $3 \%$ for both series but neither the number of defaults identified nor the estimation results changed significantly. Second, with these two thresholds for the increase in total arrears and the total amount of debt rescheduled, we interestingly obtain a number of sovereign defaults per year that is reasonably close to the number counted by Standard \& Poor's in their most recent sovereign default survey. ${ }^{12}$ For the 150 countries of table $2,{ }^{13}$ figure 1 compares the

\footnotetext{
${ }^{12}$ See Standard \& Poor's (2001c), p. 94. Standard \& Poor's is the only rating agency that publishes detailed sovereign default statistics so far. The only other source for historical data on sovereign defaults that we could identify is Beim and Calomiris (2001), pp. 32-36. The sovereign defaults listed in this textbook correspond closely to those identified by S\&P's.
} 
number of sovereign defaults obtained by the above definition with the number identified by Standard \& Poor's over the period 1981-1997. From 1985 on, the distribution of defaults per year as well as the total number of defaults identified by our own definition (total number 1985-97: 664) is fairly similar to the distribution and total number identified by S\&P's (total number 1985-97: 649). The major difference in the number of defaults occurs at the beginning of the period of analysis, between 1981 and 1984, with S\&P's identifying many more defaults (135) than we do (42). This seems largely due to the fact that at the outset of the debt crisis, the increase in the stock of arrears of defaulting countries was relatively small compared to the outstanding external debt, resulting in many instances where the threshold of $2 \%$ in terms of total external debt is not crossed. For reasons explained in section III D, potential bias problems are minimized as the years 1981 to 1983 are, anyway, excluded from our sample.

\section{B. Econometric Model}

Following the literature in the field, we combine the various default determinants of ability- and willingness-to-pay approaches (see table 1) and derive a (binary choice) reduced-form model that expresses the probability of default as a function of these (economic and political) determinants. The binary choice model is derived in the following steps.

Consider a random sample of $N$ emerging market countries (or sovereigns), $i=$ $1, \ldots, N$. Each sovereign $i$ is observed over $T$ periods, $t=1, \ldots, T$. Assume that there exists an unobservable (continuous random) variable $y_{i t}^{*}$ that indicates whether sovereign $i$ defaults in year $t$. Assume that this unobservable indicator $y_{i t}^{*}$ is a linear function of a vector of $k$ (exogenous) determinants, $\mathbf{x}_{i t}$, of a constant $a$ and of a random error term $\varepsilon_{i t}$

$$
y_{i t}^{*}=a+\mathbf{b}^{\prime} \mathbf{x}_{i t}+\varepsilon_{i t},
$$

where b is a $(k \times 1)$ vector of parameters.

As to the random error term, we make two assumptions. First, we assume that all $\varepsilon_{i t}$ are independent and identically distributed across countries and over time and have zero mean and unit variance, i.e.

$$
\varepsilon_{i t} \sim \text { i.i.d. }[0,1] \text { for all } i \text { and } t .
$$

Second, we assume that these errors $\varepsilon_{i t}$ have a logistic distribution,

$$
\varepsilon_{i t} \sim \Lambda[0,1] .
$$

The logistic cumulative distribution function (CDF) has the following form

$$
\Lambda(X)=\frac{\exp \left(\frac{\pi}{\sqrt{3}} \frac{X-\mu}{\sigma}\right)}{1+\exp \left(\frac{\pi}{\sqrt{3}} \frac{X-\mu}{\sigma}\right)},
$$

\footnotetext{
${ }^{13}$ See section III D for details about the sample and the data.
} 
which implies that its probability density function (PDF) is

$$
\lambda(X)=\frac{\exp \left(\frac{\pi}{\sqrt{3}} \frac{X-\mu}{\sigma}\right)}{\frac{\pi}{\sqrt{3}} \cdot \sigma \cdot\left(1+\exp \left(\frac{\pi}{\sqrt{3}} \frac{X-\mu}{\sigma}\right)\right)^{2}}
$$

where $\mu=$ mean and $\sigma^{2}=$ variance. The CDF of our standardized error term $\varepsilon_{i t}$ is thus

$$
\Lambda\left(\varepsilon_{i t}\right)=\frac{\exp \left(\frac{\pi}{\sqrt{3}} \varepsilon_{i t}\right)}{1+\exp \left(\frac{\pi}{\sqrt{3}} \varepsilon_{i t}\right)} .
$$

The assumption of the errors being i.i.d. (equation 3) yields the simplest possible "panel" model. ${ }^{14}$ The assumption of a unit variance is an innocent normalization. ${ }^{15}$ The assumption of logistically distributed error terms (equation 4) yields the logit model. If the errors were assumed to be standard normal instead, we would obtain a probit model. ${ }^{16}$

Next, we assume that a country defaults if the unobservable default indicator is greater than one, i.e. if $y_{i t}^{*}>0$, and that it does not if $y_{i t}^{*} \leq 0$, i.e.

$$
d_{i t}=\left\{\begin{array}{ll}
1 & y_{i t}^{*}>0 \\
0 & y_{i t}^{*} \leq 0
\end{array} .\right.
$$

Equation (8) helps us to introduce our binary (and observed!) dependent variable of equation (1) into the model. Thus, the probability of observing a sovereign default in year $t$, i.e. the probability that $d_{i t}=1$, is

$$
\begin{gathered}
\operatorname{Prob}\left(d_{i t}=1\right)=\operatorname{Prob}\left(y_{i t}^{*}>0\right)=\operatorname{Prob}\left(a+\mathbf{b}^{\prime} \mathbf{x}_{i t}+\varepsilon_{i t}>0\right) \\
=\operatorname{Prob}\left(\varepsilon_{i t}>-a-\mathbf{b}^{\prime} \mathbf{x}_{i t}\right) .
\end{gathered}
$$

Using equation (7) and the property of the logistic distribution function, ? , to be symmetric, the probability of a sovereign default is

$$
\operatorname{Prob}\left(d_{i t}=1\right)=\operatorname{Prob}\left(\varepsilon_{i t}<a+\mathbf{b}^{\prime} \mathbf{x}_{i t}\right)=\frac{\exp \left(\alpha+\boldsymbol{\beta}^{\prime} \mathbf{x}_{i t}\right)}{1+\exp \left(\alpha+\boldsymbol{\beta}^{\prime} \mathbf{x}_{i t}\right)}
$$

while the probability of no sovereign default is

$$
\operatorname{Prob}\left(d_{i t}=0\right)=1-\operatorname{Prob}\left(d_{i t}=1\right)=\frac{1}{1+\exp \left(\alpha+\boldsymbol{\beta}^{\prime} \mathbf{x}_{i t}\right)},
$$

with $\alpha=\frac{\pi}{\sqrt{3}} a$ and $\boldsymbol{\beta}=\frac{\pi}{\sqrt{3}} \mathbf{b}$.

\footnotetext{
14 „Panel“, in quotation marks, because this error assumption effectively ignores the panel structure of the data. A more realistic modelling of the error term is considered in further research.

${ }^{15}$ See Greene (2000), p.819, for more details about this normalization.

${ }^{16}$ The two distributions are similar. The standardized logistic distribution has slightly heavier tails than the standard normal distribution. In effect, it closely resembles a $t$-distribution with seven degrees of freedom. We used both logit and probit models in the analysis. But since the results were similar, we preferred to work with the much simpler logistic distribution.
} 
Assuming $\varepsilon_{i t}$ to be i.i.d. across countries and over time (equation 3) and using equations (9) and (10), the (unconditional) joint probability, or likelihood, function for the $N \cdot T$ observations of the panel can be written as

$$
L=\frac{\prod_{i=1}^{N} \prod_{t=1}^{T} \exp \left[\left(\alpha+\boldsymbol{\beta}^{\prime} \mathbf{x}_{i t}\right) d_{i t}\right]}{\prod_{i=1}^{N} \prod_{t=1}^{T}\left[1+\exp \left(\alpha+\boldsymbol{\beta}^{\prime} \mathbf{x}_{i t}\right)\right]} .
$$

The constant $\alpha$ and the parameter vector $\boldsymbol{\beta}$ can be estimated by maximizing the likelihood function with respect to these parameters and solve for them iteratively. ${ }^{17}$

While we are interested in these parameters in order to analyze which determinants are significant and in order to calculate sovereign default probabilities, we have to be aware of the fact that they are not the marginal effects we are used to obtain in linear models. Binary choice models are non-linear in the parameters and in the explanatory variables. Fortunately, however, the simplicity of the logit model allows us to obtain closed-form solutions of these marginal effects. Let $x_{i t, k}$ be the $k$ th element of the determinant vector $\mathbf{x}_{i t}$, and let $\beta_{k}$ be the $k$ th element of $\boldsymbol{B}$. Then the partial derivative of the sovereign default probability, $\operatorname{Prob}\left(d_{i t}=1\right)$, with respect to $x_{i t, k}$ is

$$
\frac{\partial}{\partial \mathbf{x}_{i t, k}} \operatorname{Prob}\left(d_{i t}=1\right)=\frac{\exp \left(\alpha+\boldsymbol{\beta}^{\prime} \mathbf{x}_{i t}\right)}{\left[1+\exp \left(\alpha+\boldsymbol{\beta}^{\prime} \mathbf{x}_{i t}\right)\right]^{2}} \beta_{k} .
$$

A comparison of equation (12) with equation (6) tells us that the marginal impact of the $k$ th determinant on the default probability is a function of the logistic PDF of the linear combination $\left(\alpha+\boldsymbol{\beta}^{\prime} x_{i t}\right)$, i.e. $\frac{\exp \left(\alpha+\boldsymbol{\beta}^{\prime} \mathbf{x}_{i t}\right)}{\left[1+\exp \left(\alpha+\boldsymbol{\beta}^{\prime} \mathbf{x}_{i t}\right)\right]^{2}}$, and of the coefficient of this determinant, $\beta_{k}$. In other words, the marginal effects (or "slopes") of each determinant do not only depend on the size of this determinant at the point of evaluation but also on the sizes of all other determinants at that point. In interpreting the importance of the determinants, we will thus have to evaluate these slopes at certain values of the explanatory variables. As is commonly done with logit models, we will evaluate the marginal effects at the sample means of the determinants.

Eventually, let us modify the model slightly in order to make it more "forward-looking" and to limit potential endogeneity problems. We are interested in how the vector of determinants $\mathbf{x}$ at time $t$ determines country $i$ 's probability of

\footnotetext{
${ }^{17}$ For more details about the logit and other binary choice models and their estimation, see Maddala (1983). For an introduction into the problems of estimating discrete dependent variable models in a panel context, see chapter 19 in Greene (2000), and Arellano and Honore (2001). For more advanced treatments of how to estimate dynamic discrete choice models and how to take into account the problem of unobserved heterogeneity, see Heckman (1981) and Honore and Kyriazidou (2000).
} 
default in year $\mathrm{t}$ and/or the near to medium term future. In other words, we want to determine to what extent the knowledge of a country's economic and political situation today helps us to determine the likelihood of default by this country in the near future ("early warning tool"). Thus, the binary dependent variable $d_{i t}$ defined in equation (1) is slightly modified: $d$ for country $i$ will take on the value 1 if country $i$ defaults in year $t$ and/or $t+1$ and/or ... and/or $t+p$, and 0 otherwise, i.e.

$$
d_{i, t \ldots t+p}= \begin{cases}1 & \text { if country } i \text { defaults over the period } t \text { until } t+p \\ 0 & \text { if country } i \text { does not default over the period } t \text { until } t+p .\end{cases}
$$

This formulation of the dependent variable could be interpreted as some kind of smoothing and takes account of the fact that it is very difficult to predict the precise timing of a sovereign default. Rather, a certain number of economic and political "fundamentals" might indicate repayment problems over some years ahead. Therefore, it seems interesting to investigate how many years ahead these determinants seem to have some bearing. In order to limit complexity and the loss of observations, we have chosen $p=2$. Consequently, the six resulting definitions of the dependent variable we will consider are:

$$
\begin{aligned}
& d_{i ; t}= \begin{cases}1 & \text { if country } i \text { defaults in year } t \\
0 & \text { if country } i \text { does not default in year } t\end{cases} \\
& d_{i ; t+1}= \begin{cases}1 & \text { if country } i \text { defaults in year } t+1 \\
0 & \text { if country } i \text { does not default in year } t+1 .\end{cases} \\
& d_{i ; t+2}= \begin{cases}1 & \text { if country } i \text { defaults in year } t+2 \\
0 & \text { if country } i \text { does not default in year } t+2\end{cases} \\
& d_{i ; t, t+1}= \begin{cases}1 & \text { if country } i \text { defaults at least once over the period } t \text { 'til } t+1 \\
0 & \text { if country } i \text { does not default over the period } t \text { 'til } t+1\end{cases} \\
& d_{i ; t+1, t+2}= \begin{cases}1 & \text { if country } i \text { defaults at least once over the period } t+1 \text { 'til } t+2 \\
0 & \text { if country } i \text { does not default over the period } t \text { 'til } t+2 .\end{cases} \\
& d_{i ; t, t+1, t+2}= \begin{cases}1 & \text { if country } i \text { defaults at least once over the period } t \text { 'til } t+2 \\
0 & \text { if country } i \text { does not default over the period } t \text { until } t+2 .\end{cases}
\end{aligned}
$$

As a consequence, the unobservable and random sovereign default indicator $y_{i t}^{*}$ will be re-interpreted as indicating whether sovereign $i$ defaults over the period $t$ until $t+2$ and re-written $y_{i ;, \ldots . t+2}^{*}$. All other equations will be adjusted accordingly. In particular, the core equation (9) will now read

$$
\operatorname{Prob}\left(d_{i ; t . t+2}=1\right)=\frac{\exp \left(\alpha+\boldsymbol{\beta}^{\prime} \mathbf{x}_{i t}\right)}{1+\exp \left(\alpha+\boldsymbol{\beta}^{\prime} \mathbf{x}_{i t}\right)},
$$

i.e. for each country $i$, the vector of (country-specific and global) explanatory variables in year $t, \mathbf{x}_{i t}$, determines the probability that country $i$ will default at 
various horizons between $t$ and $t+2$. The next section discusses the determinant vector $\mathbf{x}_{i t}$.

\section{Explanatory Variables}

Among the many potentially relevant model specifications implied by the sovereign default determinants listed in table 1, we have chosen the one that fulfilled the following conditions: (1) the chosen determinants are individually and jointly significant in the equation; (2) all determinants show the expected sign; and (3) the fit to the data is maximized. The best results were obtained by a specification that includes the 11 variables listed below. For each of them, a brief description specifies how it is expected to be correlated with the occurrence of sovereign default:

1. CAGDPN = current account balance as a $\%$ of GDP

$>$ Expected parameter: negative. An improving current account position reduces the dependence on foreign savings, slows down the increase in the (net) foreign debt stock (if CAGDPN is less negative from one period to the other) or even reduces the (net) foreign debt stock (if CAGDPN is positive from one period to the next) and, thus, reduces the likelihood of a default on foreign debt. Conversely, for countries with large current account deficits, any shock disrupting a country's access to international financial markets will compound the problem of servicing maturing debt with that of finding a substitute for the real resource transfer the country relied upon. Hence, the larger the current account deficit relative to GDP, the higher the probability of experiencing debtservicing difficulties.

2. LDEBST2 $=$ debt stock indicator, comprising the total debt/GNP ratio and the total debt/exports of goods and services ratio at the end of the previous year ${ }^{18}$

$>$ Expected parameter: positive, since an increasing debt stock, compared to the resource base (whether GDP, GNP or export earnings), increases the likelihood that the debt is unsustainable and, hence, of default.

3. LARREDT $=$ total accumulated arrears (on interest payments and principal repayments to official and private creditors) as a \% of total external debt at the end of the previous year.

Expected parameter: positive, since the higher the stock of already accumulated arrears, the higher the risk of further defaults.

4. $\mathrm{M} 2 \mathrm{IR}=$ money and quasi money $(\mathrm{M} 2)$ to gross international reserves ratio ${ }^{19}$

\footnotetext{
${ }^{18}$ LDEBST2 $_{2}=\left(\mathrm{DGNP}_{\mathrm{t}-1}-\mu_{\mathrm{DGNP}}\right) / \mathrm{s}_{\text {DGNP }}+\left(\mathrm{DEXP}_{\mathrm{t}-1}-\mu_{\mathrm{DEXP}}\right) / \mathrm{s}_{\text {DEXP }}$, where DGNP and DEXP are the total debt-GNP ratio and the total debt-exports ratio, respectively, and where $\mu$ and $s$ are the respective sample means and standard deviations.

${ }^{19}$ Other indicators of reserve adequacy have been tested (international reserves in months of imports, international reserves to short-term external debt), but were found to be insignificant.
} 
$>$ Expected parameter: positive. In a fixed or managed floating exchange rate regime (i.e. the situation of most developing countries), the ratio of M2 (in US\$) to foreign reserves is a measure of the extent of un-backed implicit government (i.e. central bank) liabilities. ${ }^{20}$ The higher the stock of money (M2) compared to international reserves, the higher the probability that a sudden loss in confidence in a country's currency leads to a liquidity/currency/balance-of-payments crisis and/or an external debt default. ${ }^{21}$

5. $\mathrm{CRPRIV}=$ credit to private sector $(\%$ of GDP $)$

$>$ Expected parameter: positive, since the higher the indebtedness of the private sector compared to the size of the economy, the higher the likelihood of mass private defaults (e.g. by large banks or companies/conglomerates) in case of a cyclical downturn, hence the higher the probability of a banking crisis, which may force the government to bail out large banks and, thereby, to slither itself into payment difficulties.

6. CPIINF2 = consumer price inflation (\% change, average)

$>$ Expected parameter: positive. A high rate of inflation points to structural problems in the government's finances. When a government appears unable or unwilling to pay for current expenditure through taxes or debt issuance, it must resort to printing money. This will lead to inflation, which in turn will reduce the (non-indexed) outstanding domestic debt. Inflationary finance can be interpreted as default on domestic debt. Thus, as an indicator of fiscal (and monetary) policy (mis-) management, higher inflation rates might indicate a higher probability of default on external debt as well, in spite of the government's inability to inflate away foreign currency denominated debt. ${ }^{22}$

7. $($ DRER2HP)^ $2=$ squared percentage deviation of real exchange rate (vis-à-vis the US\$) from long-run trend ${ }^{23}$

Expected parameter: positive. On one hand, if a currency is sharply overvalued, there is a high risk of a currency crisis that may lead to a debt crisis. On the other hand, a strong under-valuation of a currency (e.g. caused by a sharp devaluation as a result of a currency crisis) implies a large real external debt burden in terms of

\footnotetext{
${ }^{20}$ See Calvo and Mendoza (1996), pp. 243 and 249.

${ }^{21}$ According to Calvo (1996), the M2-interntional reserves ratio is a good predictor of a country's vulnerability to balance of payments crises.

${ }^{22}$ As the benefit of inflation rates below $2 \%$ is doubtful, we actually put a lower bound of $2 \%$ to all inflation rates. For instance, instead of Ethiopia's actual inflation rate in 1996 of $-5.1 \%$, the value entered in the model was $2 \%$.

${ }^{23}$ Our measure of the long-run trend real exchange rate is the Hodrick-Prescott filtered real exchange rate index, calculated as the relative consumer prices expressed in country i's currency. The idea of this measure of misalignment is similar to the ones used in Frankel and Rose (1996) or Kaminsky and Reinhart (1999), except for the calculation of the trend.
} 
domestic currency. Thus, the larger the deviations of the real exchange rate from long run trend, the higher the risk of default. The fact that drer2hp is squared implies that the risk of default increases more than proportionately as the deviation increases. We first tried with the absolute value of drer $2 \mathrm{hp}$ but in this form, the variable was not significant. The squared value of drer $2 \mathrm{hp}$, however, turned out to be significant. The same was true for $(|\operatorname{drer} 2 \mathrm{hp}|)^{\wedge} 3$ and $(\mathrm{drer} 2 \mathrm{hp})^{\wedge} 4$, where the level of significance was even slightly higher.

8. VGNPCAPG2 = variability of GNP-per-capita growth, calculated as the standard deviation of GNP-per-capita growth over the preceding 7 years.

$>$ Expected parameter: positive, since the more a country's output fluctuates, the higher the probability that in a given year the country might not have (or might not be willing to make available for debt service) the necessary resources to pay interest and/or principal, i.e. the higher the probability that it defaults.

9. POLRISK6 $=$ political risk index, calculated as the sum of six "political risk components" published monthly by the PRS-Group, i.e. POLRISK6 = CORRUPT+SOCECO+INVPROF+MILIT+ETHNIC+DEMO, whereby

- CORRUPT $=$ index of corruption within the political system (ranging between $0=$ heavy corruption, and $6=$ virtually no corruption)

- $\mathrm{SOCECO}=$ index of a country's socioeconomic conditions (0-12)

- INVPROF = index of a country's investment profile (0-12)

- $\quad$ MILIT $=$ index of involvement of the military in politics (0-6)

- $\quad$ ETHNIC $=$ index of the degree of ethnic tensions in a country (0-6)

- $\mathrm{DEMO}=$ index of a government's democratic accountability (0-6)

POLRISK6 thus has a potential range from 0 (= very high political risk) to 48 (very low political risk).

Expected parameter: negative, since the more "difficult" the political situation as indicated by the six components of our political risk indicator (i.e. the lower the indicator) in a country, the higher the probability of default.

10. LIB6MRE1 = real interest rate on international lending, calculated as 6-months LIBOR on U.S. dollar deposits minus expected U.S. consumer price inflation. ${ }^{24}$ This is actually not a country-specific but an international factor that affects all countries in the same way.

$>$ Expected parameter: positive, since the higher the cost of borrowing and/or of interest payments (for variable debt), the higher the probability of default

11. L3DOREDT3ME = lagged dependent variable $($ lag length $=3$ ), i.e. this indicator has a value of 1 if the country had defaulted over the past three years and 0

\footnotetext{
${ }^{24}$ In the estimation, we used actual U.S. CPI inflation over the following year.
} 
otherwise. As such, this variable can also be interpreted as an indicator of repayment performance over the recent past.

$>$ Expected parameter: positive, since default data show a high degree of positive auto-correlation, i.e. the probability that a country will default in the future if it has defaulted in the past, or that it won't default in the future if it hasn't defaulted in the past, is very high.

\section{Sample and Data}

As noted in section II, this paper intends to study sovereign defaults since the onset of the debt crisis in 1982. We thus start our analysis by taking all 138 countries covered in the 1999 issue of the World Bank's Global Development Finance on CD$R O M$, the most comprehensive database on external indebtedness of developing countries. These are the countries that are aligned left in table 2. To these countries, we add the 12 emerging markets Bahrain, Cyprus, Hong Kong, Israel, Libya, Namibia, Qatar, Saudi Arabia, Singapore, Slovenia, Taiwan, and United Arab Emirates (countries aligned right in table 2), which are not covered in GDF but are considered to be important emerging markets and, hence, are covered in EIU CountryData on CD-ROM. ${ }^{25}$ Data on external debt, arrears and amounts of debt rescheduled are from these two sources. Data on economic variables are from the IMF's International Financial Statistics on CD-ROM and from the World Bank's World Development Indicators 1999 on CD-ROM. Data on political risk indicators are from PRS Group's International Country Risk Guide (various issues). ${ }^{26}$

Given the two-year lag of GDF data and the availability of the political risk indicators only as of 1984, our analysis is constrained to the period 1984-1997 - at best. Due to missing data, the eventual sample we end up with is an unbalanced panel containing anything from one to 14 time-series observations for only 78 of the 150 emerging markets. In all estimations, the actual number of observations floated around 720 observations. The 78 emerging markets eventually analyzed are yellowshaded in table 2 . Table 3 gives the descriptive statistics for the 11 explanatory variables discussed in section $\mathrm{C}$.

Following Eichengreen et al. (1996), the empirical currency crisis literature usually excludes a few years of observations after a crisis has started ("windowing technique") in order to account for possible structural changes as a consequence of the crisis and in order to limit the problem of endogeneity of the regressors. In order to limit the loss of observations, we chose a different approach. Instead of excluding the three time-series observations (i.e. 3 years) following a default, we include a dummy variable that takes the value of 1 if the country defaulted over the preceding 3 years and 0 otherwise. In effect, given the way our dependent variable is defined ( 1 if the

\footnotetext{
${ }^{25}$ One of three databases contained in EIU DataServices, a monthly publication by the Economist Intelligence Unit (EIU), London. This data was kindly provided by Credit Suisse First Boston (Zurich).

${ }^{26}$ Political Risk Services (PRS) Group, East Syracuse, New York.
} 
country defaulted in year $\mathrm{t}, \mathrm{t}+1$, or $\mathrm{t}+2$ and 0 otherwise), this dummy is nothing else than a lagged dependent variable with lag length equal to 3.

\section{RESUltS}

\section{A. Significance of Explanatory Variables and In-Sample Prediction Accuracy}

From the broad range of potentially relevant sovereign default indicators and possible model specifications, we tried to find the specification where the determinants were individually and jointly significant, had the expected sign, and produced the best fit to the data. In particular, the best results were obtained with definition 6 (see equation 13.6) of our dependent variable (see section III B), i.e. where the probability of default over the 3 years between $t$ and $t+2$ is modeled as a function of the 11 economic and political determinants at time $t$

$$
D P=\operatorname{Prob}\left(d_{i ; t, t+1, t+2}=1\right)=\frac{\exp \left(\alpha+\boldsymbol{\beta}^{\prime} \mathbf{x}_{i t}\right)}{1+\exp \left(\alpha+\boldsymbol{\beta}^{\prime} \mathbf{x}_{i t}\right)} .
$$

For simplicity, the default probability $\operatorname{Prob}\left(d_{i ; t, t+1, t+2}=1\right)$ will henceforth be called $D P$. Table 4 summarizes the estimation results for three specifications, called Model 1, Model 2, and Model 3. These three models differ with respect to the explanatory variables included.

\section{Model 1}

For Model 1 (column 1 of table 4), the likelihood ratio (LR) statistic and the tstatistics indicate that all explanatory variables are jointly and also individually statistically significant. A comparison with the list in section III C confirms that all determinants have the expected sign. As to the three explanatory variables that are used for the first time in this study, the political risk indicator (POLRISK6) is statistically one of the most significant variables; credit to the private sector/GDP (CRPRIV) is significant at the 5\% level; and our measure of real exchange rate misalignment (DRER2HP) is also significant at the 5\% level. The variable that turns out to be most significant is the lagged dependent variable (L3DOREDT3ME), i.e. the dummy variable that equals 1 if the country defaulted over the previous 3 years and is 0 otherwise. This result confirms the findings of earlier studies: state dependence appears to be very important in the case of sovereign defaults, i.e. even after controlling for other economic and political determinants, emerging market countries that defaulted in the recent past are more likely to default in the future than nondefaulting countries. ${ }^{27}$ The second most significant determinant is the real 6-months LIBOR (LIB6MRE1). Interestingly, only one of the surveyed studies (Lee (1991)) has found this world factor - a measure of the cost of international credit - to be significant.

As explained in section III B, the parameters in column 1 are not the marginal effects as the logit model is non-linear. Column 2 reports those marginal effects for each explanatory variable. They are evaluated at the means of the explanatory

\footnotetext{
${ }^{27}$ See, for instance, McFadden et al. (1985), Hajivassiliou, V. (1989), Hajivassiliou, V. (1994).
} 
variables (see descriptive statistics in table 3), using equation (12). ${ }^{28} \mathrm{~A}$ look at these marginal impacts shows that the (re-)payment performance over the recent past (L3DOREDT3ME) is not only the most significant determinant of sovereign default in statistical terms but also in economic terms: the fact of having defaulted over the past 3 years increases the probability of defaulting again over the next 3 years by fully $68.5 \%$, compared to a situation without default over the past 3 years. The second most important ${ }^{29}$ determinant from an economic viewpoint is the real 6-months LIBOR rate (LIB6MRE1): an increase of 100bp in the real 6-months LIBOR increases the default probability of the average emerging market by over 9 percentage points. This value seems quite high and would underscore the important role that conditions on international capital markets play for emerging markets. It would also somewhat qualify the view that emerging market debt defaults have purely "home made" roots. Unfortunately, Lee (1991) - the only surveyed paper that found this measure of the cost of foreign credit to be significant - does not calculate the marginal effects, so we cannot compare the results.

Two other very important determinants of sovereign default appear to be the political risk indicator (POLRISK6) and the variability of real GNP-per-capita growth (VGNPCAPG2), measured as the standard deviation of real GNP-per-capita growth over the preceding 7 years. A one-unit increase in POLRISK6 (meaning a decrease in political risk) reduces the default probability by $2.5 \%$ while a one-unit increase in VGNPCAPG2 increases the probability of default by $2.7 \%$. The debt-stock indicator (LDEBST2) seems to be important too, its marginal effect being 3.7\%. However, if we break this indicator down into its two components - external debt as \% of GNP (LDGNP) and external debt as \% of exports (LDEXP) - we realize that this is not really the case: a one percentage point increase in LDGNP increases the default probability by $0.04 \%$ while a similar increase in LDEXP increases the default probability by a mere $0.01 \%$. So contrary to a widely held belief, the debt levels relative to the resource base (GNP or exports) per se do not appear to be very important determinants of developing country default.

The less important determinants are the current account-GDP ratio (?DP/ ?CAGDPN $=-1.6 \%$ ), the amount of debt (re-)payment arrears relative to total debt $($ ?DP/?LARREDT $=1.5 \%)$ and the M2-international reserves ratio (?DP/?M2IR = $1.3 \%$ ). The least important explanatory variables, eventually, appear to be the amount of credit to the private sector relative to GDP (?DP/?CRPRIV $=0.39 \%)$, the inflation rate in the economy (?DP/?CPIINF2 $=0.35 \%)$, and especially the percentage deviation of the real exchange rate from long-run trend (?DP/?DRER2HP $=0.007 \%$ ).

However, the conclusion regarding the exchange rate misalignment measure DRER2HP has to be qualified. The marginal effect of DRER2HP depends in a more complex fashion on its initial level and on those of all the other variables in the model

\footnotetext{
${ }^{28}$ As suggested by Greene (2000), p. 817, the marginal effect for the dummy

L3DOREDT3ME is calculated as

$\operatorname{Prob}\left(d_{i: t, t+1, t+2}=1 \mid \overline{\mathbf{x}}_{*}, L 3 D O R E D T 3 M E=1\right)-\operatorname{Prob}\left(d_{i: t, t+1, t+2}=1 \mid \overline{\mathbf{x}}_{*}, \quad\right.$ L3DOREDT $\left.3 M E=0\right)$, where $\overline{\mathbf{x}}_{*}$ denotes the means of all other explanatory variables.

${ }^{29}$ The "economic" significance or importance of the determinants is judged by comparing the sizes of the marginal effects in relation to the range (maximum-minimum, see descriptive statistics in table 3) within which the values of these determinants vary in the sample.
} 
than is the case for the other determinants. In effect, equation (12) implies that - for all variables entering the model linearly - all marginal effects change as the point of evaluation of any determinant changes. The order of their economic importance, however, does not depend on the evaluation point. Exactly this is not true for DRER2HP because it enters the model squared. Its marginal effect depends on its own point of evaluation indirectly (through $\alpha+\boldsymbol{\beta}^{\prime} x_{i t}$ ) and directly, as equation (14) shows

$$
\frac{\partial}{\partial D R E R 2 H P_{i t}} \operatorname{Prob}\left(d_{i t}=1\right)=\frac{\exp \left(\alpha+\boldsymbol{\beta}^{\prime} \mathbf{x}_{i t}\right)}{\left[1+\exp \left(\alpha+\boldsymbol{\beta}^{\prime} \mathbf{x}_{i t}\right)\right]^{2}} 2 \cdot D R E R 2 H P \cdot \beta_{D R E R 2 H P} \cdot
$$

The net effect is that the marginal impact of DRER2HP increases as its point of evaluation increases. For instance, at a real currency overvaluation of $40 \%$ (roughly the situation of Argentina at the end of 2000 according to our measure) the marginal impact of DRER2HP is $1.8 \%$ (compared to $0.007 \%$ before, i.e. about 250 times larger!), all other determinants evaluated at their means. At this level of overvaluation, DRER2HP is among the more important determinants, lying in between POLRISK6 $($ ?DP/ ?POLRISK6 $=2.6 \%)$ and CAGDPN $(? \mathrm{DP} /$ ?CAGDPN $=1.7 \%)$.

As to the goodness of fit of Model 1, the McFadden R-squared (0.65) and especially the "percent of correct classifications" (92.05\%) indicate that it fits the data very well. The latter statistic has the following interpretation. When we use the estimated model parameters to calculate the associated default probabilities and classify all countries for which the model predicts a default probability of $50 \%$ or higher as defaults and all predicted probabilities that are lower as non-defaults, we find that in $92.05 \%$ of all cases the model predicts the outcomes that have been actually observed. ${ }^{30}$ In terms of fit, Model 1 outperforms most studies surveyed in table 1, with the exception of the models estimated by Aylward and Thorne (1998) and Balkan (1992).

However, it is especially the "percent of type I errors" (5.28\%) that is promisingly low - lower than the model with the lowest type I error in table 1. Type I errors are classifications where countries actually defaulted but the model predicts a default probability of less than 50\% ("not predicted defaults"). Type II errors, instead, are cases where countries have a predicted probability above $50 \%$ but did not default in reality ("false alarms"). Model 1 yields $12.1 \%$ of type II errors. Considering that for international investors - the multiple costs resulting from a sovereign default are likely to exceed the missed profits in a country that is expected to default but does not, and given that there is always a trade-off between type I and type II errors (i.e. minimizing type I errors increases type II errors, and vice-versa), we retained Model 1 out of several other specifications because it maximizes the percentage of correct classifications while minimizing the percentage of type I errors.

\footnotetext{
${ }^{30}$ The $50 \%$ threshold is somewhat arbitrary. We have chosen the $50 \%$ threshold because it is the one that maximizes the percentage of correct classifications while minimizing type I and type II errors.
} 


\section{Model 2}

As there might be a bias problem as a result of the inclusion of a lagged dependent variable in a logit panel model, we also run a specification of the model where the lagged dependent variable (L3DOREDT3ME) is excluded. ${ }^{31}$ The results are presented in columns 3 and 4 of table 4 ("Model 2"). As expected, the goodness of fit diminishes (Percent correct classifications reduces to $84.63 \%$ from 92.05\%) and the size of a little more than half of the parameters changes considerably. However, with the exception of the variable credit to the private sector as \% of GDP (CRPRIV), all determinants remain statistically significant. Moreover, the statistical significance of a majority of the remaining determinants increases considerably. The variable that gains most in statistical (and second most in economic) significance is the variability of real GNP-per-capita growth (VGNPCAPG2). Moreover, measured by the size of the marginal effect, VGNPCAPG2 is the most important variable in this specification: a one-percentage point increase in the standard deviation of real GNP-per-capita growth increaes the default probability by $5.6 \%$. This seems to be a very interesting result if we consider the fact that only Lee (1991) tested this variable before and found it insignificant.

The two other major statistical significance increases concern the indicator of reserves adequacy (M2IR) and the one for the stock of total arrears relative to total debt in the previous year (LARREDT). Indicators of the adequacy of international reserves have been found to be very important in most previous studies. However, this is the first sovereign default study that tests the M2-international reserves ratio and finds it to be significant. The studies surveyed in table 1 all tested the reserves-imports ratio or the reserves-external debt ratio and almost all found it to be significant. We also started our analysis with the reserves-imports ratio, which was never significant in any specification though.

The stock of arrears gains most in both statistical and economic significance presumably because it picks up part of the information contained in the lagged dependent variable, which was another indicator of past repayment performance in Model 1. All these differences with respect to the studies surveyed in table 1 might be due to the different definition of the dependent variable. Recall that all previous studies defined the dependent variable ("default" or "debt repayment difficulty") in terms of the level of arrears and reschedulings, while we defined it in terms of the changes in these levels.

The variables whose parameters and marginal effects remain roughly the same in size are the current account-GDP ratio (CAGDPN), the lagged debt stock indicator (LDEBST2), CPI inflation (CPIINF) and, to a lesser extent, the M2-international reserves ratio (M2IR), which decreases somewhat. On the other hand, the economic significance of the real exchange rate misalignment variable (DRER2HP)^2, of the political risk indicator (POLRISK6), and of the cost of international credit (LIB6MRE1) reduces by about half.

\footnotetext{
${ }^{31}$ For more details about the nature of this bias, see Heckman (1981) and Hajivassiliou, V. (1994).
} 


\section{Model 3}

The default probabilities implied by Model 1 or Model 2 could now be used as inputs in pricing decisions of sovereign bonds or loans or in credit risk management models. But which of them is more appropriate? As past (re-)payment performance of emerging markets has been found to be a very strong indicator of future (re-)payment performance, we think that the information contained in the lagged dependent variable ( 1 if the country defaulted at least once over the preceding three years, 0 otherwise) is too valuable to be dropped. On the other hand, the significance of the variable "credit to the private sector as a percentage of GDP" (CRPRIV) does not seem to be robust to different specifications, given the results from Model 2. For these reasons a new model - Model 3 (see columns 5 and 6 of table 4) - is specified where CRPRIV is excluded but the lagged dependent variable (L3DOREDT3ME) is included.

As expected, the goodness-of-fit statistics of Model 3 (slightly) deteriorate with respect to Model 1 (but improve compared to Model 2): the McFadden Rsquared diminishes from 0.65 to 0.64 , and the "percent of correct classifications" from 92.05 to 91.71 . However, this deterioration is marginal and only due to the increase in the percent of type II errors from 12.10 to 13.12. In effect, the percent of type I errors diminishes even slightly from 5.28 to 5.20. All indicators remain jointly significant and, apart from the exchange rate misalignment variable (DRER2HP) that is now only significant at the $6 \%$ confidence level, all indicators remain also individually significant at the $5 \%$, or even at the $1 \%$, level. Moreover, comparing the size of the coefficients and of the marginal effects of Model 3 with those of the original Model 1, we observe that they are all broadly similar.

Thus, the conclusion drawn above (sub-section on Model 1) about the order of importance of the determinants remains valid. By far the most important determinant of sovereign default appears to be

- The (re-)payment performance of a country over the recent past (a dummy variable, L3DOREDT3ME, that takes on the value of 1 if the country defaulted at least once over the preceding 3 years and is zero otherwise). Its marginal effect is about $70 \%$.

The other important determinants are

- The cost of international credit (proxied by the real 6-months LIBOR, LIB6MRE1), whose marginal effect is about $8 \%$.

- The variability of real GNP-per capita growth (measured as the standard deviation of real GNP per capita growth over the preceding 7 years, VGNPCAPG2) with a marginal effect of approximately $2.5 \%$.

- Political risks (measured by an index that incorporates the six subcomponents: quality of a country's socio-economic conditions, quality of its investment climate, the degree of corruption, degree of involvement of the military in politics, degree of ethnic tensions, and degree of a government's democratic accountability). This index ranges from 0 (extremely high risk) to 48 (very low risk) and its marginal effect is about $2 \%$.

In the next section, we use the parameters of Model 3 to check its out-ofsample prediction accuracy. In section IV C, eventually, we use Model 3 to calculate the implied 3-years-ahead (cumulative) sovereign default probabilities and we 
compare them with the corresponding 3-year cumulative default rates that correspond to Moody's and Standard \& Poor's long-term foreign currency sovereign credit ratings.

\section{B. Out-of-Sample Prediction Accuracy}

Table 5 lists the 3-year (cumulative) default probabilities (DPs) calculated on the basis of Model 3 for 87 emerging markets over the years 1990 to 2000. The unshaded area refers to the calculated in-sample DPs for the 78 countries used in the estimation (Recall that the time-series dimension of the panel is 1984-97). For the nine yellow shaded countries Azerbaijan, Croatia, Estonia, Kazakhstan, Latvia, Lithuania, Moldova, Slovenia, and Ukraine data was available only from 1998 on, so only the out-of-sample DPs could be calculated for those ones. The yellow shaded columns 1998, 1999, and 2000, finally, contain the calculated out-of-sample DPs for all 87 countries.

The model yields, for instance, a DP for Ecuador in 1996 of $67.6 \%$. This means that with the information on the explanatory variables available as of 1996, the probability of default by Ecuador in 1996 and/or 1997 and/or 1998 was 67.6\%. The default probability for 1997 (default in 1997, 1998 or 1999) increases to 83.8\%.

As of mid-year 2001, we have got limited information available to "back-test" Model 3 forecasts to actual outcomes. The model was estimated with data for the period 1984-1997. From the most recent Global Development Finance 2001 on CDROM (World Bank), we get actual arrears and rescheduling data for the years 1998 and 1999. The most recent EIU CountryData CD-ROM ${ }^{32}$ (Economist Intelligence Unit) provides us with estimates of arrears for the year 2000, and from our own tracking of Paris and London Club rescheduling agreements, we obtain the countries that rescheduled in 2000. Thus, the out-of-sample performance of Model 3 can be tested by comparing the predicted 3-year default probabilities for 1997 with the actual defaults in 1997, 1998, and 1999, and by comparing the predicted default probabilities for 1998 with the actual defaults in 1998, 1999, and 2000. Tables 6 and 7 summarize the results

\section{Out-of-Sample Forecasts (Table 6)}

As explained in section IV A, we use the 50\%-probability threshold to distinguish defaults from non-default observations. The second column of table 6 corresponds to the column for 1997 of table 5. It reports the predicted default probability in 1997, i.e. the probability that a country defaults in 1997, 1998, or 1999. Column 3 of table 6 indicates whether a country effectively defaulted over this period $(=1)$ or not $(=0)$. Similarly, column 6 marks the "false alarms", i.e. the countries that did not default over the three-year period but for which the model predicts a default probability higher than $50 \%$. Column 7 determines the other model error: the actual defaults the model fails to identify. Column 8 indicates the correctly predicted

\footnotetext{
${ }^{32}$ EIU Country Data (Update 34, July 2001) on CD-ROM.
} 
defaults, and the bottom of column 9, eventually, shows false alarms, not predicted defaults and correct classifications in percentage terms.

The last row of table 6 shows that for the period 1997-1999, Model 3 manages to predict $85.9 \%$ (67 out of 78) of defaults and non-defaults correctly. Five actual defaults have not been predicted in 1997 (see dark shaded rows), implying 16.7\% of type I errors. These are Honduras (rescheduling in 1997 but DP is only 9.6\%), Indonesia (rescheduling in 1999 but DP only 6.1\%), Kenya (increase in arrears in 1998 but DP only 8.2\%), Pakistan (increase in arrears in 1998 and rescheduling in 1999 but DP only 8.6\%) and Papua New Guinea (increase of arrears in 1999 but DP only $8.3 \%$ ).

At this point, a remark with respect to the Asian Crisis countries seems warranted. According to column 3 of table 6, Indonesia is the only Asian Crisis country having defaulted over the period 1997-1999. What about South Korea and Thailand? South Korea $(\mathrm{DP}=1.4 \%$ ) did not have any arrears on long-term debt nor did it reschedule any long-term debt over the period, according to Global Development Finance on CD-ROM (1999, 2000, or 2001). Furthermore, neither Moody's Investors Service nor Standard and Poor's, the rating agencies, classified South Korea as in default in these three years. ${ }^{33}$ However, digging a little deeper, one finds that in January 1998 the government of South Korea reached a deal with international banks to reschedule its short-term non-trade debt of US $\$ 24 \mathrm{bn} .{ }^{34}$ If we also considered reschedulings of short-term debt in our default definition, the US\$ $24 \mathrm{bn}$ (equivalent to $17 \%$ of total external debt) would be far beyond the threshold of $2.4 \%$ of total external debt and, hence, South Korea would be classified as in default in 1998. Moreover, considering the details of the deal, ${ }^{35}$ one could legitimately assert that if the rating agencies had strictly applied the second criterion ${ }^{36}$ of their default definition, they would have had to classify Korea as in default in 1998. As to Thailand (DP $=2.8 \%$ ), it turns out that it accumulated US\$1.798bn of new principal arrears to private creditors in 1998. This amount corresponds to about $1.7 \%$ of total external debt, which means that the default threshold of $1.9 \%$ is slightly missed. Eventually, both South Korea and Thailand would certainly have defaulted had they not benefited from large-scale IMF bailout packages.

If we thus considered South Korea $(\mathrm{DP}=1.4 \%)$ and Thailand $(\mathrm{DP}=2.8 \%)$ as having defaulted in 1998, we would obtain two more type I errors. Hence, the percent of correct predictions would diminish to 83.3 from 85.9 and the percent of type I errors would increase to 21.9 from 16.7. Generally, the failure of all three models to predict the Indonesian default and the Thai and South Korean quasi-defaults reflects the problem that these crises could not be foreseen on the basis of any fundamental analysis. To our knowledge, there is currently no model available that is able to predict these crises ex ante. This evidence supports the view that the Asian crises have been of a "self-fulfilling" nature.

\footnotetext{
${ }^{33}$ Moody's Investors Service (1999a), p. 41, and Standard \& Poor's (1999b), p. 17.

${ }^{34}$ Financial Times (1998), and World Bank (2000), p. 620.

${ }^{35}$ According to the Financial Times (1998), ,[the deal] set interest rates at 225, 250 and 275 basis points over the six-month LIBOR... Banks had initially pressed for a 400 basis point rate."

${ }^{36}$ See section III A.
} 
The reason for the six (i.e. 12.5\%) "false alarms" Brazil (DP $=80.1 \%)$, Guatemala (DP $=86.7 \%$ ), Jamaica $(81.8 \%)$, Panama ( $\mathrm{DP}=81.0 \%)$, Poland $(\mathrm{DP}=$ $61.2 \%$ ), and Sri Lanka (DP $=79.0 \%$ ) is always the same: the weight of past repayment performance (L3DOREDT3ME). They all defaulted at least once over the preceding three years (i.e. 1994-1996) but then became "good" debtors over the period under consideration.

\section{Out-of-Sample Forecasts (Table 7)}

Table 7 is analogous to table 6 except that it tests the out-of-sample performance of Model 3 for the forecast period 1998-2000 and for the nine additional countries mentioned above, i.e. for 87 emerging markets on the whole. ${ }^{37}$ The last row shows that in this case, Model 3 predicts $86.2 \%$ (75 out of 87 ) of defaults and nondefaults correctly - a performance which is roughly the same as before. There are also five type I errors $(16.1 \%)$ of which three (Kenya, Pakistan, Papua New Guinea) are the same as before. The two other not-predicted defaults are those of Kazakhstan (significant increase in arrears in 1999 but DP in 1998 of only 7.4\%) and Zimbabwe (new arrears in 2000 but DP in 1998 of "only" 15.2\%). Note than none of these type I errors concern the nine additional countries included in this out-of-sample test.

Indonesia's 1999 default (rescheduling) is predicted this time, the default probability in 1998 being $95 \%$. A quick look at the determinants reveals an interesting result. The main determinant responsible for this high DP is our exchange rate misalignment variable (DRER2HP), indicating that - due to the dramatic devaluation of the Indonesian Rupiah in 1998 - the Indonesian currency was about 64\% undervalued in that year. Recall the discussion of equation (14) in section IV A. At such a serious level of misalignment, DRER2HP becomes a very important determinant of the sovereign default probability because it enters (the already nonlinear!) equation (9'") squared. Hence, it is also the reduction of this undervaluation to about 3\% in 1999, which explains the sharp fall in the DP in 1999 to $10.9 \%$ (see table $5)$.

The third-last row of table 7 shows that the $1998 \mathrm{DP}$ forecasts produce exactly the same percentage of type II errors as the 1997 DP forecasts, namely $12.5 \%$. In absolute terms, this is one more false alarm compared to the six ones in table 6 . Two of them are the same as before (Jamaica and Sri Lanka). The five new false alarms pertain to Algeria $(\mathrm{DP}=81.5 \%)$, Bulgaria $(\mathrm{DP}=73.6 \%)$, Croatia $(\mathrm{DP}=88.8 \%)$, Dominican Republic ( $\mathrm{DP}=75.9 \%)$, and Peru ( $\mathrm{DP}=84.8 \%)$. The reason for these false alarms is the same again: the countries defaulted (at least once) over the three years 1995 to 1997 but then serviced their debts according to schedule over the period 1998-2000. Note that out of the nine "out-of-sample countries", the misclassification of Croatia is the only type II error affecting those countries. Finally, as far as South Korea $(\mathrm{DP}=1.5 \%)$ and Thailand $(\mathrm{DP}=2.4 \%)$ are concerned, the same remarks as in the preceding section apply (i.e. if we taxed them as defaults in 1998, we would have two more type I errors, which would reduce the percentage of correct classifications to 83.9 from 86.2 ; the percent of type I errors would increase to 21.2 from 16.1).

\footnotetext{
${ }^{37}$ The nine additional countries are the yellow shaded ones of table 5, i.e. Azerbaijan, Croatia, Estonia, Kazakhstan, Latvia, Lithuania, Moldova, Slovenia, and Ukraine.
} 
On the basis of two years of out-of-sample forecasts for 78 countries in the first exercise and 87 in the second, we conclude that the out-of-sample prediction accuracy of Model 3 is surprisingly good: the percent of correct classifications is 86.1 on average, compared to an in-sample performance of $91.7 \%$. The percent of type I errors out-of-sample is 16.4 on average, compared to $5.2 \%$ in-sample. Finally, we have an average of only $12.5 \%$ of type II errors out-of-sample, which even beats the $13.1 \%$ of type II errors in-sample. Unfortunately, we cannot compare these performance rates to the empirical studies surveyed in section II and table 1 as none of them performs out-of-sample performance tests.

\section{Comparison of Estimated Default Probabilities vs. Rating Agencies' Default Rates}

\section{Sovereign Credit Ratings and Corresponding Default Rates}

The default probabilities calculated from Model 3 and summarized in table 5 (i.e. the probabilities that emerging market countries default within a three-year horizon on their foreign currency denominated debt) can now be compared indirectly with the information conveyed by the long-term foreign currency sovereign credit ratings that are publicly available on the websites of the two leading rating agencies, Moody's Investors Service ("Moody's) and Standard and Poor's ("S\&P' s"). 38 According to S\&P's, long-term foreign currency sovereign credit ratings "are an assessment of each government's capacity and willingness to repay [foreign currency denominated, long-term] debt according to its terms". ${ }^{39}$ Moody's broadly similar rating concept, called "country ceiling for long-term foreign currency bonds and notes", is "based upon the default risk for medium and/or long-term debt obligations issued by a national government (denominated in foreign currency)". 40

How can Model 3 default probabilities be compared to these letter ratings, ranging from triple-A (i.e. Aaa for Moody's, AAA for S\&P's) all the way down to single-C? It is not to those letter ratings directly that the calculated default probabilities can be compared, but they can be compared to the 3-year cumulative default rates associated with each rating grade.

Table 8 presents Moody's and S\&P's rating scales along with the associated 3year cumulative default rates. Both rating agencies compile such cumulative default rates over periods of one up to 20 years. ${ }^{41}$ For example, the average 3 -year cumulative

\footnotetext{
${ }^{38}$ For Moody's Investors Service's country (formerly "sovereign") ceilings, see http://www.moodys.com/moodys/cust/RatingAction/rlist.asp?busLineId=7.

For Standard and Poor's sovereign ratings, see http://www.standardandpoors.com/RatingsActions/RatingsLists/Sovereigns/SovereignsRatingsList.html.

Alternatively, a third globally operating commercial provider of credit ratings is FitchIBCA, see http://www.fitchibca.com/corporate/sectors/issuers_list_corp.cfm?sector_flag=5\&marketsector=1\&detail=.

${ }^{39}$ See Standard \& Poor's (1997), p. 21.

${ }^{40}$ See Moody's Investors Service (1995), p. 5.

${ }^{41}$ See, for instance, Standard \& Poor's (2001a) and Moody's Investors Service (2001).
} 
default rate for the rating grade $\mathrm{BB}+(\mathrm{S} \& \mathrm{P}$ 's) equals $3.15 \%$. That is the historical average number of obligors that defaulted within the three years of being assigned the rating $\mathrm{BB}+$, expressed as a percentage of the total number of companies with a $\mathrm{BB}+$ rating over the same three years.

All major banks use credit ratings and, especially, the corresponding default rates to price bonds and loans, to feed their credit risk management models, and to determine their complex customer and country exposure limits. Moreover, according to the current version of the New Basel Capital Accord ${ }^{42}$, banks will be allowed to use credit ratings and the corresponding default rates to determine the amount of regulatory capital they have to set aside against their credit risks. Thus, credit ratings and associated default rates play a crucial role in international capital allocation.

The central problem for emerging market sovereign credit analysis is that these are corporate default rates, i.e. based on rated companies that have defaulted in the past. There are no reliable default rates available for sovereign borrowers. The reason is that only very few rated sovereigns have defaulted since World War II when the rating agencies started to collect the relevant data. ${ }^{43}$ In other words, it is not that few sovereigns have defaulted since World War II - proof of which is figure 1 - but that the governments which defaulted (mostly low income/less developed countries) were not rated by the rating agencies and, vice-versa, that those governments which had a rating assigned by either Moody's and/or S\&P's (mostly highincome/industrialized countries) did not default. ${ }^{44}$ Thus, not only is the population of potentially "ratable" sovereigns small (around 200) compared to that of companies (tens if not hundreds of thousands), but also the sample of rated sovereigns is not representative. As a consequence, default rates for sovereign rating grades are unreliable. In effect, most of them are (still) zero!

For want of better alternatives, it is thus common practice among bank credit risk managers to assume that corporate and sovereign default rates are similar or, as one of the rating agencies puts it: "Standard \& Poor's expects sovereign rating stability and default probability to converge with its corporate ratios over time as the number of sovereign observations increases, as one would expect given that both groups use the same rating definitions." ${ }^{45}$ However, given the fundamentally different

\footnotetext{
${ }^{42}$ Basel Committee on Banking Supervision (2001).

${ }^{43}$ Since World War II (and until December 2001), only five governments rated by S\&P's have defaulted on long-term (local and foreign currency, bond and bank) debt: Venezuela (1983-90, 1995-1998), Indonesia (1998-2000), Pakistan (1998-1999), Russia (1998-2000), and Argentina (2001) (Standard \& Poor's (2001b), p. 89, and author's own tracking). During the same period, eight sovereigns rated by Moody's have defaulted on publicly held long-term (local and foreign currency) debt: Argentina (1989), Pakistan (1998), Russia (1998), Venezuela (1998), Ecuador (1999), Ukraine (2000), Peru (2000), and Argentina (2001) (Moody's Investors Service (1999a), p. 6, and author's own tracking).

${ }^{44}$ Moreover, it appears that when rated sovereigns default, they default first on un-rated debt. Only if there are no alternatives, they default on rated, publicly traded (bond) debt. However, default rate statistics take account of a sovereign's ability to "selectively default" by focusing on "issuer" ratings and not on "issue" ratings. For more information about rating definitions and methodologies, see rating agencies' websites.

${ }^{45}$ Standard \& Poor's (2001b), p. 89.
} 
legal status of sovereign and corporate borrowers, and the fundamental difference between sovereign and corporate "solvency", this assumption seems more than doubtful.

The question therefore is: could sovereign default probabilities such as those derived in the present paper (see table 5) be more appropriate measures of the likelihood of a sovereign default than rating agencies' corporate default rates? This question is not easily answered. For the time being, let's assume they are and proceed to the comparison of the two sets of default risk measures. Tables 9 and 10 list Model 3 default probabilities (DPs) along with Moody's and S\&P's “average 3-year cumulative default rates by letter rating" (DRs) for two sets of countries at two moments in time:

1) Table 9 shows Model 3 DPs and agencies' DRs at the end of 1996 (i.e. the last observations available before the outbreak of the Asian crisis) for those 40 countries for which Model 3 DPs could be calculated and which were rated at that time by either Moody's or S\&P's. ${ }^{46}$

2) Table 10 displays Model 3 DPs and agencies' DRs at the end of 2000 for those 25 emerging markets that had the largest liabilities (in US\$ terms) towards BIS reporting banks in $2000 .{ }^{47}$

\section{Before the Asian Crisis (Table 9)}

Table 9 shows the situation for the 40 countries rated by either Moody's or S\&P's before the outbreak of the Asian crisis, i.e. at the end of 1996 (or the beginning of 1997). Of the 29 countries rated by both Moody's and S\&P's, 79\% (i.e. 23) had lower 3-year cumulative default rates than estimated 3-year sovereign default probabilities. Moody's had rated 37 of those 40 countries at the time (i.e. $93 \%$ ). 30 of these 37 sovereigns (i.e. 81\%) had default rates that were lower than Model 3 DPs. Standard \& Poor's had assigned sovereign credit ratings to 32 (i.e. 80\%) of them. Their default rates, however, were lower than Model 3 DPs for $84 \%$ of the countries rated (27 out of 32). For only three of the 40 countries - Mexico, Romania, and Venezuela - Model 3 DPs lie somewhere in between Moody's and S\&P's default rates.

The results are particularly interesting for the Asian crisis countries Indonesia, Korea, Malaysia and Thailand as well as for Russia (grey shaded countries). For all these countries, the default rates implied by their ratings at the end of 1996 seem overly optimistic. For Indonesia, Korea and Malaysia, Model 3 default probabilities at the end of 1996 were about 4 to 5 times higher than Moody's default rates and about 8 to 11 times higher than S\&P's default rates. For Russia, the calculated DP was about 15 times higher than S\&P's default rate and almost 20 times higher than Moody's default rate. Thailand's Model 3 DP was almost 26 times higher than both Moody's

\footnotetext{
${ }^{46}$ Model 3 DPs can be calculated in 1996 for 77 of the 78 countries (except for South Africa).

${ }^{47}$ To calculate the default probabilities as of end 2000, estimates from EIU CountryData (Update 28, January 2001) on CD-ROM were used for all indicators except for debt rescheduling arrangements. Data on the latter was taken from the Institute of International Finance's "Survey of Debt Restructuring by Private Creditors" and "Survey of Debt Restructurings by Official Creditors".
} 
and S\&P's default rate. To be fair, though, one has to acknowledge that in absolute terms, Model 3 default probabilities were also relatively low for all four Asian Crisis countries. However, Russia's sovereign default probability was very high at the end of 1996 (99.7\%). This result is mainly due to the fact that Russia had defaulted on external debt in almost every year since 1990 .

\section{At the Beginning of 2001 (Table 10)}

Table 10 makes a similar assessment but this time for the 25 emerging market countries with the largest liabilities to foreign banks in 2000. More generally, these are also the emerging markets that have received the most foreign capital flows of any form in recent years. The rationale for the choice of this sample is that sovereign credit ratings - and the associated estimates of credit risk - play their potentially most important role in the international allocation of bank finance and portfolio debt (i.e. sovereign and corporate bonds) flows. The fact that bank debt has been shown to be the most volatile form of foreign finance in emerging markets in recent years, ${ }^{48}$ may very well be related to the way international banks rate emerging market sovereigns. Similarly, the large rating downgrades of Asian sovereigns by Moody's and S\&P's during the Asian Crisis (the so-called "rating crisis", see Jüttner and McCarthy (2000)) may help explain the volatility of portfolio debt flows in recent years.

24 of the 25 emerging markets in table 10 are rated by both Moody's and Standard \& Poor's. Saudi Arabia is only rated by Moody's. Compared to the situation before the Asian crisis, the picture is somewhat less extreme for Moody's but even more pronounced for S\&P's. Moody's default rates are lower than Model 3 DPs for $76 \%$ of the countries (19 out of 25), i.e. for all except Brazil, India, the Philippines, Turkey, and Venezuela. S\&P's default rates are lower for fully 22 of the 24 rated countries (i.e. 92\%), i.e. for all except the Philippines and Venezuela. For only two of the 24 largest bank debtor nations rated by both S\&P's and Moody's (i.e. 8\%) - the Philippines and Venezuela - Model 3 sovereign default probabilities are lower than both agencies' default rates. Again three countries - Brazil, India, and Turkey this time - have predicted DPs that are in-between Moody's and S\&P's default rates. This implies that - again as before! - 79\% of the countries rated by both rating agencies (19 out of 24) had 3-year cumulative default rates that were lower than the 3-year default probabilities estimated by Model 3 .

Argentina might be an interesting case in the light of its recent default (November 2001). The predicted 3-year DP at the beginning of 2001 (i.e. with data on the determinants available as of end 2000) was 18.15\%. This means that Model 3 did not predict the Argentine default one year ahead. However, compared to the default rates implied by Moody's and S\&P's long-term FX ratings (14.81\% and 6.79\%), the outlook conveyed by Model 3 DPs was clearly more pessimistic. Turkey is another important emerging market that gives rise to concern among international financial market participants at the moment. Here, the results are more in line with each other. The Model 3 default probability forecast for the period 2000-2002 is about $14.4 \%$, which is slightly smaller than the $14.8 \% 3$-year cumulative default rate implied by

\footnotetext{
${ }^{48}$ See, for example, International Monetary Fund (1998), pp. 12-16.
} 
Moody's B1 rating, but somewhat larger than the 10.4\% 3-year default rate implied by S\&P's B+ rating.

The conclusions from this comparison are drawn in the next section (see subsection entitled Adequacy of rating agencies' "sovereign" default rates).

\section{Conclusions, Policy IMPlications ANd AgENDA FOR Future ReSEARCH}

The paper made an attempt at estimating sovereign default probabilities with a logit panel model, using data for 78 emerging markets over the period 1984-1997. In contrast with the existing literature, the dependent variable ("sovereign default") is defined with respect to the changes in the levels of debt arrears and amounts of debt rescheduled as compared to the levels themselves. Compared to the existing studies, the estimated models fit the data equally well or better, achieving an average insample prediction accuracy of about $91 \%$, with slightly over 5\% type I errors and about $13 \%$ of type II errors. The out-of-sample performance is also quite promising: the percentage of correct classifications is $86 \%$ with about $16.5 \%$ type I errors and $12.5 \%$ type II errors. The paper provides new empirical evidence about the importance of international and country-specific macroeconomic and political determinants of sovereign default. It then compares the estimated sovereign default probabilities with the default rates correspond-ding to the sovereign credit ratings of the two leading rating agencies, Moody's Investors Service and Standard \& Poor's. The results obtained from the analysis of our sample suggest conclusions in three main areas: (1) with respect to the determinants of sovereign default, (2) with respect to the adequacy of rating agencies "sovereign" default rates and, (3) with respect to questions requiring further research.

\section{Sovereign default determinants}

By far the most important country-specific explanatory variable appears to be the repayment performance of a country over the recent past: a sovereign that defaulted (at least once) over the preceding three years has a default probability that is fully 70 percentage points higher than a sovereign with an unblemished debt-servicing track record over the same period. The two most important other country-specific determinants are the variability of real GNP-per capita growth and a political risk index - both variables that have either not been used in previous studies or were found to be insignificant: a $100 \mathrm{bp}$-increase in the volatility of the real GNP-per capita growth rate increases the default probability by about $250 \mathrm{bp}$, while a one-unit increase in political risk increases default risk by $200 \mathrm{bp} .{ }^{49}$ The other significant determinants - in decreasing order of importance - are: the percentage deviation of the real exchange rate from long-run trend, the current account/GDP ratio, the amount of arrears accumulated in the previous year, the M2/interntional reserves ratio, the CPI inflation rate, and a debt stock indicator (comprised of the debt/GDP and the debt/exports ratio).

Emerging market economies wishing to have access to international capital markets have an interest in minimizing their default probability. Failing to do so

\footnotetext{
${ }^{49}$ All marginal effects are calculated at the means of the explanatory variables, see equation (12).
} 
implies that they are confronted with severe borrowing restrictions ${ }^{50}$ or unsustainably high borrowing costs (the other side of the same coin). The results thus suggest that the typical emerging market government has an interest (in that order of importance):

- to keep a good track record as a borrower, i.e. not to default on external obligations and, in case a default is inevitable, to keep amounts of defaulted obligations as low as possible

- to try to limit fluctuations in the growth rate of per capita income

- to limit political risks in the country, in particular

$>$ to limit corruption, ethnic tensions, and the involvement of the army in politics and

$>$ to improve the investment climate, socio-economic conditions, and the government's democratic accountability.

- to implement proper exchange rate policies by avoiding large deviations of the real exchange rate from long-run trend

- to limit the speed with which it accumulates external liabilities (i.e. to limit the size of its current account deficit compared to its GDP)

- to keep a certain cushion of international reserves relative to the money supply (This seems to be especially relevant for countries with a relatively open capital account, an unstable money demand or a weak banking system, where the potential for capital flight is high. ${ }^{51}$ )

- to maintain price stability by means of appropriate fiscal and monetary policies, and

- to limit the size of its external debt stock compared to its total income (GNP) and its export earnings.

In contrast to the existing literature, we also find that the cost of international credit - a global factor - is a very important default determinant: a one-percentage point increase in the real 6-month LIBOR rate increases the default probability of the average emerging market sovereign by about 800 basis points.

\section{Adequacy of rating agencies" "sovereign" default rates}

We compared the rating agencies' corporate default rates (which agencies use as proxies for the non-existing sovereign default rates) that are associated with each rating grade with the estimated sovereign default probabilities at two (arbitrary) points in time: at the end of 1996 (i.e. before the Asian Crisis) and at the end of 2000. The comparison showed that in both years, $79 \%$ of the countries rated by both agencies had substantially lower 3-year default rates than estimated 3-year default probabilities. Moreover, in the sample analyzed, S\&P's default rates were lower on average than Moody's default rates.

These results suggest the following conclusions. First, on an empirical level, it appears that rating agencies' (corporate!) default rates considerably underestimate (sovereign!) default risk over a three-year horizon. This finding is consistent with the observation that bonds issued by emerging market sovereigns usually trade at higher yield spreads than similarly rated US corporate bonds (see, e.g., International

\footnotetext{
${ }^{50}$ For many developing countries, this means exclusion from (private) international capital markets.

${ }^{51}$ See International Monetary Fund (2000a), p. 14.
} 
Monetary Fund (2000b)). This differential in yield spreads could thus be explained by the higher default probability of emerging market sovereigns (as opposed to a greater loss-given-default rate) compared to US corporates. Another way of interpreting the results from the comparison is that rating agencies' sovereign ratings are generally too high. If the results based on this sample turned out to be representative, both interpretations would imply that the corporate default rates associated with a given (corporate) rating grade do not appear to be adequate proxies for the sovereign default probabilities associated with the same (sovereign) rating grade. Further research is needed to assess whether the leading market providers of sovereign credit ratings systematically underestimate sovereign default risk.

Second, on a more theoretical level, a systematic underestimation of sovereign default risk in emerging markets by rating agencies, internationally operating banks and other international investors would lead (or could have led) to an underestimation of credit risk, hence to an under-pricing of foreign finance and, hence, to excessive foreign (bank and portfolio debt) capital inflows in these markets. Subsequently, when some unexpected global or country specific shock (e.g. an unexpected policy shift such as a no-bailout, a devaluation or a default -, an increase in political instability, or the bursting of a domestic asset price bubble) triggers a reassessment of the effective (market and credit) risks involved, internal and external ratings ${ }^{52}$ may be rapidly downgraded and foreign (short-term) finance flows out as international investors struggle to reduce their exposures in these countries now perceived to be more risky. Moreover, a vicious circle of internal and external rating downgrades, capital outflows and deteriorating expected fundamentals may develop, resulting in a self-fulfilling crisis. The liquidity crisis that follows the harum-scarum capital outflows may eventually lead to a full-blown financial (i.e. balance-of-payments and/or currency and/or debt and/or banking) crisis, which in turn is likely to result in the serious welfare losses documented in chapter 7 of Goldstein et al. (2000) and, more recently, in Hutchison and Neuberger (2001). In the light of these potential consequences, an appropriate assessment of sovereign default risk by rating agencies and international investors appears crucial.

\section{Agenda for future research}

Two issues are further investigated. First, I plan to relax the simplifying assumption of equation errors being identically and independently distributed across time and across countries in order to verify if the conclusions drawn are robust to this kind of specification change. Relaxing this assumption necessitates proper dealing with possible state dependence within a cross-sectional unit, and unobserved heterogeneity across units. Unfortunately, estimating such dynamic discrete choice models is not an easy task. However, with the recent publication of the work by Honore and Kyriazidou (2000), this task appears to be feasible now.

Second, I plan to examine a little more in depth what the rating agencies' sovereign (long-term, foreign currency) credit ratings really measure. Beyond the classic reference in this field, Cantor and Packer (1996), there are unfortunately only few more recent empirical papers on this issue. ${ }^{53}$ Unfortunately, too, their conclusions

\footnotetext{
52 "Internal" refers to bank-internal ratings, while "external" refers to agency ratings.

${ }^{53}$ See, for instance, Jüttner and McCarthy (2000), Monfort and Mulder (2000), and Mulder and Perrelli (2001).
} 
are not uniform as they use very different samples. Moreover, contrary to their results, our own preliminary investigations ${ }^{54}$ (using a maximum of countries rated, not only some 20 emerging markets) show that one of the most important driving factors of sovereign credit ratings appear to be PPP adjusted GDP per capita levels - a

somewhat puzzling result, at least at first sight. Is it possible that, at the end of the day, the rating agencies' sovereign credit ratings simply reflect standards of living or levels of development?

${ }^{54}$ See Peter (2002). 


\section{REFERENCES}

Arellano, Manuel, and Bo Honore, 2001, "Panel Data Models: Some Recent Developments," in Handbook of Econometrics, Vol. 5, ed. by James J. Heckman and Edward Leamer (Amsterdam: North Holland).

Arora, Vivek B., 1993, "Sovereign Debt: A Survey of Some Theoretical and Policy Issues," IMF Working Paper N56 (Washington: International Monetary Fund).

Avery, Robert B., and Eric O'N Fisher, 1992, "Empirical models of debt-rescheduling with sovereign immunity," in Country Risk Analysis. A Handbook, ed. by Ronald L. Solberg (London: Routledge), pp. 100-117.

Avramovic, Dragoslav, 1964, Economic Growth and External Debt (Baltimore, Maryland: Johns Hopkins Press).

Aylward, Lynn, and Rupert Thorne, 1998, "An Econometric Analysis of Countries' Repayment Performance to the International Monetary Fund," IMF Working Paper $\mathrm{N}^{\circ} 32$ (Washington: International Monetary Fund).

Babbel, David F., 1996, "Insuring Sovereign Debt Against Default," World Bank Discussion Paper N³28 (Washington: The World Bank).

Balkan, Erol, 1992, "Political Instability, Country Risk and Probability of Default," Applied Economics, Vol. 24 (9), pp. 999-1008.

Basel Committee on Banking Supervision, 2001, "The New Basel Capital Accord," Consultative Document, January (Basel: Bank for International Settlements).

Beim, David O., and Charles W. Calomiris, 2001, Emerging Financial Markets (New York: McGraw-Hill/Irvin).

Berg, Andrew, and Catherine Pattillo, 1998, "Are Currency Crises Predictable? A Test," IMF Working Paper $N^{\circ} 154$ (Washington D.C.: International Monetary Fund).

Berg, Andrew, and Jeffrey Sachs, 1988, "The Debt Crisis: Structural Explanations of Country Performance," Journal of Development Economics, Vol. 29, pp. 271306.

Callier, Philippe, 1985, "Further results on countries' debt-service performance: The relevance of structural factors," Weltwirtschaftliches Archiv, Vol. 121, pp. 105115.

Calvo, Guillermo A, 1996, "Capital Flows and Macroeconomic Management: Tequila Lessons," International Jouranal of Finance and Economics, Vol. 1 (July), pp. 207-224.

Calvo, Guillermo A, and Enrique G Mendoza, 1996, "Mexico's balance of payments crisis: a chronicle of a death foretold," Journal of International Economics, Vol. 41, pp. 235-264.

Cantor, Richard, and Frank Packer, 1996, "Determinants and Impact of Sovereign Credit Ratings," FRBNY Economic Policy Review, Vol. (October), pp. 37-52.

Ciarrapico, Anna Micaela, 1992, Country Risk: A Theoretical Framework of Analysis (Aldershot: Dartmouth).

Citron, Joel-Tomas, and Gerald Nickelsburg, 1987, "Country Risk and Political Instability," Journal of Development Economics, Vol. 25, pp. 385-392.

Cline, William, 1984, International debt: Systemic risk and policy response (Washington D.C.: Institute of International Economics).

Cline, William R., 1995, International Debt Reexamined (Washington D.C.: Institute for International Economics).

Cohen, Daniel, 1991, Private Lending to Sovereign States: A Theoretical Autopsy (Cambridge, MA: MIT Press). 
Corsetti, Giancarlo, Paolo Pesenti, and Nouriel Roubini, 1998, "Fundamental Determinants of the Asian Crisis: A Preliminary Empirical Assessment," Unpublished manuscript (New Haven, New York, New York: Yale University and University of Bologna, Federal Reserve Bank of New York and NBER, New York University and NBER).

Demirguc-Kunt, Asli, and Enrica Detragiache, 1998, "The Determinants of Banking Crises in Developing Countries," IMF Staff Papers, Vol. 45 (1), pp. 81-109.

Demirguc-Kunt, Asli, and Enrica Detragiache, 1999, "Monitoring Banking Sector Fragility: A Multivariate Logit Approach," IMF Working Paper N ${ }^{\circ} 147$

(Washington: International Monetary Fund).

Detragiache, Enrica, and Antonio Spilimbergo, 2000, "Crises and Liquidity: Evidence and Interpretation," Unpublished manuscript (Washington: International Monetary Fund).

Eaton, Jonathan, and Raquel Fernandez, 1995, "Sovereign Debt," in Handbook of International Economics, Vol. III, ed. by Gene Grossman and Kenneth Rogoff (Amsterdam: Elsevier), pp. 2031-2077.

Eaton, Jonathan, and Marc Gersovitz, 1981, "Debt with potential repudiation: Theoretical and empirical analysis," Review of Economic Studies, Vol. 48 (February), pp. 289-309.

Eaton, Jonathan, Mark Gersowitz, and Joseph E. Stiglitz, 1986, "The Pure Theory of Country Risk," European Economic Review, Vol. 30 (June), pp. 481-513.

Edwards, Sebastian, 1984, "LDC Foreign Borrowing and Default Risk: An Empirical Investigation, 1976-80," American Economic Review, Vol. 74 (4), pp. 726-734.

Eichengreen, Barry, Andrew Rose, and Charles Wyplosz, 1996, "Contagious Currency Crises," Scandinavian Economic Review, Vol. 98 (4), pp. 463-484.

Feder, Gershon, and Richard E. Just, 1977, "A Study of Debt Servicing Capacity Applying Logit Analysis," Journal of Development Economics, Vol. 4, pp. 2538.

Feder, Gershon, Richard E. Just, and Knud Ross, 1981, "Projecting debt-servicing capacity of developing countries," Journal of Financial and Quantitative Analysis, Vol. 16 (5), pp. 651-669.

Feder, Gershon, and Lily V. Uy, 1985, "The Determinants of International Creditworthiness and Their Policy Implications," Journal of Policy Modeling, Vol. 7 (1), pp. 133-156.

Financial Times, 1998, Crisis Countdown - Korea: May 1997 to July 1998 (in: Financial Times Special Report: Asia in Crisis) (http://specials.ft.com/ln/specials98/q2ada.htm).

Frank, Charles Raphael, and William R Cline, 1971, "Measurement of debt servicing capacity of developing countries: An application of discriminant analysis," Journal of International Economics, Vol. 1, pp. 327-344.

Frankel, Jeffrey A., and Andrew K. Rose, 1996, "Currency Crashes in Emerging Markets: An Empirical Treatment," Journal of International Economics, Vol. 41, pp. 351-366.

Goldfajn, Ilan, and Rodrigo O. Valdes, 1997, "Are Currency Crises Predictable?," IMF Working Paper $\mathrm{N}^{\circ} 159$ (Washington: International Monetary Fund).

Goldstein, Morris, Carmen M. Reinhart, and Graciela L. Kaminsky, 2000, Assessing Financial Vulnerability: An Early Warning System for Emerging Markets (Washington D.C.: Institute for International Economics).

Greene, William H., 2000, Econometric Analysis (Upper Saddle River NJ: Prentice Hall, 4th ed.). 
Hajivassiliou, Vassilis, 1989, "Do the Secondary Markets Believe in Life After Debt?," World Bank Policy Planning and Research Working Paper N ${ }^{\circ} 252$ (Washington: The World Bank).

Hajivassiliou, Vassilis, 1994, "A Simulation Estimation Analysis of the External Debt Crises of Developing Countries," Journal of Applied Econometrics, Vol. 9 (2), pp. 109-113.

Hajivassiliou, Vassilis A, 1987, "The External Debt Repayment Problems of LDC's: An Econometric Model Based on Panel Data," Journal of Econometrics, Vol. 36, pp. 205-230.

Haque, Nadeem U., Nelson Mark, and Donald J. Mathieson, 1998, "The Relative Importance of Political and Economic Variables in Creditworthiness Ratings," IMF Working Paper $\mathrm{N}^{\circ} 46$ (Washington D.C.: International Monetary Fund).

Haque, Nadeem Ul, Manmohan S. Kumar, Nelson Mark, and Donald J. Mathieson, 1996, "The Economic Content of Indicators of Developing Country Creditworthiness," IMF Staff Papers, Vol. 43 (4), pp. 688-724.

Heckman, James J, 1981, "Statistical Models for Discrete Panel Data," in Structural Analysis of Discrete Data with Econometric Applications, ed. by Charles Manski and Daniel McFadden (Cambridge, MA: MIT Press), pp. 114-178.

Honohan, Patrick, 1997, "Banking System Failures in Developing and Transition Countries: Diagnosis and Prediction," BIS Working Papers N³9 (Basle: Bank for International Settlements).

Honore, Bo E, and Ekaterini Kyriazidou, 2000, "Panel Data Discrete Choice Models with Lagged Dependent Variables," Econometrica, Vol. 68 (4), pp. 839-874.

Hutchison, Michael M., and Ilan Neuberger, 2001, "Output Costs of Currency and Balance of Payments Crises in Emerging Markets," Unpublished manuscript (Santa Cruz: University of California, Santa Cruz, September).

International Monetary Fund, 1998, International Capital Markets - Developments, Prospects, and Key Policy Issues (Washington D.C.: International Monetary Fund).

International Monetary Fund, 2000a, "Debt- and Reserve-Related Indicators of External Vulnerability," Prepared by the Policy Development and Review Department in consultation with other Departments, March 23 (Washington D.C.: International Monetary Fund).

International Monetary Fund, 2000b, "Emerging Market Financing - Quarterly Report on Developments and Prospects," Third Quarter 2000 (Washington D.C.: International Monetary Fund).

International Monetary Fund, 2001, Anticipating Crises: Model Behavior or Stampeding Herds (Transcript of an Economic Forum, November 1st) (http://www.imf.org/external/np/tr/2001/tr011101a.htm).

Jüttner, D. Johannes, and Justin McCarthy, 2000, "Modelling a Rating Crisis," Unpublished manuscript (Sydney: Macquarie University).

Kaminsky, Graciela L., 1998, "Currency and Banking Crises: A Composite Leading Indicator," Unpublished manuscript (Washington: Board of Governors of the Federal Reserve System).

Kaminsky, Graciela L., Saul Lizondo, and Carmen M. Reinhart, 1997, "Leading Indicators of Currency Crises," IMF Working Paper $N^{\circ} 79$ (Washington: International Monetary Fund).

Kaminsky, Graciela L., and Carmen M. Reinhart, 1999, "The Twin Crises: The Causes of Banking and Balance of Payments Problems," American Economic Review, Vol. 3 (89), pp. 473-500. 
Lee, Suk Hun, 1991, "Ability and willingness to service debt as explanation for commercial and official rescheduling cases," Journal of Banking and Finance, Vol. 15, pp. 5-27.

Lee, Suk Hun, 1993, "Are the credit ratings assigned by bankers based on the willingness of LDC borrowers to repay?," Journal of Development Economics, Vol. 40, pp. 349-359.

Li, Carmen A., 1992, "Debt Arrears in Latin America: Do Political Variables Matter?," Journal of Development Studies, Vol. 28 (4), pp. 668-688.

Maddala, G. S., 1983, Limited-dependent and qualitative variables in econometrics (Cambridge: Cambridge University Press).

Marashaden, Omar, 1997, "A Logit Model to Predict Debt Rescheduling by Less Developed Countries," Asian Economies, Vol. 26 (March), pp. 25-34.

McDonald, Donogh, 1982, "Debt Capacity and Developing Country Borrowing: A Survey of the Literature," IMF Staff Papers, Vol. 29, pp. 603-646.

McFadden, Daniel, Richard Eckaus, Gershon Feder, Vassilis Hajivassiliou, and Stephen O'Connell, 1985, "Is There Life After Debt? An Econometric Analysis of the Creditworthiness of Developing Countries," in International Debt and the Developing Countries, ed. by Gordon Smith and John Cuddington (Washington D.C.: The World Bank), pp. 179-209.

Monfort, Brieuc, and Christian Mulder, 2000, "Using Credit Ratings for Capital Requirements on Lending to Emerging Market Economies: Possible Impact of a New Basel Capital Accord," IMF Working Paper N ${ }^{\circ} 69$ (Washington D.C.: International Monetary Fund).

Moody's Investors Service, 1995, "Sovereign Risk: Bank Deposits vs. Bonds," Special Comment, October (New York: Moody's Investors Service).

Moody's Investors Service, 1999a, "Historical Default Rates of Corporate Bond Issuers, 1920-1998," Special Comment, January (New York: Moody's Investors Service).

Moody's Investors Service, 1999b, "Moody's Sovereign Ratings: A Ratings Guide," Special Comment, March (New York: Moody's Investors Service).

Moody's Investors Service, 2000, "Historical Default Rates of Corporate Bond Issuers, 1920-1999," Special Comment, January (New York: Moody's Investors Service).

Moody's Investors Service, 2001, "Default and Recovery Rates of Corporate Bond Issuers: 2000," Special Comment, February (New York: Moody's Investors Service).

Mulder, Christian, and Roberto Perrelli, 2001, "Foreign Currency Credit Ratings for Emerging Market Economies," IMF Working Paper N 191 (Washington D.C.: International Monetary Fund).

Obstfeld, Maurice, and Kenneth Rogoff, 1996, "Chap. 6: Imperfections in International Capital Markets," in Foundations of International Macroeconomics, (Cambridge, MA, and London: MIT Press), pp. 349-428.

Odedokun, M.O., 1995, "Analysis of probability of external debt rescheduling in subsaharan Africa," Scottish Journal of Political Economy, Vol. 42 (1), pp. 82-98.

Oral, Muhittin, Ossama Kettani, Jean-Claude Cosset, and Mohamed Daouas, 1992, "An estimation model for country risk rating," International Journal of Forecasting, Vol. 8, pp. 583-593.

Peter, Marcel, 2002, "Do Rating Agency's and Banks' Sovereign Credit Ratings Adequately reflect Sovereign Default Risk?," Unpublished manuscript (Geneva: The Graduate Institute of International Studies). 
Rivoli, Pietra, and Thomas L. Brewer, 1997, "Political Instability and Country Risk," Global Finance Journal, Vol. 8 (2), pp. 309-321.

Saini, Krishan G, and Philip S Bates, 1984, "A Survey of the Quantitative Approaches to Country Risk Analysis," Journal of Banking and Finance, Vol. 8, pp. 341356.

Saini, Krishan G., and Philip S. Bates, 1978, "Statistical techniques for determining debt-servicing capacity for developing countries: Analytical review of the literature and further empirical results," Federal Reserve Bank of New York Research Paper $N^{\circ} 7818$ (New York: Federal Reserve Bank).

Sargen, Nicholas, 1977, "Economic Indicators and Country Risk Appraisal," Federal Reserve Bank of San Francisco Economic Review, Vol. (Fall), pp. 19-35.

Solberg, Ronald L, 1988, Sovereign Rescheduling: Risk and Portfolio Management (London: Unwin Hyman).

Sommerville, R. Andrew, and Richard J. Taffler, 1995, "Banker Judgement versus Formal Forecasting Models: The Case of Country Risk Assessment," Journal of Banking and Finance, Vol. 19 (2), pp. 281-297.

Standard \& Poor's, 1997, "Behind the Ratings. Sovereign Credit Ratings: A Primer," Standard \& Poor's CreditWeek, Vol. (April 16), pp. 21-28.

Standard \& Poor's, 1999a, "1998: Corporate Defaults Rise Sharply," Standard \& Poor's Credit Week, Vol. (March 10), pp. 9-16.

Standard \& Poor's, 1999b, "Sovereign Defaults: Hiatus in 2000?," Standard \& Poor's CreditWeek, Vol. (December 22), pp. 9-21.

Standard \& Poor's, 2001a, "Ratings Performance 2000 - Default, Transition, Recovery, and Spreads," Special Report, January (New York: Standard \& Poor's).

Standard \& Poor's, 2001b, "The Rise and Fall of Sovereign Ratings: 2000," in Ratings Performance 2000 - Default, Transition, Recovery and Spread, ed. by Standard \& Poor's (New York: Standard \& Poor's), pp. 87-92.

Standard \& Poor's, 2001c, "Sovereign Defaults Decline Through Third-Quarter 2000," in Ratings Performance 2000. Default, Recovery, Transition, and Spreads, ed. by Standard \& Poor's (New York: Standard \& Poor's), pp. 93-96.

Stiglitz, Joseph, and Andrew Weiss, 1981, "Credit Rationing in Markets with Imperfect Information," American Economic Review, Vol. 73 (2), pp. 393-410.

Treasurer's Department, 1998, "Financial Organization and Operations of the IMF," Pamphlet Series No. 45 (Washington: International Monetary Fund).

World Bank, 2000, Global Development Finance - Country Tables (Washington D.C.: The World Bank). 

APPENDIX

Table 1a: Summary of Previous Studies Analysing Sovereign Defaults

\begin{tabular}{|c|c|c|c|c|c|c|c|c|}
\hline Study & & Cline (1984) & \begin{tabular}{|l} 
Citron and \\
Nickelsburg \\
(1987)
\end{tabular} & Lee (1991) & Balkan (1992) & Odedokun (1995) & $\begin{array}{l}\text { Marashaden } \\
(1997)\end{array}$ & \begin{tabular}{|l} 
Rivoli and \\
Brewer (1997)
\end{tabular} \\
\hline \multirow{5}{*}{ Dependent Variable } & 1 if rescheduling, 0 otherwise & $\begin{array}{l}1 \text { if rescheduling, } \\
0 \text { otherwise }\end{array}$ & $\begin{array}{l}1 \text { if rescheduling, } 0 \\
\text { otherwise }\end{array}$ & $\begin{array}{l}1 \text { if rescheduling, } \\
0 \text { otherwise }\end{array}$ & $\left\{\begin{array}{l}1 \text { if rescheduling, } 0 \\
\text { otherwise }\end{array}\right.$ & $\begin{array}{l}1 \text { if rescheduling, } 0 \\
\text { otherwise }\end{array}$ & $\begin{array}{l}1 \text { if rescheduling, } \\
0 \text { otherwise }\end{array}$ & $\begin{array}{l}1 \text { if rescheduling, } \\
0 \text { otherwise }\end{array}$ \\
\hline & 1 if arrears, 0 otherwise & & & & & & & \\
\hline & $\begin{array}{l}1 \text { if rescheduling or "upper-tranche" } \\
\text { IMF arrangements (a), } 0 \text { otherwise }\end{array}$ & & & & & & & \\
\hline & $\begin{array}{l}1 \text { if rescheduling or significant } \\
\text { arrears on principal or on interest, } 0 \\
\text { otherwise }\end{array}$ & & & & & & & \\
\hline & $\begin{array}{l}1 \text { if rescheduling or upper-tranche } \\
\text { IMF arrangement or significant } \\
\text { arrears on principal or interest, } 0 \\
\text { otherwise }\end{array}$ & & & & & & & \\
\hline \multirow{28}{*}{ Explanatory Variables } & Total external debt / GDP & & & pos & pos & pos & & pos \\
\hline & Total external debt / exports & & & & & pos & pos & \\
\hline & Short term debt / total debt & & & & & & & \\
\hline & Interest service (due) / exports & & & & & & pos & \\
\hline & Principal repayments (due) / exports & $\operatorname{neg}(\mathrm{p})$ & & & neg (p) & & & $\operatorname{neg}(\mathrm{p})$ \\
\hline & Debt service (due) / exports & pos & & & pos & pos & pos & pos \\
\hline & Reserves / imports & neg & neg & & neg & neg (j) & neg & neg \\
\hline & Exports / GDP & & & & & & & $f+x_{5}$ \\
\hline & Imports / GDP & & & & pos & & $(\mathrm{neg})$ & \\
\hline & Current account / GDP or exports & neg & (neg) & & (pos) & & pos & (pos) \\
\hline & Investment / GDP & & & & & neg & & \\
\hline & \begin{tabular}{|l|} 
Terms of trade change \\
\end{tabular} & & & & & neg & & \\
\hline & $\begin{array}{l}\text { Private capital inflows/GDP or debt } \\
\text { service due }\end{array}$ & & & & & $\operatorname{neg}(1)$ & & \\
\hline & GDP (GNP) per capita & (pos) & & & & (neg) & & \\
\hline & Variability of GDP per capita growth & & & (neg) & & & & \\
\hline & \begin{tabular}{|l} 
GDP growth rate \\
\end{tabular} & (neg) & (neg) & $\operatorname{neg}(q)$ & neg & neg & & \\
\hline & \begin{tabular}{|l} 
Export growth rate \\
\end{tabular} & & & & & neg & (pos) & \\
\hline & Inflation rate & & & & (pos) & pos & & \\
\hline & Misalignment of (real) exchange rate & & & & & pos (o) & & \\
\hline & Outward orientation (openness) & & & & & & & \\
\hline & Arrears / exports & & & & & & & \\
\hline & $\begin{array}{l}\text { Growth rate in industrialized } \\
\text { countries }\end{array}$ & & & neg & (pos) & & & \\
\hline & \begin{tabular}{|l|} 
Current account / GDP in \\
industrialized countries
\end{tabular} & & & & & & & \\
\hline & \begin{tabular}{|l|} 
Real interest rate on international \\
lending
\end{tabular} & & & pos & & & & \\
\hline & $\begin{array}{l}\text { Political variables tested. Found } \\
\text { significant? }\end{array}$ & & yes & & yes & & & some \\
\hline & $\begin{array}{l}\text { Aspects of repayment history tested. } \\
\text { Found significant? (g) }\end{array}$ & & & & & & & \\
\hline & $\begin{array}{l}\text { Lagged dependent variable (= state } \\
\text { dependence) tested. Found } \\
\text { significant? }\end{array}$ & & & & & & & yes \\
\hline & $\begin{array}{l}\begin{array}{l}\text { Country heterogeneity tested. Found } \\
\text { significant? }\end{array} \\
\end{array}$ & & & & & & & \\
\hline \multirow{3}{*}{ Goodness of Fit } & $\%$ correct predictions (h) & 85 & n.a. & n.a. & 94.6 & $\overline{73.3}$ & 86.8 & 85 \\
\hline & $\%$ type I errors & 9.1 & n.a. & n.a. & 7.3 & n.a. & 11 & 63 \\
\hline & $\%$ type II errors & 13 & n.a. & n.a. & 5.2 & n.a. & n.a. & 4 \\
\hline Estimation Method & & Standard logit & Standard logit & Standard logit & Standard probit & $\begin{array}{l}\text { Standard logit and } \\
\text { probit }\end{array}$ & Standard logit & Standard logit \\
\hline \begin{tabular}{|l|} 
No of countries analysed \\
\end{tabular} & & 60 & 5 & 75 & 33 & 35 (i) & 52 & 80 \\
\hline Period studied & & $1969-1982$ & 1961-1982 & $1970-1985$ & 1971-1984 & $1980-1990$ & $1980-1988$ & $1980-1990$ \\
\hline Total no of observations & & $574-670$ & 110 & 1152 & 462 & $327-348$ & 468 & 880 \\
\hline
\end{tabular}

Notes:

For a detailed discussion of table 1, see section II of the main text.

(a) See Treasurer's Department (1998, pp. 60-73).

(b) These models allow for autocorrelation in the errors.

(c) This parameter was significantly positive in the probit regression of the payments problems dummy on explanatory variables

but significantly negative in the tobit regression of arrears (\% of total debt) on explanatory variables.

(d) Debt service due / total external debt.

(e) Reserves / total external debt.

(f) Section IV D.

(g) Cumulative counts of years of IMF upper-tranche arrangements, of reschedulings or of significant arrears.

(h) in the "best" model.

(i) Sub-saharan countries only,

(j) Reserves / total external debt.

(k) Net non-debt creating capital inflows / debt service due.

(l) Gross disbursement of long-term foreign private capital plus net foreign direct investment/GNP.

(m) Foreign direct investment / GDP.

(n) Overvaluation, measured as black market exchange rate premium over official exchange rate.

(o) Rate of real depreciation.

(p) Principal repayments due / total external debt.

(q) Growth rate of per capita GDP. 
Table 1b: Summary of Previous Studies Analysing Sovereign Defaults (continued)

\begin{tabular}{|c|c|c|c|c|c|c|}
\hline Study & & $\begin{array}{l}\text { Aylward et al. } \\
\text { (1998) (f) }\end{array}$ & Hajivassiliou (1987) & Li (1992) & Callier (1985) & Detragiache et al. (2000) \\
\hline \multirow{5}{*}{ Dependent Variable } & 1 if rescheduling, 0 otherwise & & & & & \\
\hline & 1 if arrears, 0 otherwise & $\begin{array}{l}1 \text { if arrears, } 0 \\
\text { otherwise }\end{array}$ & & & & \\
\hline & $\begin{array}{l}1 \text { if rescheduling or "upper-tranche" } \\
\text { IMF arrangements (a), } 0 \text { otherwise }\end{array}$ & & \begin{tabular}{|l}
1 if rescheduling (with \\
private or public \\
creditors) or IMF upper- \\
tranche arrangement, 0 \\
otherwise
\end{tabular} & \begin{tabular}{|l}
1 if rescheduling (with \\
private or public \\
creditors) or IMF upper- \\
tranche arrangement, 0 \\
otherwise
\end{tabular} & & \\
\hline & $\begin{array}{l}1 \text { if rescheduling or significant } \\
\text { arrears on principal or on interest, } 0 \\
\text { otherwise }\end{array}$ & & & & $\begin{array}{l}1 \text { if rescheduling or } \\
\text { arrears on imports or } \\
\text { on interest, } 0 \\
\text { otherwise }\end{array}$ & $\begin{array}{l}1 \text { if rescheduling (with private } \\
\text { creditors) or arrears of principal and } \\
\text { interest on external obligations } \\
\text { towards private creditors }>5 \% \text { of } \\
\text { total long term debt service due, or, } 0 \\
\text { otherwise }\end{array}$ \\
\hline & $\begin{array}{l}\text { if rescheduling or upper-tranche } \\
\text { IMF arrangement or significant } \\
\text { arrears on principal or interest, } 0 \\
\text { otherwise }\end{array}$ & & & & & \\
\hline \multirow{28}{*}{ Explanatory Variables } & Total external debt / GDP & pos & & pos & pos & pos \\
\hline & Total external debt / exports & & pos & & & \\
\hline & Short term debt / total debt & & & & & pos \\
\hline & Interest service (due) / exports & & (pos) & pos & & \\
\hline & Principal repayments (due) / exports & & (pos) & & & \\
\hline & Debt service (due) / exports & (pos) & pos & & & pos (d) \\
\hline & Reserves / imports & neg & (pos) & neg & & neg (e) \\
\hline & Exports / GDP & neg & (neg) & & & \\
\hline & Imports / GDP & (pos) & pos & & & \\
\hline & Current account / GDP or exports & & & & neg & neg \\
\hline & Investment / GDP & & & neg & neg & \\
\hline & Terms of trade change & & & & & \\
\hline & $\begin{array}{l}\text { Private capital inflows/GDP or debt } \\
\text { service due }\end{array}$ & & & & & (pos) (m) \\
\hline & GDP (GNP) per capita & (neg) & neg & & & \\
\hline & Variability of GDP per capita growth & & & & & \\
\hline & GDP growth rate & (neg) & (pos) & neg & & (neg) \\
\hline & Export growth rate & & & & & \\
\hline & Inflation rate & (pos) & & & & \\
\hline & Misalignment of (real) exchange rate & & & & & \\
\hline & Outward orientation (openness) & & & & neg & \\
\hline & Arrears / exports & & & & & \\
\hline & $\begin{array}{l}\text { Growth rate in industrialized } \\
\text { countries }\end{array}$ & & & neg & & \\
\hline & $\begin{array}{l}\text { Current account / GDP in } \\
\text { industrialized countries }\end{array}$ & & & neg & & \\
\hline & $\begin{array}{l}\text { Real interest rate on international } \\
\text { lending }\end{array}$ & & & & & (pos) \\
\hline & $\begin{array}{l}\text { Political variables tested. Found } \\
\text { significant? }\end{array}$ & & & some & & \\
\hline & \begin{tabular}{|l|} 
Aspects of repayment history tested. \\
Found significant? (g)
\end{tabular} & & sometimes & yes & & \\
\hline & $\begin{array}{l}\text { Lagged dependent variable (= state } \\
\text { dependence) tested. Found } \\
\text { significant? }\end{array}$ & yes & & & & \\
\hline & $\begin{array}{l}\text { Country heterogeneity tested. Found } \\
\text { significant? }\end{array}$ & & yes & partially & & \\
\hline \multirow{3}{*}{ Goodness of Fit } & \% correct predictions (h) & 94.78 & n.a. & 87.71 & 88.7 & n.a. \\
\hline & $\%$ type I errors & 8 & n.a. & 5.67 & 8.7 & n.a. \\
\hline & \% type II errors & 3 & n.a. & 25.25 & 18.8 & n.a. \\
\hline \multicolumn{2}{|l|}{ Estimation Method } & $\begin{array}{l}\text { Standard logit (with } \\
\text { and without lagged } \\
\text { dependent }\end{array}$ & $\begin{array}{l}\text { Standard probit; random } \\
\text { effects probit; tobit }\end{array}$ & Fixed effects logit & Standard logit & $\begin{array}{l}\text { Standard probit; random effects } \\
\text { probit; fixed effects logit }\end{array}$ \\
\hline \multicolumn{2}{|l|}{ No of countries analysed } & 138 & 79 & 19 & 62 & 78 \\
\hline Period studied & & $1976-1993$ & $1971-1982$ & $1971-1986$ & $1971-1982$ & $1971-1998$ \\
\hline \multicolumn{2}{|l|}{ Total no of observations } & 1398 & 823 & 293 & 62 & $612-936$ \\
\hline
\end{tabular}

Notes:

For a detailed discussion of table 1 , see section II of the main text

(a) See Treasurer's Department (1998, pp. 60-73).

(b) These models allow for autocorrelation in the errors.

(c) This parameter was significantly positive in the probit regression of the payments problems dummy on explanatory variables

but significantly negative in the tobit regression of arrears (\% of total debt) on explanatory variables.

(d) Debt service due / total external debt.

(e) Reserves / total external debt.

(f) Section IV D.

(g) Cumulative counts of years of IMF upper-tranche arrangements, of reschedulings or of significant arrears.

(h) in the "best" model.

(i) Sub-saharan countries only.

(j) Reserves/Total external debt.

(k) Net non-debt creating capital inflows/debt service due.

(1) Gross disbursement of long-term foreign private capital plus net foreign direct investment/GNP

(m) Foreign direct investment/GDP.

(n) Overvaluation, measured as black market exchange rate premium over official exchange rate.

(o) Rate of real depreciation.

(p) Principal repayments due / total external debt.

(q) Growth rate of per capita GDP. 
Table 1c: Summary of Previous Studies Analysing Sovereign Defaults (continued)

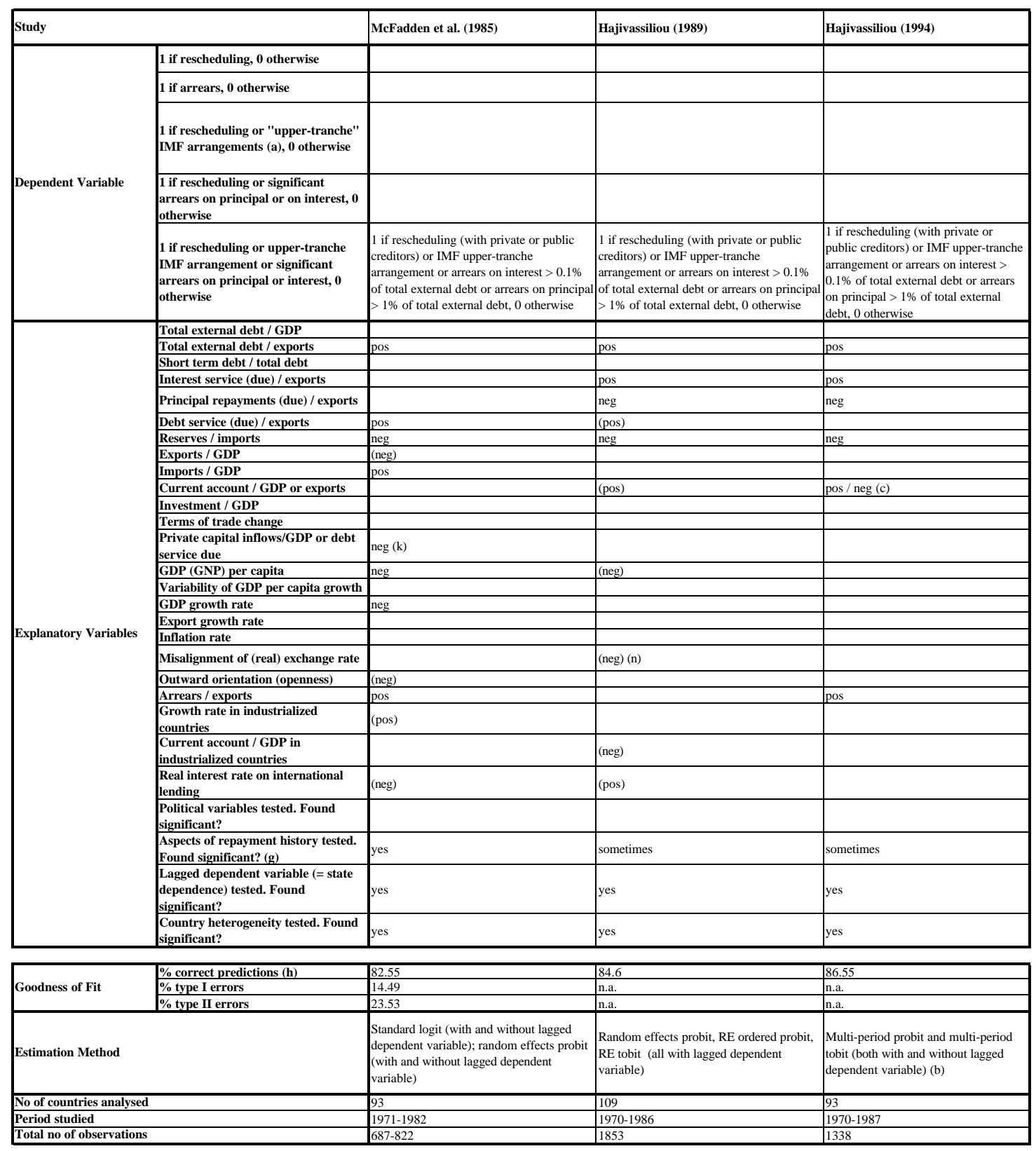

\section{Notes:}

For a detailed discussion of table 1, see section II of the main text.

(a) See Treasurer's Department (1998, pp. 60-73).

(b) These models allow for autocorrelation in the errors

(c) This parameter was significantly positive in the probit regression of the payments problems dummy on explanatory variables

but significantly negative in the tobit regression of arrears (\% of total debt) on explanatory variables.

(d) Debt service due / total external debt.

(e) Reserves / total external debt.

(f) Section IV D.

(g) Cumulative counts of years of IMF upper-tranche arrangements, of reschedulings or of significant arrears.

(h) in the "best" model.

(i) Sub-saharan countries only.

(j) Reserves/Total external debt.

(k) Net non-debt creating capital inflows/debt service due.

(1) Gross disbursement of long-term foreign private capital plus net foreign direct investment/GNP

(m) Foreign direct investment/GDP.

(n) Overvaluation, measured as black market exchange rate premium over official exchange rate.

(o) Rate of real depreciation.

(p) Principal repayments due / total external debt.

(q) Growth rate of per capita GDP. 
Table 2: The Sample - Initial 150 Countries and 78 Emerging Markets Eventually Analyzed, 1984-1997

\begin{tabular}{|c|c|c|c|}
\hline ALBANIA & & GHANA & PAPUA NEW GUINEA \\
\hline ALGERIA & & GRENADA & PARAGUAY \\
\hline ANGOLA & & GUATEMALA & PERU \\
\hline ARGENTINA & & GUINEA & PHILIPPINES \\
\hline ARMENIA & & GUINEA-BISSAU & POLAND \\
\hline \multirow[t]{2}{*}{ AZERBAIJAN } & & GUYANA & QATAR \\
\hline & BAHRAIN & HAITI & ROMANIA \\
\hline BANGLADESH & & HONDURAS & RUSSIAN FEDERATION \\
\hline BARBADOS & & HONG KONG & RWANDA \\
\hline BELARUS & & HUNGARY & SAMOA \\
\hline BELIZE & & INDIA & SAO TOME AND PRINCIPE \\
\hline BENIN & & INDONESIA & SAUDI ARABIA \\
\hline BHUTAN & & IRAN, ISLAMIC REP. & SENEGAL \\
\hline BOLIVIA & & ISRAEL & SEYCHELLES \\
\hline BOSNIA AND HERZEGOVINA & & JAMAICA & SIERRA LEONE \\
\hline BOTSWANA & & JORDAN & SINGAPORE \\
\hline BRAZIL & & KAZAKHSTAN & SLOVAKIA \\
\hline BULGARIA & & KENYA & SLOVENIA \\
\hline BURKINA FASO & & KOREA, REP. OF & SOLOMON ISLANDS \\
\hline BURUNDI & & KYRGYZ REPUBLIC & SOMALIA \\
\hline CAMBODIA & & LAO PDR & SOUTH AFRICA \\
\hline CAMEROON & & LATVIA & SRI LANKA \\
\hline CAPE VERDE & & LEBANON & ST. KITTS AND NEVIS \\
\hline CENTRAL AFRICAN REPUBLIC & & LESOTHO & ST. LUCIA \\
\hline CHAD & & LIBERIA & ST. VINCENT AND THE GRENADINES \\
\hline CHILE & & LITHUANIA & SUDAN \\
\hline CHINA & & LIBYA & SWAZILAND \\
\hline COLOMBIA & & MACEDONIA, FYR & SYRIAN ARAB REPUBLIC \\
\hline COMOROS & & MADAGASCAR & TAIWAN \\
\hline CONGO, DEM. REP. & & MALAWI & TAJIKISTAN \\
\hline CONGO, REP. & & MALAYSIA & TANZANIA \\
\hline COSTA RICA & & MALDIVES & THAILAND \\
\hline COTE D'IVOIRE & & MALI & TOGO \\
\hline CROATIA & & MALTA & TONGA \\
\hline & CYPRUS & MAURITANIA & TRINIDAD AND TOBAGO \\
\hline CZECH REPUBLIC & & MAURITIUS & TUNISIA \\
\hline DJIBOUTI & & MEXICO & TURKEY \\
\hline DOMINICA & & MOLDOVA & TURKMENISTAN \\
\hline DOMINICAN REPUBLIC & & MONGOLIA & UGANDA \\
\hline ECUADOR & & MOROCCO & UKRAINE \\
\hline EGYPT & & MOZAMBIQUE & UNITED ARAB EMIRATES \\
\hline EL SALVADOR & & MYANMAR & URUGUAY \\
\hline EQUATORIAL GUINEA & & NAMIBIA & UZBEKISTAN \\
\hline ERITREA & & NEPAL & VANUATU \\
\hline ESTONIA & & NICARAGUA & VENEZUELA \\
\hline ETHIOPIA & & NIGER & VIETNAM \\
\hline FIJI & & NIGERIA & YEMEN \\
\hline GABON & & OMAN & YUGOSLAVIA \\
\hline GAMBIA, THE & & PAKISTAN & ZAMBIA \\
\hline GEORGIA & & PANAMA & ZIMBABWE \\
\hline
\end{tabular}

Notes:

Countries aligned right and in italics: 12 countries with external debt data from EIU CountryData (Economist Intelligence Unit). Data on 138 other countries are from Global Development Finance 1999 on CD-Rom.

$=78$ emerging markets eventually analyzed. 
Figure 1: Number of Sovereign Defaults per Year, 1981-1997
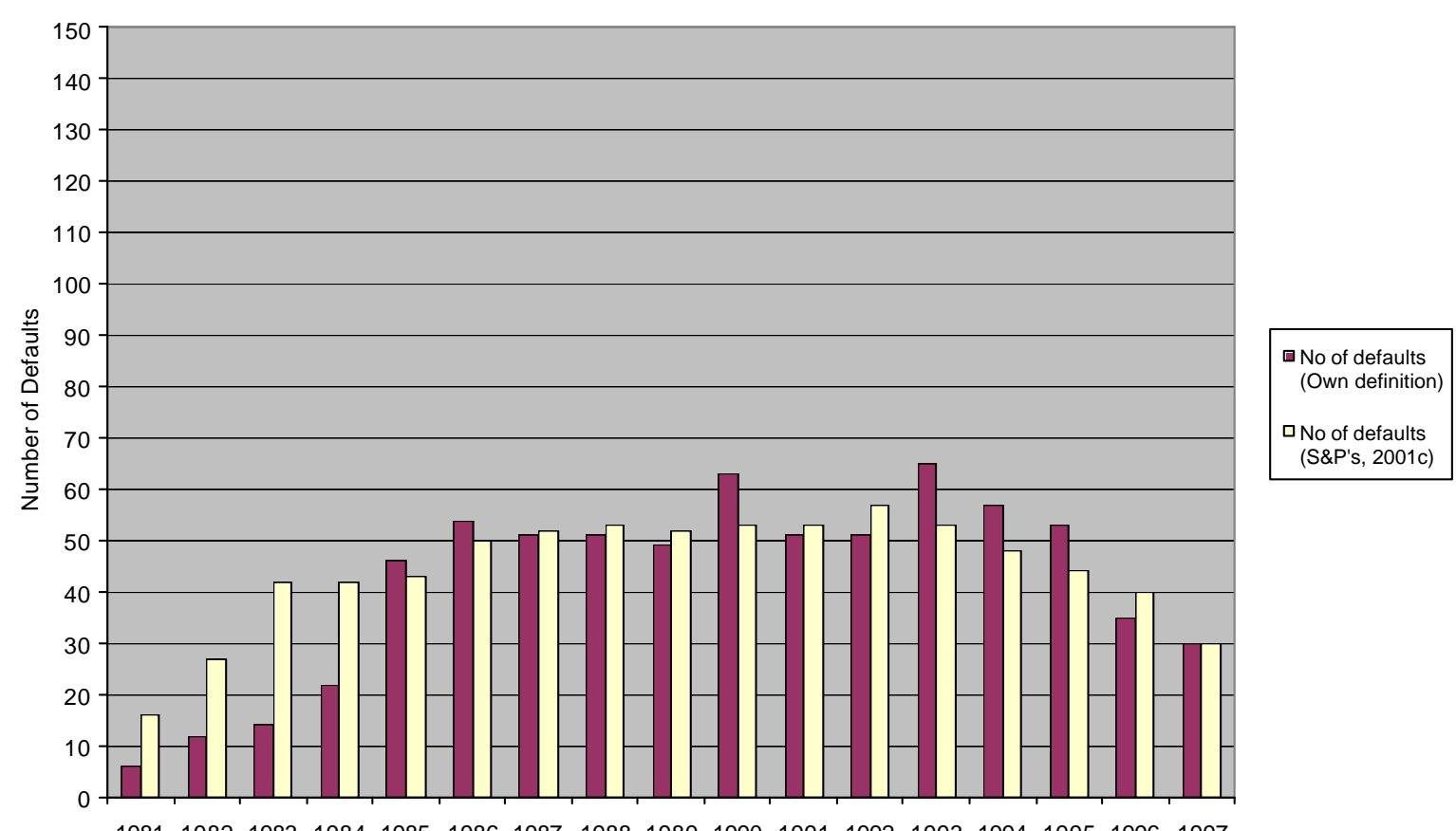

Notes: Default threshold ("own definition"): increase in arrears/external debt $>2 \%$ and/or debt rescheduled/external debt $>2.5 \%$; Number of countries analyzed:150. Source for number of defaults by S\&P, see Standard \& Poor's (2001c), p.94.

Table 3: Descriptive Statistics for the 11 Explanatory Variables, 1984-1997

\begin{tabular}{|c|c|c|c|c|c|c|c|c|c|c|c|}
\hline & $\begin{array}{l}\text { CA- } \\
\text { GDPN }^{(a)}\end{array}$ & $\begin{array}{l}\text { LDEB- } \\
\text { ST2 }\end{array}$ & $\begin{array}{l}\text { LARR- } \\
\text { EDT }\end{array}$ & M2IR & $\begin{array}{l}\text { CR- } \\
\text { PRIV } \\
\end{array}$ & CPIINF & $\begin{array}{l}\text { DRER2- } \\
\text { HP }\end{array}$ & $\begin{array}{l}\text { VGNP- } \\
\text { CAPG2 } \\
\end{array}$ & $\begin{array}{l}\text { POL- } \\
\text { RISK6 }\end{array}$ & $\begin{array}{l}\text { LIB6M- } \\
\text { RE1 }\end{array}$ & $\begin{array}{l}\text { L2DOR- } \\
\text { EDT3ME }\end{array}$ \\
\hline Mean & -0.037 & 0.020 & 6.348 & 14.239 & 31.589 & 94.688 & -0.173 & 4.862 & 24.288 & 3.572 & 0.564 \\
\hline Median & -0.034 & -0.035 & 0.523 & 4.881 & 26.301 & 13.145 & -1.094 & 4.225 & 24.750 & 3.274 & 1.000 \\
\hline Maximum & 0.429 & 4.621 & 79.289 & 1021.9 & 161.0 & 11749.6 & 378.961 & 25.600 & 39.000 & 7.728 & 1.000 \\
\hline Minimum & -0.452 & -4.344 & 0 & 0.188 & 1.542 & -11.686 & -96.117 & 0.194 & 4.333 & 0.803 & 0.000 \\
\hline Std. Dev. & 0.068 & 1.798 & 12.453 & 47.910 & 23.947 & 660.719 & 22.981 & 3.125 & 5.810 & 1.875 & 0.496 \\
\hline Skewness & -0.53 & 0.09 & 2.850 & 13.01 & 1.64 & 12.91 & 5.83 & 2.15 & -0.45 & 0.772 & -0.26 \\
\hline Kurtosis & 11.33 & 2.23 & 11.872 & 228.13 & 6.76 & 190.52 & 93.65 & 11.24 & 3.31 & 3.452 & 1.07 \\
\hline $\begin{array}{l}\text { Jarque- } \\
\text { Bera }\end{array}$ & 3014 & 27 & 5301 & 2287645 & 1077 & 1472086 & 391531 & 3833 & 38 & 1.511 & 160 \\
\hline Probability & 0.000 & 0.000 & 0 & 0.000 & 0.000 & 0.000 & 0.000 & 0.000 & 0.000 & 0.470 & 0.000 \\
\hline $\begin{array}{l}\text { Obser- } \\
\text { vations }\end{array}$ & 807 & 826 & 901 & 837 & 819 & 777 & 886 & 849 & 892 & 14 & 872 \\
\hline
\end{tabular}

Notes: ${ }^{(a)}$ For an explanation of the explanatory variables, see section III C. 
Table 4: Estimation Results

Dependent Variable: Sovereign default (DOREDT3ME)

\begin{tabular}{|c|c|c|c|c|c|c|c|c|c|}
\hline \multirow{3}{*}{ Explanatory Variables } & \multicolumn{3}{|c|}{ Model 1} & \multicolumn{3}{|c|}{ Model 2} & \multicolumn{3}{|c|}{ Model 3} \\
\hline & \multicolumn{2}{|l|}{ (1) } & (2) & \multicolumn{2}{|l|}{ (3) } & (4) & \multicolumn{2}{|l|}{ (5) } & (6) \\
\hline & \multicolumn{2}{|c|}{$\begin{array}{l}\text { Coefficient } \\
\text { (t-Stat) }\end{array}$} & $\begin{array}{l}\text { Marginal } \\
\text { effects } \\
\left(? \mathrm{P} / \text { ?x }_{\mathrm{i}}\right)^{(\mathrm{a})} \\
\end{array}$ & \multicolumn{2}{|c|}{$\begin{array}{l}\text { Coefficient } \\
\text { (t-Stat) }\end{array}$} & $\begin{array}{l}\text { Marginal } \\
\text { effects } \\
\left(? \mathrm{P} / \mathrm{Px}_{\mathrm{i}}\right)^{(\mathrm{a})}\end{array}$ & \multicolumn{2}{|c|}{$\begin{array}{l}\text { Coefficient } \\
\text { (t-Stat) }\end{array}$} & $\begin{array}{l}\text { Marginal } \\
\text { effects } \\
\left(? \mathrm{P} / \mathbf{P x}_{\mathrm{i}}\right)^{(\mathrm{a})} \\
\end{array}$ \\
\hline CONSTANT & $\begin{array}{r}-4.1127 \\
(-5.47)\end{array}$ & $\star * \star$ & n.a. & $\begin{array}{r}-2.8342 \\
(-4.07)\end{array}$ & *** & n.a. & $\begin{array}{r}-3.7256 \\
(-5.22)\end{array}$ & $\star \star \star$ & n.a. \\
\hline CAGDPN & $\begin{array}{r}-0.0767 \\
(-2.8)\end{array}$ & $\star \star \star$ & -0.01602 & $\begin{array}{r}-0.0636 \\
(-2.48)\end{array}$ & ** & -0.01196 & $\begin{array}{r}-0.0685 \\
(-2.68)\end{array}$ & $\star \star \star *$ & -0.01357 \\
\hline LDEBST2 & $\begin{array}{r}0.1900 \\
(2.12)\end{array}$ & ** & 0.03650 & $\begin{array}{r}0.2274 \\
(3.26)\end{array}$ & $* * *$ & 0.03864 & $\begin{array}{r}0.2024 \\
(2.24)\end{array}$ & $\star *$ & 0.03803 \\
\hline $\begin{array}{l}\operatorname{LDGNP}^{(b)} \\
\operatorname{LDEXP}^{(b)}\end{array}$ & & & $\begin{array}{l}0.00042 \\
0.00010\end{array}$ & & & $\begin{array}{l}0.00044 \\
0.00011\end{array}$ & & & $\begin{array}{l}0.00043 \\
0.00011\end{array}$ \\
\hline LARREDT & $\begin{array}{r}0.0746 \\
(2.5)\end{array}$ & ** & 0.01536 & $\begin{array}{r}0.2660 \\
(4.39)\end{array}$ & $* * *$ & 0.04701 & $\begin{array}{r}0.0684 \\
(2.51)\end{array}$ & ** & 0.01283 \\
\hline M2IR & $\begin{array}{r}0.0627 \\
(2.96)\end{array}$ & $\star \star \star$ & 0.01271 & $\begin{array}{r}0.0514 \\
(5.5)\end{array}$ & $\star \star \star *$ & 0.00870 & $\begin{array}{r}0.0667 \\
(3.11)\end{array}$ & $\star \star \star *$ & 0.01221 \\
\hline CRPRIV & $\begin{array}{r}0.0198 \\
(2.56)\end{array}$ & ** & 0.00389 & $\begin{array}{r}0.0023 \\
(0.49)\end{array}$ & & 0.00040 & & & \\
\hline CPIINF2 & $\begin{array}{r}0.0172 \\
(2.95)\end{array}$ & $\star \star \star$ & 0.00351 & $\begin{array}{r}0.0194 \\
(4.07)\end{array}$ & $\star \star \star *$ & 0.00344 & $\begin{array}{r}0.0119 \\
(2.58)\end{array}$ & $\star \star \star$ & 0.00227 \\
\hline$\left(\right.$ DRER2HP)^2 ${ }^{\text {(c) }}$ & $\begin{array}{r}0.0011 \\
(2.02)\end{array}$ & ** & 0.00007 & $\begin{array}{r}0.0006 \\
(2.3)\end{array}$ & ** & 0.00004 & $\begin{array}{r}0.0008 \\
(1.85)\end{array}$ & * & 0.00005 \\
\hline VGNPCAPG2 & $\begin{array}{r}0.1371 \\
(2.39)\end{array}$ & $\star \star$ & 0.02667 & $\begin{array}{r}0.3269 \\
(7.19)\end{array}$ & $\star \star \star$ & 0.05601 & $\begin{array}{r}0.1349 \\
(2.47)\end{array}$ & $\star \star$ & 0.02471 \\
\hline POLRISK6 & $\begin{array}{r}-0.1244 \\
(-3.94)\end{array}$ & $\star \star \star *$ & -0.02532 & $\begin{array}{r}-0.0673 \\
(-3.06)\end{array}$ & $\star \star \star *$ & -0.01258 & $\begin{array}{r}-0.0904 \\
(-3.55)\end{array}$ & $\star \star \star *$ & -0.01752 \\
\hline LIB6MRE1 & $\begin{array}{r}0.4471 \\
(5.59)\end{array}$ & $\star \star \star *$ & 0.09099 & $\begin{array}{r}0.2306 \\
(4.08)\end{array}$ & $\star \star \star *$ & 0.04085 & $\begin{array}{r}0.4123 \\
(5.45)\end{array}$ & $\star \star \star$ & 0.07901 \\
\hline L3DOREDT3ME $^{\text {(d) }}$ & $\begin{array}{l}4.5237 \\
(10.38)\end{array}$ & $\star \star \star *$ & 0.68542 & & & & $\begin{array}{l}4.1661 \\
(10.53)\end{array}$ & $\star \star *$ & 0.69870 \\
\hline McFadden R-squared & & 0.65 & & & 0.44 & & & 0.64 & \\
\hline S.E. of regression & & 0.26 & & & 0.34 & & & 0.26 & \\
\hline Akaike & & 0.50 & & & 0.77 & & & 0.51 & \\
\hline LR statistic & & 628.2 & & & 433.4 & & & 619.8 & \\
\hline P-value of LR stat & & 0.000 & & & 0.000 & & & 0.000 & \\
\hline Observations & & 717 & & & 735 & & & 724 & \\
\hline Percent correct classifications & & 92.05 & & & 84.63 & & & 91.71 & \\
\hline Percent type I errors & & 5.28 & & & 14.86 & & & 5.20 & \\
\hline Percent type II errors & & 12.10 & & & 16.20 & & & 13.12 & \\
\hline Obs with Dep $=0$ & & 281 & & & 284 & & & 282 & \\
\hline Obs with $\mathrm{Dep}=1$ & & 436 & & & 451 & & & 442 & \\
\hline Mean dep. var. & & 0.61 & & & 0.61 & & & 0.61 & \\
\hline
\end{tabular}

Notes:

Estimation Method: Maximum Likelihood - Binary Logit. t-statistics (in parentheses) are derived using robust QML (Huber/White) standard errors. Significance at $10 \%, 5 \%$, and $1 \%$ are denoted by ${ }^{*},{ }^{* \star}$, and ${ }^{* * \star}$, respectively.

(a) Marginal effects are calculated at the sample means of the explanatory variables, except for the dummy I3doredt3me (default over the past three years) where 0 was taken instead of the sample mean, which is 0.56 .

(b) Lagged debt-GNP and debt-exports ratios: in order to gain a better impression of the economic significance of the debt stock indicator LDEBST2, the marginal effects have been calculated for the two components individually.

(c) The marginal effect is evaluated at the absolute value of DRER2HP (instead of at DRER2HP^2).

(d) As suggested by Greene (2000, p. 817), this marginal effect is calculated as the default probability when I3doredt3me $=1$ minus the default probability when 13 doredt $3 \mathrm{me}=0$, the other explanatory variables being equal to their sample means. 
Table 5: 3-Year-Ahead Default Probabilities (in \%) of Model 3

\begin{tabular}{|c|c|c|c|c|c|c|c|c|c|c|c|}
\hline & \multicolumn{8}{|c|}{ In-Sample Default Probabilities (DPs) } & \multicolumn{3}{|c|}{ Out-of-Sample DPs } \\
\hline Country & 1990 & 1991 & 1992 & 1993 & 1994 & 1995 & 1996 & 1997 & 1998 & 1999 & 2000 \\
\hline ALGERIA & 20.39 & 10.81 & 3.64 & 2.64 & 4.35 & 85.85 & 64.59 & 69.26 & 81.52 & 71.77 & 53.49 \\
\hline ANGOLA & & & & & & 100.00 & 100.00 & 99.99 & 99.99 & 99.99 & 100.00 \\
\hline ARGENTINA & 100.00 & 98.96 & 94.72 & 95.80 & 90.42 & 94.11 & 91.76 & 23.47 & 16.64 & 9.13 & 18.15 \\
\hline AZERBAIJAN & & & & & & & & & 99.65 & 96.71 & 91.49 \\
\hline BAHRAIN & 5.53 & 8.02 & 3.56 & 1.37 & 1.96 & 2.05 & 2.50 & 5.30 & 9.21 & 2.32 & 1.82 \\
\hline BANGLADESH & 16.90 & 6.37 & 1.68 & 0.88 & 1.43 & 3.76 & 3.94 & 4.46 & 2.92 & 2.01 & 5.38 \\
\hline BOLIVIA & 88.98 & 84.32 & 67.52 & 63.79 & 55.19 & 71.56 & 72.71 & 76.00 & 66.24 & 50.49 & 71.96 \\
\hline BOTSWANA & 1.96 & 0.64 & 0.34 & 0.38 & 0.93 & 1.48 & 0.93 & 0.86 & 0.96 & 0.36 & 1.02 \\
\hline BRAZIL & 100.00 & 99.81 & 100.00 & 100.00 & 100.00 & 86.85 & 81.75 & 80.08 & 4.07 & 3.27 & 7.21 \\
\hline BULGARIA & & & 94.19 & 99.70 & 99.71 & 90.57 & 86.88 & 99.97 & 73.64 & 56.95 & 85.58 \\
\hline CAMEROON & 88.40 & 83.61 & 80.20 & 65.07 & 91.47 & 83.62 & 90.15 & 92.80 & 82.33 & 75.99 & 86.74 \\
\hline CHILE & 63.23 & 45.28 & 26.73 & 28.55 & 1.05 & 1.70 & 1.71 & 2.27 & 1.66 & 0.94 & 2.48 \\
\hline CHINA & 5.85 & 2.91 & 2.05 & 4.21 & 4.05 & 4.08 & 3.22 & 3.48 & 3.48 & 2.58 & 6.13 \\
\hline COLOMBIA & 71.91 & 47.43 & 0.48 & 0.82 & 1.52 & 2.98 & 4.17 & 11.42 & 8.60 & 3.65 & 8.48 \\
\hline COSTA RICA & & & 30.27 & 26.56 & 34.57 & 1.82 & 1.97 & 2.50 & 1.45 & 0.75 & 2.37 \\
\hline COTE D'IVOIRE & 100.00 & 99.99 & 100.00 & 100.00 & 95.06 & 93.42 & 92.43 & 92.64 & 71.13 & 53.66 & 94.99 \\
\hline CROATIA & & & & & & & & & 88.82 & 75.73 & 7.62 \\
\hline CYPRUS & 3.00 & 3.06 & 1.19 & 0.50 & 1.02 & 2.39 & 2.44 & 3.06 & 2.58 & 1.01 & 2.95 \\
\hline CZECH REPUBLIC & & & & & & & 3.10 & 3.46 & 1.57 & 0.58 & 2.71 \\
\hline DOMINICAN REPUBLIC & 98.64 & 95.99 & 83.62 & 79.50 & 91.63 & 86.65 & 88.02 & 88.97 & 75.92 & 62.66 & 82.80 \\
\hline ECUADOR & 94.50 & 94.79 & 90.57 & 92.58 & 95.37 & 97.26 & 67.62 & 83.84 & 85.55 & 68.87 & 95.70 \\
\hline EGYPT & 97.75 & 86.75 & 37.95 & 28.35 & 34.31 & 1.66 & 2.07 & 3.36 & 2.51 & 1.20 & 2.48 \\
\hline EL SALVADOR & 11.52 & 83.80 & 59.67 & 46.65 & 48.48 & 58.83 & 57.36 & 2.36 & 1.32 & 0.82 & 2.38 \\
\hline ESTONIA & & & & & & & & & 7.98 & 1.49 & 4.98 \\
\hline GABON & 90.88 & 84.16 & 84.25 & 82.57 & 94.68 & 74.68 & 48.51 & 74.25 & 88.30 & 64.31 & 68.29 \\
\hline GHANA & 6.09 & 3.14 & 1.28 & 1.69 & 4.61 & 4.52 & 5.65 & 11.42 & 8.33 & 7.70 & 10.53 \\
\hline GUATEMALA & 97.56 & 91.82 & 82.04 & 77.78 & 76.15 & 83.91 & 80.36 & 86.71 & 7.30 & 4.00 & 9.27 \\
\hline HONDURAS & 98.51 & 92.59 & 73.68 & 77.34 & 88.32 & 86.24 & 88.75 & 9.62 & 77.93 & 80.65 & 86.82 \\
\hline HONG KONG & & & & & & & 1.08 & 1.96 & 2.12 & 1.06 & 3.28 \\
\hline HUNGARY & 5.00 & 3.08 & 1.18 & 1.90 & 2.43 & 3.03 & 2.47 & 3.09 & 1.42 & 0.68 & 2.41 \\
\hline INDIA & 20.64 & 11.50 & 2.91 & 1.75 & 1.77 & 2.58 & 2.93 & 3.95 & 2.90 & 1.57 & 4.26 \\
\hline INDONESIA & 5.94 & 2.44 & 1.02 & 1.04 & 2.13 & 5.60 & 5.84 & 6.08 & 95.02 & 10.92 & 92.22 \\
\hline ISRAEL & 8.21 & 3.90 & 0.71 & 0.73 & 1.33 & 2.75 & 2.99 & 3.45 & 1.72 & 1.22 & 3.10 \\
\hline JAMAICA & 93.78 & 88.57 & 64.44 & 54.13 & 61.72 & 68.85 & 69.52 & 81.83 & 68.38 & 1.78 & 4.14 \\
\hline JORDAN & 97.10 & 97.12 & 95.24 & 88.75 & 82.38 & 83.34 & 75.20 & 78.39 & 67.89 & 31.47 & 65.07 \\
\hline KAZAKHSTAN & & & & & & & & & 7.38 & 1.87 & 80.21 \\
\hline KENYA & 12.05 & 13.03 & 18.26 & 69.73 & 71.25 & 77.39 & 67.97 & 8.21 & 7.35 & 66.79 & 87.51 \\
\hline KOREA, REP. OF & 3.39 & 2.16 & 0.51 & 0.44 & 0.85 & 1.35 & 1.49 & 1.41 & 1.47 & 0.69 & 1.96 \\
\hline LATVIA & & & & & & & & & 21.76 & 3.80 & 10.12 \\
\hline LEBANON & & 99.52 & 99.71 & 98.35 & 37.32 & 38.01 & 37.24 & 33.18 & 9.47 & 3.86 & 8.94 \\
\hline LIBYA & & & & & & & 97.52 & 98.68 & 99.31 & 97.10 & 97.25 \\
\hline LITHUANIA & & & & & & & & & 14.36 & 5.47 & 6.57 \\
\hline MALAWI & 79.37 & 84.40 & 7.58 & 5.78 & 20.21 & 23.92 & 21.75 & 25.75 & 8.14 & 7.45 & 24.92 \\
\hline MALAYSIA & 2.67 & 2.10 & 0.57 & 0.47 & 0.85 & 2.09 & 1.73 & 1.99 & 1.06 & 0.50 & 2.24 \\
\hline MEXICO & 68.47 & 59.75 & 45.22 & 35.61 & 2.08 & 5.72 & 4.42 & 4.49 & 3.17 & 1.94 & 4.17 \\
\hline MOLDOVA & & & & & & & & & 97.99 & 93.79 & 98.44 \\
\hline MOROCCO & 84.11 & 78.53 & 51.95 & 43.67 & 58.59 & 81.12 & 6.19 & 8.15 & 4.97 & 2.43 & 7.89 \\
\hline MYANMAR & 99.01 & 99.00 & 97.25 & 96.92 & 97.44 & 98.90 & 98.41 & 99.48 & 75.24 & 98.31 & 99.49 \\
\hline NAMIBIA & & & & & & 1.48 & 1.46 & 2.12 & 0.90 & 0.68 & 1.53 \\
\hline NICARAGUA & & 100.00 & 99.95 & 99.92 & 99.95 & 99.98 & 99.94 & 99.72 & 99.21 & 99.58 & 99.67 \\
\hline NIGERIA & 59.70 & 77.92 & 83.89 & 87.83 & 99.11 & 99.63 & 95.36 & 98.82 & 99.54 & 98.71 & 98.97 \\
\hline OMAN & & 1.97 & 0.75 & 1.09 & 1.40 & 2.74 & 1.74 & 2.24 & 7.07 & 0.80 & 0.53 \\
\hline PAKISTAN & 23.29 & 13.22 & 4.64 & 4.58 & 3.89 & 7.64 & 13.12 & 8.58 & 8.19 & 75.11 & 93.32 \\
\hline PANAMA & 98.99 & 99.48 & 99.06 & 98.39 & 99.17 & 99.11 & 99.38 & 80.97 & 4.68 & 2.71 & 4.80 \\
\hline PAPUA NEW GUINEA & 5.54 & 7.84 & 1.89 & 1.38 & 2.73 & 2.23 & 3.48 & 8.30 & 6.19 & 3.65 & 93.72 \\
\hline PARAGUAY & 89.92 & 84.10 & 64.33 & 36.32 & 1.89 & 2.24 & 2.80 & 3.61 & 2.72 & 1.95 & 8.32 \\
\hline
\end{tabular}




\begin{tabular}{|c|c|c|c|c|c|c|c|c|c|c|c|}
\hline & \multicolumn{8}{|c|}{ In-Sample Default Probabilities (DPs) } & \multicolumn{3}{|c|}{ Out-of-Sample DPs } \\
\hline Country & 1990 & 1991 & 1992 & 1993 & 1994 & 1995 & 1996 & 1997 & 1998 & 1999 & 2000 \\
\hline PERU & 100.00 & 100.00 & 99.66 & 98.74 & 99.06 & 99.07 & 97.81 & 91.48 & 84.83 & 68.42 & 85.62 \\
\hline PHILIPPINES & 95.18 & 86.15 & 51.92 & 50.04 & 59.42 & 67.15 & 4.43 & 3.84 & 1.41 & 0.37 & 1.02 \\
\hline POLAND & 100.00 & 97.20 & 85.63 & 63.94 & 53.19 & 48.26 & 60.86 & 61.19 & 1.09 & 0.65 & 1.95 \\
\hline QATAR & 10.19 & 9.25 & 2.70 & 2.94 & 9.69 & 17.66 & 10.88 & 25.15 & 8.49 & 1.39 & 1.40 \\
\hline ROMANIA & 12.57 & 33.90 & 83.79 & 17.65 & 6.51 & 5.22 & 6.84 & 23.93 & 8.41 & 2.39 & 7.78 \\
\hline RUSSIAN FEDERATION & & & & 100.00 & 99.17 & 99.75 & 99.69 & 99.80 & 97.14 & 83.79 & 81.60 \\
\hline SAUDI ARABIA & 5.58 & 11.83 & 2.07 & 1.84 & 3.15 & 4.23 & 2.47 & 3.79 & 5.23 & 1.43 & 1.60 \\
\hline SENEGAL & 80.92 & 67.01 & 50.50 & 54.36 & 83.58 & 77.94 & 67.47 & 74.37 & 65.92 & 58.52 & 77.41 \\
\hline SINGAPORE & 0.83 & 0.42 & 0.15 & 0.18 & 0.16 & 0.26 & 0.22 & 0.24 & 0.11 & 0.07 & 0.21 \\
\hline SLOVAKIA & & & & & & & 5.67 & 7.46 & 3.79 & 1.01 & 2.25 \\
\hline SLOVENIA & & & & & & & & & 1.35 & 0.64 & 1.92 \\
\hline SOUTH AFRICA & & & & & & & & 3.93 & 2.75 & 1.33 & 3.56 \\
\hline SRI LANKA & 10.17 & 4.44 & 1.32 & 1.03 & 1.77 & 2.53 & 3.90 & 79.03 & 65.74 & 54.61 & 8.68 \\
\hline SUDAN & & & & 99.98 & 99.98 & 99.99 & 99.99 & 99.99 & 99.98 & 99.94 & 99.97 \\
\hline SYRIAN ARAB REPUBLIC & 10.05 & 92.50 & 86.98 & 84.45 & 94.70 & 95.43 & 95.72 & 98.21 & 98.58 & 97.64 & 98.90 \\
\hline TAIWAN & 1.22 & 0.95 & 0.38 & 0.32 & 0.49 & 0.89 & 0.70 & 0.94 & 0.75 & 0.33 & 1.03 \\
\hline TANZANIA & 98.48 & 96.62 & 96.51 & 98.95 & 98.66 & 98.63 & 98.46 & 99.23 & 98.26 & 92.72 & 96.52 \\
\hline THAILAND & 5.98 & 4.76 & 1.34 & 0.98 & 1.88 & 3.79 & 3.60 & 2.80 & 2.36 & 1.26 & 2.27 \\
\hline TRINIDAD AND TOBAGO & 66.81 & 75.77 & 65.07 & 60.57 & 65.62 & 3.96 & 4.48 & 13.12 & 7.38 & 1.21 & 1.67 \\
\hline TUNISIA & 7.39 & 4.77 & 2.18 & 1.71 & 1.63 & 2.94 & 2.79 & 3.78 & 2.50 & 1.20 & 3.09 \\
\hline TURKEY & 16.49 & 7.55 & 1.53 & 1.94 & 5.46 & 9.11 & 10.82 & 20.44 & 14.36 & 7.91 & 14.35 \\
\hline UGANDA & 93.78 & 97.70 & 95.60 & 87.88 & 72.84 & 84.86 & 82.43 & 89.67 & 82.15 & 75.57 & 88.36 \\
\hline UKRAINE & & & & & & & & & 88.95 & 3.82 & 96.69 \\
\hline UNITED ARAB EMIRATES & & 2.05 & 0.49 & 0.30 & 1.41 & 1.32 & 0.97 & 1.37 & 3.09 & 1.18 & 1.02 \\
\hline URUGUAY & 86.32 & 76.73 & 47.82 & 45.14 & 57.29 & 3.67 & 2.80 & 3.33 & 1.76 & 1.02 & 2.69 \\
\hline VENEZUELA & 74.70 & 69.65 & 65.15 & 67.41 & 5.67 & 7.29 & 5.36 & 7.76 & 10.71 & 5.98 & 9.82 \\
\hline VIET NAM & 99.91 & 99.91 & 99.99 & 100.00 & 99.99 & 100.00 & 100.00 & 100.00 & 99.83 & 99.78 & 99.94 \\
\hline YEMEN & & & 99.80 & 100.00 & 100.00 & 99.51 & 98.30 & 99.60 & 91.18 & 93.72 & 77.69 \\
\hline YUGOSLAVIA & & & & & & & 99.98 & 99.99 & 99.99 & 99.99 & 100.00 \\
\hline ZAMBIA & 99.65 & 98.85 & 98.19 & 97.70 & 93.73 & 94.36 & 91.37 & 94.63 & 92.76 & 93.94 & 85.53 \\
\hline ZIMBABWE & 7.39 & 4.31 & 3.68 & 1.67 & 2.97 & 5.62 & 7.32 & 17.83 & 15.16 & 10.13 & 25.68 \\
\hline
\end{tabular}


Table 6: Out-of-Sample Performance of Model 3 in 1997

(Testing predicted default probabilities in 1997 vs. actual defaults over period 1997-1999)

\begin{tabular}{|c|c|c|c|c|c|c|c|c|}
\hline$(1)$ & $\begin{array}{c}\text { Predicted } \\
\text { DP in } 1997 \\
(2)\end{array}$ & $\begin{array}{c}\text { Effective } \\
\text { Defaults in } \\
1997, \\
1998, \text { or } \\
1999 \\
(3) \\
\end{array}$ & (4) & (5) & $\begin{array}{c}\text { False } \\
\text { alarms } \\
\\
(6)\end{array}$ & $\begin{array}{c}\begin{array}{c}\text { Not } \\
\text { predicted } \\
\text { defaults }\end{array} \\
(7) \\
\end{array}$ & $\begin{array}{c}\text { Correct } \\
\text { predic- } \\
\text { tions } \\
\\
(8)\end{array}$ & $\begin{array}{c}\text { In \% } \\
(9) \\
\end{array}$ \\
\hline ALGERIA & 69.26 & 1 & 1 & 0 & 0 & 0 & 1 & \\
\hline ANGOLA & 99.99 & 1 & 1 & 0 & 0 & 0 & 1 & \\
\hline ARGENTINA & 23.47 & 0 & 0 & 1 & 0 & 0 & 1 & \\
\hline BAHRAIN & 5.30 & 0 & 0 & 1 & 0 & 0 & 1 & \\
\hline BANGLADESH & 4.46 & 0 & 0 & 1 & 0 & 0 & 1 & \\
\hline BOLIVIA & 76.00 & 1 & 1 & 0 & 0 & 0 & 1 & \\
\hline BOTSWANA & 0.86 & 0 & 0 & 1 & 0 & 0 & 1 & \\
\hline BRAZIL & 80.08 & 0 & 1 & 0 & 1 & 0 & 0 & \\
\hline BULGARIA & 99.97 & 1 & 1 & 0 & 0 & 0 & 1 & \\
\hline CAMEROON & 92.80 & 1 & 1 & 0 & 0 & 0 & 1 & \\
\hline CHILE & 2.27 & 0 & 0 & 1 & 0 & 0 & 1 & \\
\hline CHINA & 3.48 & 0 & 0 & 1 & 0 & 0 & 1 & \\
\hline COLOMBIA & 11.42 & 0 & 0 & 1 & 0 & 0 & 1 & \\
\hline COSTA RICA & 2.50 & 0 & 0 & 1 & 0 & 0 & 1 & \\
\hline COTE D'IVOIRE & 92.64 & 1 & 1 & 0 & 0 & 0 & 1 & \\
\hline CYPRUS & 3.06 & 0 & 0 & 1 & 0 & 0 & 1 & \\
\hline CZECH REPUBLIC & 3.46 & 0 & 0 & 1 & 0 & 0 & 1 & \\
\hline DOMINICAN REPUBLIC & 88.97 & 1 & 1 & 0 & 0 & 0 & 1 & \\
\hline ECUADOR & 83.84 & 1 & 1 & 0 & 0 & 0 & 1 & \\
\hline EGYPT & 3.36 & 0 & 0 & 1 & 0 & 0 & 1 & \\
\hline EL SALVADOR & 2.36 & 0 & 0 & 1 & 0 & 0 & 1 & \\
\hline GABON & 74.25 & 1 & 1 & 0 & 0 & 0 & 1 & \\
\hline GHANA & 11.42 & 0 & 0 & 1 & 0 & 0 & 1 & \\
\hline GUATEMALA & 86.71 & 0 & 1 & 0 & 1 & 0 & 0 & \\
\hline HONDURAS & 9.62 & 1 & 0 & 1 & 0 & 1 & 0 & \\
\hline HONG KONG & 1.96 & 0 & 0 & 1 & 0 & 0 & 1 & \\
\hline HUNGARY & 3.09 & 0 & 0 & 1 & 0 & 0 & 1 & \\
\hline INDIA & 3.95 & 0 & 0 & 1 & 0 & 0 & 1 & \\
\hline INDONESIA & 6.08 & 1 & 0 & 1 & 0 & 1 & 0 & \\
\hline ISRAEL & 3.45 & 0 & 0 & 1 & 0 & 0 & 1 & \\
\hline JAMAICA & 81.83 & 0 & 1 & 0 & 1 & 0 & 0 & \\
\hline JORDAN & 78.39 & 1 & 1 & 0 & 0 & 0 & 1 & \\
\hline KENYA & 8.21 & 1 & 0 & 1 & 0 & 1 & 0 & \\
\hline KOREA, REP. OF & 1.41 & 0 & 0 & 1 & 0 & 0 & 1 & \\
\hline LEBANON & 33.18 & 0 & 0 & 1 & 0 & 0 & 1 & \\
\hline LIBYA & 98.68 & 1 & 1 & 0 & 0 & 0 & 1 & \\
\hline MALAWI & 25.75 & 0 & 0 & 1 & 0 & 0 & 1 & \\
\hline MALAYSIA & 1.99 & 0 & 0 & 1 & 0 & 0 & 1 & \\
\hline MEXICO & 4.49 & 0 & 0 & 1 & 0 & 0 & 1 & \\
\hline MOROCCO & 8.15 & 0 & 0 & 1 & 0 & 0 & 1 & \\
\hline MYANMAR & 99.48 & 1 & 1 & 0 & 0 & 0 & 1 & \\
\hline NAMIBIA & 2.12 & 0 & 0 & 1 & 0 & 0 & 1 & \\
\hline NICARAGUA & 99.72 & 1 & 1 & 0 & 0 & 0 & 1 & \\
\hline NIGERIA & 98.82 & 1 & 1 & 0 & 0 & 0 & 1 & \\
\hline OMAN & 2.24 & 0 & 0 & 1 & 0 & 0 & 1 & \\
\hline PAKISTAN & 8.58 & 1 & 0 & 1 & 0 & 1 & 0 & \\
\hline PANAMA & 80.97 & 0 & 1 & 0 & 1 & 0 & 0 & \\
\hline PAPUA NEW GUINEA & 8.30 & 1 & 0 & 1 & 0 & 1 & 0 & \\
\hline PARAGUAY & 3.61 & 0 & 0 & 1 & 0 & 0 & 1 & \\
\hline PERU & 91.48 & 1 & 1 & 0 & 0 & 0 & 1 & \\
\hline PHILIPPINES & 3.84 & 0 & 0 & 1 & 0 & 0 & 1 & \\
\hline POLAND & 61.19 & 0 & 1 & 0 & 1 & 0 & 0 & \\
\hline QATAR & 25.15 & 0 & 0 & 1 & 0 & 0 & 1 & \\
\hline
\end{tabular}




\begin{tabular}{|c|c|c|c|c|c|c|c|c|}
\hline (1) & $\begin{array}{c}\text { Predicted } \\
\text { DP in } 1997 \\
\text { (2) }\end{array}$ & $\begin{array}{c}\text { Effective } \\
\text { Defaults in } \\
1997, \\
1998 \text {, or } \\
1999 \\
(3)\end{array}$ & (4) & (5) & $\begin{array}{c}\begin{array}{c}\text { False } \\
\text { alarms }\end{array} \\
(6)\end{array}$ & $\begin{array}{c}\text { Not } \\
\begin{array}{c}\text { predicted } \\
\text { defaults }\end{array} \\
(7)\end{array}$ & $\begin{array}{l}\text { Correct } \\
\text { predic- } \\
\text { tions } \\
(8)\end{array}$ & $\begin{array}{c}\text { In \% } \\
(9)\end{array}$ \\
\hline ROMANIA & 23.93 & 0 & 0 & 1 & 0 & 0 & 1 & \\
\hline RUSSIAN FEDERATION & 99.80 & 1 & 1 & 0 & 0 & 0 & 1 & \\
\hline SAUDI ARABIA & 3.79 & 0 & 0 & 1 & 0 & 0 & 1 & \\
\hline SENEGAL & 74.37 & 1 & 1 & 0 & 0 & 0 & 1 & \\
\hline SINGAPORE & 0.24 & 0 & 0 & 1 & 0 & 0 & 1 & \\
\hline SLOVAKIA & 7.46 & 0 & 0 & 1 & 0 & 0 & 1 & \\
\hline SOUTH AFRICA & 3.93 & 0 & 0 & 1 & 0 & 0 & 1 & \\
\hline SRI LANKA & 79.03 & 0 & 1 & 0 & 1 & 0 & 0 & \\
\hline SUDAN & 99.99 & 1 & 1 & 0 & 0 & 0 & 1 & \\
\hline SYRIAN ARAB REPUBLIC & 98.21 & 1 & 1 & 0 & 0 & 0 & 1 & \\
\hline TAIWAN & 0.94 & 0 & 0 & 1 & 0 & 0 & 1 & \\
\hline TANZANIA & 99.23 & 1 & 1 & 0 & 0 & 0 & 1 & \\
\hline THAILAND & 2.80 & 0 & 0 & 1 & 0 & 0 & 1 & \\
\hline TRINIDAD AND TOBAGO & 13.12 & 0 & 0 & 1 & 0 & 0 & 1 & \\
\hline TUNISIA & 3.78 & 0 & 0 & 1 & 0 & 0 & 1 & \\
\hline TURKEY & 20.44 & 0 & 0 & 1 & 0 & 0 & 1 & \\
\hline UGANDA & 89.67 & 1 & 1 & 0 & 0 & 0 & 1 & \\
\hline UNITED ARAB EMIRATES & 1.37 & 0 & 0 & 1 & 0 & 0 & 1 & \\
\hline URUGUAY & 3.33 & 0 & 0 & 1 & 0 & 0 & 1 & \\
\hline VENEZUELA & 7.76 & 0 & 0 & 1 & 0 & 0 & 1 & \\
\hline VIET NAM & 100.00 & 1 & 1 & 0 & 0 & 0 & 1 & \\
\hline YEMEN & 99.60 & 1 & 1 & 0 & 0 & 0 & 1 & \\
\hline YUGOSLAVIA & 99.99 & 1 & 1 & 0 & 0 & 0 & 1 & \\
\hline ZAMBIA & 94.63 & 1 & 1 & 0 & 0 & 0 & 1 & \\
\hline ZIMBABWE & 17.83 & 0 & 0 & 1 & 0 & 0 & 1 & \\
\hline \# of countries & 78 & & & & & & & \\
\hline \# of defaults in 97-99 & & 30 & & & & & & \\
\hline \# of non-defaults in 97-99 & & 48 & & & & & & \\
\hline \# of predicted defaults & & & 31 & & & & & \\
\hline \# of predicted non-defaults & & & & 47 & & & & \\
\hline \# of false alarms (type II errors) & & & & & 6 & & & 12.5 \\
\hline \# of defaults not predicted (type I errors) & & & & & & 5 & & 16.7 \\
\hline \# of correct predictions & & & & & & & 67 & 85.9 \\
\hline
\end{tabular}


Table 7: Out-of-Sample Performance of Model 3 in 1998

(Testing predicted default probabilities in 1998 vs. actual defaults over period 1998-2000)

\begin{tabular}{|c|c|c|c|c|c|c|c|c|}
\hline (1) & $\begin{array}{c}\text { Predicted } \\
\text { DP in } 1998 \\
\text { (2) }\end{array}$ & $\begin{array}{c}\text { Effective } \\
\text { Defaults in } \\
1998,1999 \text {, or } \\
2000 \\
\text { (3) }\end{array}$ & $\begin{array}{c}\mathrm{DP}>50 \% \\
(4)\end{array}$ & $\begin{array}{c}\mathrm{DP}<50 \% \\
(5)\end{array}$ & $\begin{array}{c}\begin{array}{c}\text { False } \\
\text { alarms }\end{array} \\
(6)\end{array}$ & $\begin{array}{c}\text { Not } \\
\text { predicted } \\
\text { defaults } \\
\text { (7) }\end{array}$ & $\begin{array}{c}\text { Correct } \\
\text { predic- } \\
\text { tions } \\
\text { (8) }\end{array}$ & $\begin{array}{c}\text { In \% } \\
(9)\end{array}$ \\
\hline ALGERIA & 81.52 & 0 & 1 & 0 & 1 & 0 & 0 & \\
\hline ANGOLA & 99.99 & 1 & 1 & 0 & 0 & 0 & 1 & \\
\hline ARGENTINA & 16.64 & 0 & 0 & 1 & 0 & 0 & 1 & \\
\hline AZERBAIJAN & 99.65 & 1 & 1 & 0 & 0 & 0 & 1 & \\
\hline BAHRAIN & 9.21 & 0 & 0 & 1 & 0 & 0 & 1 & \\
\hline BANGLADESH & 2.92 & 0 & 0 & 1 & 0 & 0 & 1 & \\
\hline BOLIVIA & 66.24 & 1 & 1 & 0 & 0 & 0 & 1 & \\
\hline BOTSWANA & 0.96 & 0 & 0 & 1 & 0 & 0 & 1 & \\
\hline BRAZIL & 4.07 & 0 & 0 & 1 & 0 & 0 & 1 & \\
\hline BULGARIA & 73.64 & 0 & 1 & 0 & 1 & 0 & 0 & \\
\hline CAMEROON & 82.33 & 1 & 1 & 0 & 0 & 0 & 1 & \\
\hline CHILE & 1.66 & 0 & 0 & 1 & 0 & 0 & 1 & \\
\hline CHINA & 3.48 & 0 & 0 & 1 & 0 & 0 & 1 & \\
\hline COLOMBIA & 8.60 & 0 & 0 & 1 & 0 & 0 & 1 & \\
\hline COSTA RICA & 1.45 & 0 & 0 & 1 & 0 & 0 & 1 & \\
\hline COTE D'IVOIRE & 71.13 & 1 & 1 & 0 & 0 & 0 & 1 & \\
\hline CROATIA & 88.82 & 0 & 1 & 0 & 1 & 0 & 0 & \\
\hline CYPRUS & 2.58 & 0 & 0 & 1 & 0 & 0 & 1 & \\
\hline CZECH REPUBLIC & 1.57 & 0 & 0 & 1 & 0 & 0 & 1 & \\
\hline DOMINICAN REPUBLIC & 75.92 & 0 & 1 & 0 & 1 & 0 & 0 & \\
\hline ECUADOR & 85.55 & 1 & 1 & 0 & 0 & 0 & 1 & \\
\hline EGYPT & 2.51 & 0 & 0 & 1 & 0 & 0 & 1 & \\
\hline EL SALVADOR & 1.32 & 0 & 0 & 1 & 0 & 0 & 1 & \\
\hline ESTONIA & 7.98 & 0 & 0 & 1 & 0 & 0 & 1 & \\
\hline GABON & 88.30 & 1 & 1 & 0 & 0 & 0 & 1 & \\
\hline GHANA & 8.33 & 0 & 0 & 1 & 0 & 0 & 1 & \\
\hline GUATEMALA & 7.30 & 0 & 0 & 1 & 0 & 0 & 1 & \\
\hline HONDURAS & 77.93 & 1 & 1 & 0 & 0 & 0 & 1 & \\
\hline HONG KONG & 2.12 & 0 & 0 & 1 & 0 & 0 & 1 & \\
\hline HUNGARY & 1.42 & 0 & 0 & 1 & 0 & 0 & 1 & \\
\hline INDIA & 2.90 & 0 & 0 & 1 & 0 & 0 & 1 & \\
\hline INDONESIA & 95.02 & 1 & 1 & 0 & 0 & 0 & 1 & \\
\hline ISRAEL & 1.72 & 0 & 0 & 1 & 0 & 0 & 1 & \\
\hline JAMAICA & 68.38 & 0 & 1 & 0 & 1 & 0 & 0 & \\
\hline JORDAN & 67.89 & 1 & 1 & 0 & 0 & 0 & 1 & \\
\hline KAZAKHSTAN & 7.38 & 1 & 0 & 1 & 0 & 1 & 0 & \\
\hline KENYA & 7.35 & 1 & 0 & 1 & 0 & 1 & 0 & \\
\hline KOREA, REP. OF & 1.47 & 0 & 0 & 1 & 0 & 0 & 1 & \\
\hline LATVIA & 21.76 & 0 & 0 & 1 & 0 & 0 & 1 & \\
\hline LEBANON & 9.47 & 0 & 0 & 1 & 0 & 0 & 1 & \\
\hline LIBYA & 99.31 & 1 & 1 & 0 & 0 & 0 & 1 & \\
\hline LITHUANIA & 14.36 & 0 & 0 & 1 & 0 & 0 & 1 & \\
\hline MALAWI & 8.14 & 0 & 0 & 1 & 0 & 0 & 1 & \\
\hline MALAYSIA & 1.06 & 0 & 0 & 1 & 0 & 0 & 1 & \\
\hline MEXICO & 3.17 & 0 & 0 & 1 & 0 & 0 & 1 & \\
\hline MOLDOVA & 97.99 & 1 & 1 & 0 & 0 & 0 & 1 & \\
\hline MOROCCO & 4.97 & 0 & 0 & 1 & 0 & 0 & 1 & \\
\hline MYANMAR & 75.24 & 1 & 1 & 0 & 0 & 0 & 1 & \\
\hline NAMIBIA & 0.90 & 0 & 0 & 1 & 0 & 0 & 1 & \\
\hline NICARAGUA & 99.21 & 1 & 1 & 0 & 0 & 0 & 1 & \\
\hline NIGERIA & 99.54 & 1 & 1 & 0 & 0 & 0 & 1 & \\
\hline OMAN & 7.07 & 0 & 0 & 1 & 0 & 0 & 1 & \\
\hline PAKISTAN & 8.19 & 1 & 0 & 1 & 0 & 1 & 0 & \\
\hline PANAMA & 4.68 & 0 & 0 & 1 & 0 & 0 & 1 & \\
\hline PAPUA NEW GUINEA & 6.19 & 1 & 0 & 1 & 0 & 1 & 0 & \\
\hline PARAGUAY & 2.72 & 0 & 0 & 1 & 0 & 0 & 1 & \\
\hline PERU & 84.83 & 0 & 1 & 0 & 1 & 0 & 0 & \\
\hline
\end{tabular}




\begin{tabular}{|c|c|c|c|c|c|c|c|c|}
\hline (1) & $\begin{array}{c}\text { Predicted } \\
\text { DP in } 1998 \\
\text { (2) }\end{array}$ & $\begin{array}{c}\text { Effective } \\
\text { Defaults in } \\
1998,1999 \text {, or } \\
2000 \\
\text { (3) }\end{array}$ & $\begin{array}{c}\mathrm{DP}>50 \% \\
(4)\end{array}$ & $\begin{array}{c}\mathrm{DP}<50 \% \\
(5)\end{array}$ & $\begin{array}{c}\text { False } \\
\text { alarms } \\
(6)\end{array}$ & $\begin{array}{c}\text { Not } \\
\text { predicted } \\
\text { defaults }\end{array}$ & $\begin{array}{c}\text { Correct } \\
\text { predic- } \\
\text { tions } \\
\\
(8)\end{array}$ & $\begin{array}{l}\text { In \% } \\
\text { (9) }\end{array}$ \\
\hline PHILIPPINES & 1.41 & 0 & 0 & 1 & 0 & 0 & 1 & \\
\hline POLAND & 1.09 & 0 & 0 & 1 & 0 & 0 & 1 & \\
\hline QATAR & 8.49 & 0 & 0 & 1 & 0 & 0 & 1 & \\
\hline ROMANIA & 8.41 & 0 & 0 & 1 & 0 & 0 & 1 & \\
\hline RUSSIAN FEDERATION & 97.14 & 1 & 1 & 0 & 0 & 0 & 1 & \\
\hline SAUDI ARABIA & 5.23 & 0 & 0 & 1 & 0 & 0 & 1 & \\
\hline SENEGAL & 65.92 & 1 & 1 & 0 & 0 & 0 & 1 & \\
\hline SINGAPORE & 0.11 & 0 & 0 & 1 & 0 & 0 & 1 & \\
\hline SLOVAKIA & 3.79 & 0 & 0 & 1 & 0 & 0 & 1 & \\
\hline SLOVENIA & 1.35 & 0 & 0 & 1 & 0 & 0 & 1 & \\
\hline SOUTH AFRICA & 2.75 & 0 & 0 & 1 & 0 & 0 & 1 & \\
\hline SRI LANKA & 65.74 & 0 & 1 & 0 & 1 & 0 & 0 & \\
\hline SUDAN & 99.98 & 1 & 1 & 0 & 0 & 0 & 1 & \\
\hline SYRIAN ARAB REPUBLIC & 98.58 & 1 & 1 & 0 & 0 & 0 & 1 & \\
\hline TAIWAN & 0.75 & 0 & 0 & 1 & 0 & 0 & 1 & \\
\hline TANZANIA & 98.26 & 1 & 1 & 0 & 0 & 0 & 1 & \\
\hline THAILAND & 2.36 & 0 & 0 & 1 & 0 & 0 & 1 & \\
\hline TRINIDAD AND TOBAGO & 7.38 & 0 & 0 & 1 & 0 & 0 & 1 & \\
\hline TUNISIA & 2.50 & 0 & 0 & 1 & 0 & 0 & 1 & \\
\hline TURKEY & 14.36 & 0 & 0 & 1 & 0 & 0 & 1 & \\
\hline UGANDA & 82.15 & 1 & 1 & 0 & 0 & 0 & 1 & \\
\hline UKRAINE & 88.95 & 1 & 1 & 0 & 0 & 0 & 1 & \\
\hline UNITED ARAB EMIRATES & 3.09 & 0 & 0 & 1 & 0 & 0 & 1 & \\
\hline URUGUAY & 1.76 & 0 & 0 & 1 & 0 & 0 & 1 & \\
\hline VENEZUELA & 10.71 & 0 & 0 & 1 & 0 & 0 & 1 & \\
\hline VIET NAM & 99.83 & 1 & 1 & 0 & 0 & 0 & 1 & \\
\hline YEMEN & 91.18 & 1 & 1 & 0 & 0 & 0 & 1 & \\
\hline YUGOSLAVIA & 99.99 & 1 & 1 & 0 & 0 & 0 & 1 & \\
\hline ZAMBIA & 92.76 & 1 & 1 & 0 & 0 & 0 & 1 & \\
\hline ZIMBABWE & 15.16 & 1 & 0 & 1 & 0 & 1 & 0 & \\
\hline \# of countries & 87 & & & & & & & \\
\hline \# of defaults in $99-00$ & & 31 & & & & & & \\
\hline \# of non-defaults in $98-00$ & & 56 & & & & & & \\
\hline \# of predicted defaults & & & 33 & & & & & \\
\hline \# of predicted non-defaults & & & & 54 & & & & \\
\hline \# of false alarms (type II errors) & & & & & 7 & & & 12.5 \\
\hline \# of defaults not predicted (type I errors) & & & & & & 5 & & 16.1 \\
\hline \# of correct predictions & & & & & & & 75 & 86.2 \\
\hline
\end{tabular}


Table 8: Average 3-Year Cumulative Default Rates by Letter Rating, Moody's Investors Service and Standard \& Poor's

\begin{tabular}{|c|c|c|c|}
\hline $\begin{array}{c}\text { Moody's } \\
\text { Ratings }\end{array}$ & $\begin{array}{c}\text { Moody's } \\
\text { Average } \\
\text { 3-Year Cumulative Default Rates }\end{array}$ & $\begin{array}{c}\text { Standard \& Poor's } \\
\text { Ratings }\end{array}$ & $\begin{array}{c}\text { Standard \&Poor's } \\
\text { Average }\end{array}$ \\
3aa & $0.00 \%$ & AAA & $0.05 \%$ \\
Aa1 & $0.00 \%$ & AA+ & $0.00 \%$ \\
Aa2 & $0.06 \%$ & AA & $0.00 \%$ \\
Aa3 & $0.19 \%$ & AA- & $0.18 \%$ \\
A1 & $0.33 \%$ & A+ & $0.16 \%$ \\
A2 & $0.14 \%$ & A & $0.14 \%$ \\
A3 & $0.25 \%$ & A- & $0.35 \%$ \\
Baa1 & $0.52 \%$ & BBB+ & $0.59 \%$ \\
Baa2 & $0.60 \%$ & BBB & $0.71 \%$ \\
Baa3 & $1.34 \%$ & BBB- & $0.99 \%$ \\
Ba1 & $3.86 \%$ & BB+ & $3.15 \%$ \\
Ba2 & $5.05 \%$ & BB & $4.13 \%$ \\
Ba3 & $11.89 \%$ & BB- & $6.79 \%$ \\
B1 & $14.81 \%$ & B+ & $10.43 \%$ \\
B2 & $20.28 \%$ & B & $20.41 \%$ \\
B3 & $27.27 \%$ & B- & $22.37 \%$ \\
Caa1-C & $34.23 \%$ & CCC-C & $33.11 \%$ \\
\hline
\end{tabular}

\section{Sources and Notes:}

For Moody's ratings, the corresponding default rates are calculated on the basis of the credit experiences that 15'700 companies and sovereigns rated by Moody's made on their publicly issued senior unsecured long-term bonds between 1919 and the end of 1999 (See Moody's Investors Service (2000), pp. 8-10 \& 27).

For Standard \& Poor's ratings, the corresponding default rates are calculated on the basis of the credit experiences that the 7300 corporate holders of S\&P's long-term issuer ratings made between 1981 and the end of 1997 (See Standard \& Poor's (1999a), pp. 10-15). 


\section{Table 9: Model 3 Default Probabilities vs. Rating Agencies' Default Rates before Asian Crisis}

(40 emerging markets rated by either Moody's or S\&P's at end 1996)

\begin{tabular}{|c|c|c|c|c|c|}
\hline & \multicolumn{3}{|c|}{ 3-Year Cumulative Default Probability / Rate } & \multicolumn{2}{|c|}{$\begin{array}{c}\text { Ratings Jan 1, } 1997 \\
\text { (Long-term Sovereign FX) }\end{array}$} \\
\hline & $\begin{array}{c}\text { Model } 3 \text { DP in } \\
1996\end{array}$ & Moody's DR & S\&P'S DR & Moody's & S\&P's \\
\hline ARGENTINA & 91.76 & 14.81 & 6.79 & B1 & BB- \\
\hline BAHRAIN & 2.50 & 3.86 & -- & $\mathrm{Ba} 1$ & -- \\
\hline BRAZIL & 81.75 & 14.81 & 10.43 & B1 & $\mathrm{B}+$ \\
\hline BULGARIA & 86.88 & 27.27 & -- & B3 & -- \\
\hline CHILE & 1.71 & 0.52 & 0.35 & Baa1 & A- \\
\hline CHINA & 3.22 & 0.25 & 0.71 & $\mathrm{~A} 3$ & BBB \\
\hline COLOMBIA & 4.17 & 1.34 & 0.99 & Baa3 & BBB- \\
\hline CYPRUS & 2.44 & 0.14 & 0.18 & $\mathrm{~A} 2$ & AA- \\
\hline CZECH REPUBLIC & 3.10 & 0.52 & 0.14 & Baa1 & $A$ \\
\hline EGYPT & 2.07 & 5.05 & -- & $\mathrm{Ba} 2$ & -- \\
\hline EL SALVADOR & 57.36 & -- & 4.13 & -- & BB \\
\hline HONG KONG & 1.08 & 0.25 & 0.14 & $\mathrm{~A} 3$ & $A$ \\
\hline HUNGARY & 2.47 & 1.34 & 0.99 & Baa3 & BBB- \\
\hline INDIA & 2.93 & 1.34 & -- & Baa3 & -- \\
\hline INDONESIA & 5.84 & 1.34 & 0.71 & Baa3 & BBB \\
\hline ISRAEL & 2.99 & 0.25 & 0.35 & $\mathrm{~A} 3$ & A- \\
\hline JORDAN & 75.20 & 11.89 & 6.79 & Ba3 & BB- \\
\hline KOREA, REP. OF & 1.49 & 0.33 & 0.18 & $\mathrm{~A} 1$ & AA- \\
\hline MALAYSIA & 1.73 & 0.33 & 0.16 & $\mathrm{~A} 1$ & $A+$ \\
\hline MEXICO & 4.42 & 5.05 & 4.13 & $\mathrm{Ba} 2$ & BB \\
\hline OMAN & 1.74 & 0.60 & 0.99 & Baa2 & BBB- \\
\hline PAKISTAN & 13.12 & -- & 10.43 & -- & $\mathrm{B}_{+}$ \\
\hline PARAGUAY & 2.80 & -- & 6.79 & -- & BB- \\
\hline PERU & 97.81 & 20.28 & -- & B2 & -- \\
\hline PHILIPPINES & 4.43 & 5.05 & 6.79 & $\mathrm{Ba} 2$ & BB- \\
\hline POLAND & 60.86 & 1.34 & 0.99 & Baa3 & BBB- \\
\hline QATAR & 10.88 & 0.6 & 0.71 & Baa2 & BBB \\
\hline ROMANIA & 6.84 & 11.89 & 6.79 & Ba3 & BB- \\
\hline RUSSIAN FEDERATION & 99.69 & 5.05 & 6.79 & $\mathrm{Ba} 2$ & BB- \\
\hline SAUDI ARABIA & 2.47 & 1.34 & -- & Baa3 & -- \\
\hline SINGAPORE & 0.22 & 0.00 & 0.05 & Aa1 & AAA \\
\hline SLOVAKIA & 5.67 & 1.34 & 0.99 & Baa3 & BBB- \\
\hline TAIWAN & 0.70 & 0.19 & 0.00 & Aa3 & $\mathrm{AA}+$ \\
\hline THAILAND & 3.60 & 0.14 & 0.14 & $\mathrm{~A} 2$ & $A$ \\
\hline TRINIDAD AND TOBAGO & 4.48 & 3.86 & 3.15 & $\mathrm{Ba} 1$ & $\mathrm{BB}+$ \\
\hline TUNISIA & 2.79 & 1.34 & -- & Baa3 & -- \\
\hline TURKEY & 10.82 & 11.89 & 20.41 & $\mathrm{Ba3}$ & B \\
\hline UNITED ARAB EMIRATES & 0.97 & 0.52 & -- & Baa1 & -- \\
\hline URUGUAY & 2.80 & 3.86 & 3.15 & $\mathrm{Ba1}$ & $\mathrm{BB}+$ \\
\hline VENEZUELA & 5.36 & 5.05 & 20.41 & $\mathrm{Ba} 2$ & $B$ \\
\hline
\end{tabular}

Notes:

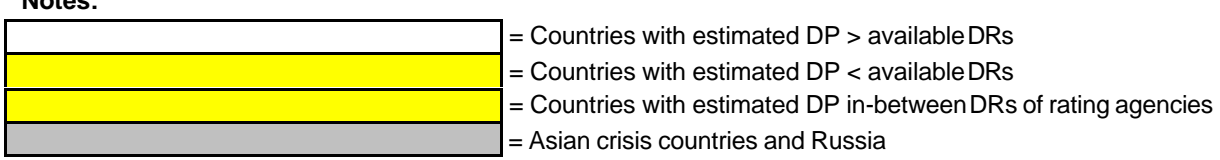




\section{Table 10: Model 3 Default Probabilities vs. Rating Agencies' Default Rates at Beginning of 2001}

(25 emerging markets with largest liabilities towards BIS reporting banks in 2000)

\begin{tabular}{|c|c|c|c|c|c|c|c|}
\hline & \multicolumn{3}{|c|}{$\begin{array}{c}\text { 3-Year Cumulative Default Probability / } \\
\text { Rate }\end{array}$} & \multicolumn{2}{|c|}{$\begin{array}{l}\text { Ratings Jan 1, } 2001 \text { (Long- } \\
\text { term Sovereign FX) }\end{array}$} & \multicolumn{2}{|c|}{ Memo items } \\
\hline & $\begin{array}{l}\text { Model } 3 \text { DP } \\
\text { in } 2000\end{array}$ & Moody's DR & S\&P's DR & Moody's & S\&P's & $\begin{array}{l}\text { Liabilities } \\
\text { towards BIS } \\
\text { reporting banks } \\
\text { (US\$bn) }\end{array}$ & $\begin{array}{c}\text { Liabilities } \\
\text { towards BIS } \\
\text { banks / GDP } \\
\text { (in \%) }\end{array}$ \\
\hline ARGENTINA & 18.15 & 14.81 & 6.79 & B1 & BB- & $67.0^{*}$ & 23.5 \\
\hline BRAZIL & 7.21 & 14.81 & 6.79 & B1 & BB- & 67.7 & 10.8 \\
\hline CHILE & 2.48 & 0.52 & 0.35 & Baa1 & A- & 22.3 & 31.7 \\
\hline CHINA & 6.13 & 0.25 & 0.71 & A3 & BBB & 58.3 & 5.3 \\
\hline COLOMBIA & 8.48 & 5.05 & 4.13 & $\mathrm{Ba} 2$ & BB & 11.6 & 14.2 \\
\hline CZECH REPUBLIC & 2.71 & 0.52 & 0.35 & Baa1 & A- & 11.4 & 22.5 \\
\hline HONG KONG & 3.28 & 0.25 & 0.14 & $\mathrm{~A} 3$ & $A$ & 110.0 & 67.4 \\
\hline HUNGARY & 2.41 & 0.25 & 0.35 & $\mathrm{~A} 3$ & A- & 16.9 & 37.1 \\
\hline INDIA & 4.26 & 5.05 & 4.13 & $\mathrm{Ba} 2$ & BB & 22.2 & 4.7 \\
\hline INDONESIA & 92.22 & 27.27 & 22.37 & B3 & $B-$ & 40.3 & 26.3 \\
\hline KOREA, REP. OF & 1.96 & 0.60 & 0.71 & Baa2 & BBB & 58.8 & 12.9 \\
\hline MALAYSIA & 2.24 & 0.60 & 0.71 & Baa2 & BBB & 20.9 & 23.3 \\
\hline MEXICO & 4.17 & 1.34 & 3.15 & Baa3 & $\mathrm{BB}+$ & 63.7 & 11.1 \\
\hline PANAMA $^{\star *}$ & 4.80 & 3.86 & 3.15 & $\mathrm{Ba} 1^{* * *}$ & $\mathrm{BB}+$ & 31.0 & 311.4 \\
\hline PERU & 85.62 & 11.89 & 6.79 & $\mathrm{Ba3}$ & BB- & 13.2 & 24.7 \\
\hline PHILIPPINES & 1.02 & 3.86 & 3.15 & $\mathrm{Ba} 1$ & $\mathrm{BB}+$ & 16.5 & 22.1 \\
\hline POLAND & 1.95 & 0.52 & 0.59 & Baa1 & $\mathrm{BBB}+$ & 22.2 & 14.1 \\
\hline RUSSIAN FEDERATION & 81.60 & 20.28 & 22.37 & B2 & $B-$ & 39.6 & 15.8 \\
\hline SAUDI ARABIA & 1.60 & 1.34 & -- & Baa3 & -- & 16.8 & 9.7 \\
\hline SINGAPORE ${ }^{\star \star}$ & 0.21 & 0.00 & 0.00 & Aa1 & AAA & 100.1 & 108.5 \\
\hline SOUTH AFRICA & 3.56 & 1.34 & 0.99 & Baa3 & BBB- & 18.3 & 14.5 \\
\hline TAIWAN & 1.03 & 0.19 & 0.00 & Aa3 & $\mathrm{AA}+$ & 18.1 & 5.8 \\
\hline THAILAND & 2.27 & 1.34 & 0.99 & Baa3 & BBB- & 26.7 & 21.8 \\
\hline TURKEY & 14.35 & 14.81 & 10.43 & B1 & $\mathrm{B}+$ & 47.4 & 23.3 \\
\hline VENEZUELA & 9.82 & 20.28 & 20.41 & B2 & B & 13.2 & 10.9 \\
\hline
\end{tabular}

Notes:

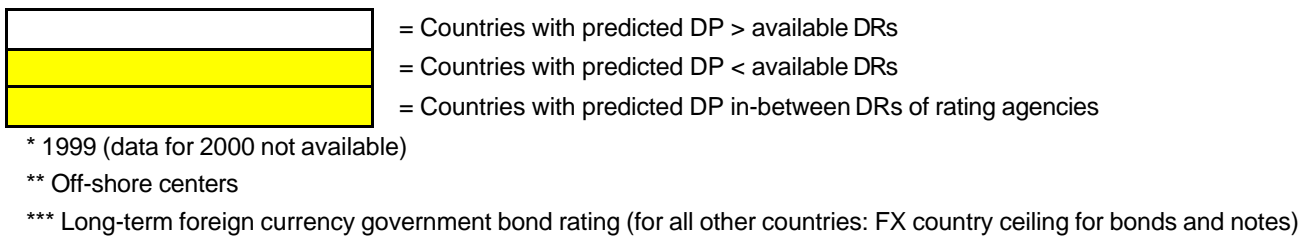

